Tabir Dal Poggetto Oliveira Sueyoshi

\title{
Aspectos jurídicos do plágio literário
}

Tese de Doutorado

Orientador: Professor Doutor Antonio Carlos Morato

Faculdade de Direito da Universidade de São Paulo 
Tabir Dal Poggetto Oliveira Sueyoshi

\section{Aspectos jurídicos do plágio literário}

Tese apresentada à Banca Examinadora da Faculdade de Direito da Universidade de São Paulo, como exigência parcial para a obtenção do título de Doutor em Direito (área de concentração Direito Civil), sob a orientação do Professor Doutor Antonio Carlos Morato.

Faculdade de Direito da Universidade de São Paulo 


\section{FOLHA DE APROVAÇÃO}

Nome: SUEYOSHI, Tabir Dal Poggetto Oliveira.

Título: Aspectos jurídicos do plágio literário.

Tese apresentada à Banca Examinadora da Faculdade de Direito da Universidade de São Paulo, como exigência parcial para a obtenção do título de Doutor em Direito (área de concentração Direito Civil), sob a orientação do Professor Doutor Antonio Carlos Morato.

Banca Examinadora 
DEDICATÓRIA

Dedico aos meus pais e ao Professor Doutor Fábio Maria De-Mattia (in memoriam). 


\section{AGRADECIMENTOS}

Agradeço a Deus Uno e Trino.

Agradeço ao Professor Doutor Antonio Carlos Morato pela orientação e amizade.

Agradeço à Professora Titular Silmara Juny de Abreu Chinellato pela sugestão do tema do presente trabalho, um tema desafiador e não muito estudado entre nós.

Registra-se também que as aulas de Direito de Autor do curso de pós-graduação stricto sensu, ministradas pelos professores Titular Silmara Juny de Abreu Chinellato e Doutor Antonio Carlos Morato, contribuíram sobremaneira para o desenvolvimento deste trabalho.

Por fim, agradeço ao amigo e antigo acadêmico Hugo Maciel de Carvalho, que conheci ainda calouro das Arcadas, pela paciente revisão deste trabalho. 


\section{RESUMO}

A tese examina o plágio, em especial literário. Para tanto, fazemos um breve exame histórico, tanto sobre o plágio como sobre o surgimento do Direito de Autor. Em seguida, fazemos uma análise legislativa no Direito brasileiro, desde o Império até nossos dias. Também examinamos as convenções internacionais sobre o Direito de Autor recepcionadas pelo ordenamento jurídico brasileiro: a Convenção de Berna, a Convenção Universal sobre o Direito de Autor e o Acordo sobre Aspectos dos Direitos de Propriedade Intelectual Relacionados ao Comércio (TRIPS/AADPIC). Para melhor compreender o plágio sob a ótica do Direito de Autor, examinamos as teorias de identificação de elementos protegidos na obra, bem como os conceitos básicos do Direito de Autor. Enfim, concluímos que o plágio é, sobretudo, uma questão de fato.

Palavras-chave: Plágio. Direito de Autor. Obra literária. Violações aos direitos do autor. 


\section{RÉSUMÉ}

Le sujet de la thése c'est le plagiat de l'œuvre littéraire. Pour examiner le sujet, on n'a fait d'abord une brève étude historique sur le plagiat à l'Antiquité aussi bien que la naissance de Droit d'Auteur. En suite, on a fait une analyse législative dans le Droit brésilien, depuis 1’Empire jusqu’à nos jours. D’autre part, nous avons aussi examiné les conventions internationales sur le Droit d'Auteur reçues par l'ordre juridique brésiliénne: la Convention de Berne, la Convention Universelle sur le Droit d'Auteur et 1'Accord Relatifs aux Aspects des Droits de la Propriété Intellectuelle qui touchent au Commerce (TRIPS/ADPIC). Pour mieux comprendre le plagiat selon le Droit d'Auteur, on a étudé les théories de l'identification des éléments protégés dans l'œuvre, aussi bien que les concepts de base de Droit d'Auteur. Enfin, nous concluons que le plagiat est surtout une question de fait.

Mots-clé: Plagiat. Droit d’Auteur. L' œuvre littéraire. Violations des droits de l’auteur. 


\section{RIASSUNTO}

Il soggetto della tesi è il plagio di opere dell'ingegno letterarie Abbiamo fatto un breve approccio storico partendo dall'Antiquità alla nascita del Diritto d'Autore. In seguito, abbiamo fatto un'analisi legislativa nel Diritto brasiliano, dall'Impero ai nostri giorni. Abbiamo studiato anche le convenzioni internazionali accolte dall'ordinamento giuridico brasiliano: la Convenzione di Berna, la Convenzione Universale sul Diritto d'Autore e 1' Accordo sugli Aspetti Commerciali dei Diritti di Proprietà Intellettuale (TRIPS). Per meglio capire il plagio secondo il Diritto d'Autore, abbiamo studiato le teorie sull' identificazione degli elementi protetti nell’opera dell'ingegno, così comme i concetti di base del Diritto d'Autore. Per finire, abbiamo concluso che il plagio è soppratutto una questione di fatto.

Parole-chiave: Plagio. Diritto d’Autore. L’opera dell'ingegno letteraria. Violazioni dei diritti d'autore. 


\section{SUMÁRIO}

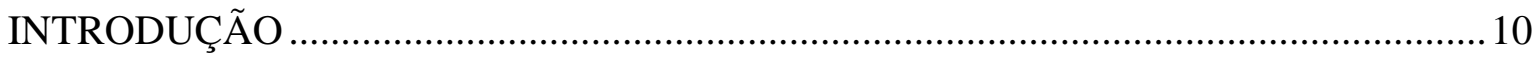

1 BREVE HISTÓRICO DO PLÁGIO LITERÁRIO E DO DIREITO DE AUTOR ...........12

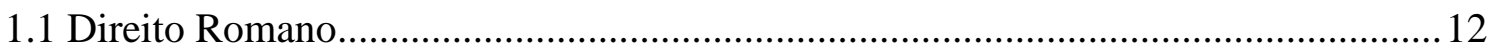

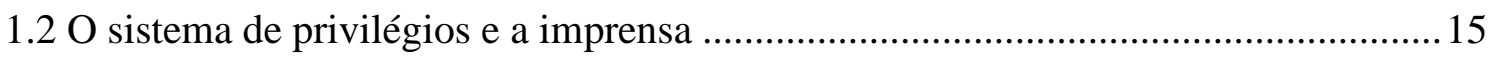

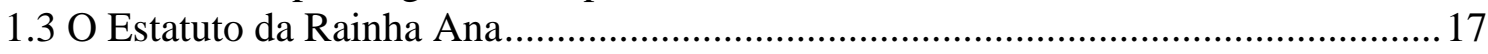

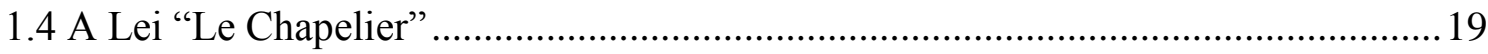

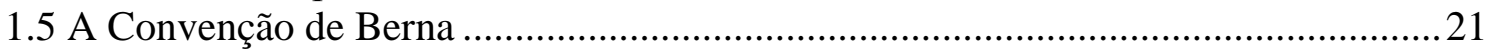

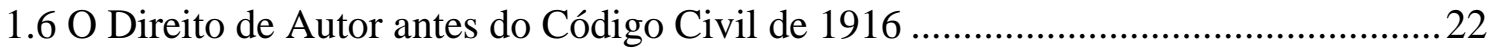

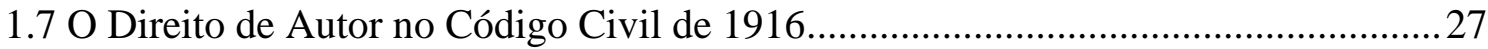

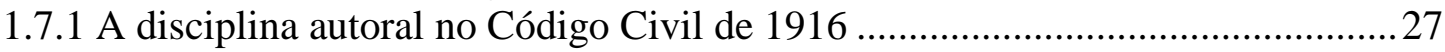

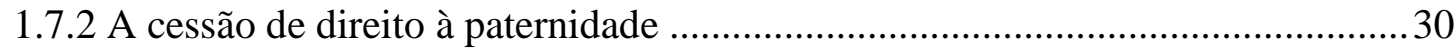

2 LEGISLAÇÃO AUTORAL BRASILEIRA: REVOGADA, VIGENTE, ANTEPROJETO

DE LEI E PROJETO DE LEI.................................................................................... 34

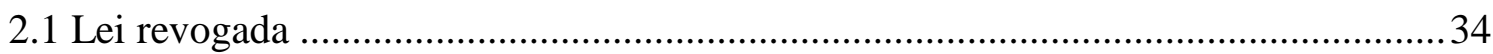

2.1.1 Lei n. 5.988/1973: Lei sobre Direitos Autorais ................................................... 34

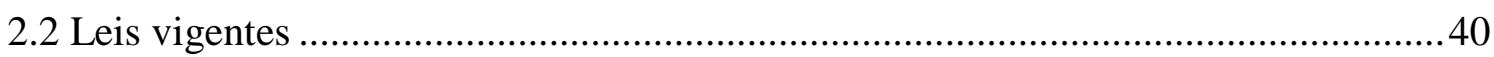

2.2.1 Código Penal brasileiro de 1940 e sucessivas alterações .................................. 40

2.2.2 Lei n. 9.610/1998: Lei sobre Direitos Autorais .......................................................45

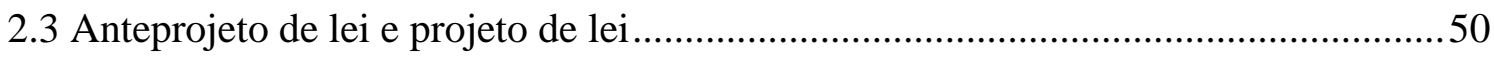

2.3.1 Anteprojeto de lei sobre Direitos Autorais ....................................................5 50

2.3.2 Projeto de Lei n. 232, de 2012: reforma do Código Penal brasileiro ...................53

3 DIREITO INTERNACIONAL E DIREITO COMPARADO..........................................62

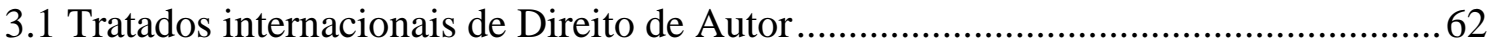

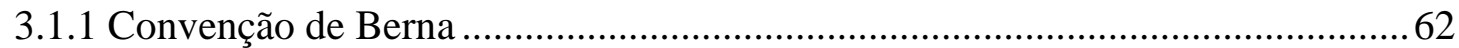

3.1.2 Convenção Universal sobre o Direito de Autor ..................................................65

3.1.3 Acordo sobre Aspectos dos Direitos de Propriedade Intelectual Relacionados ao

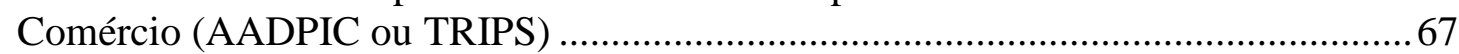

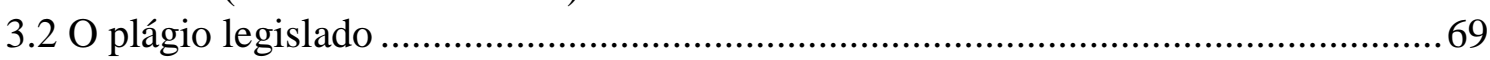

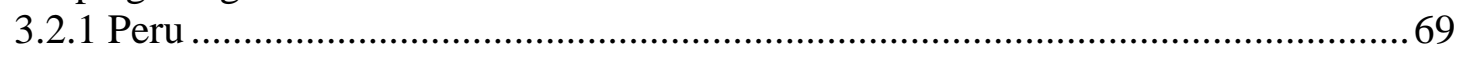

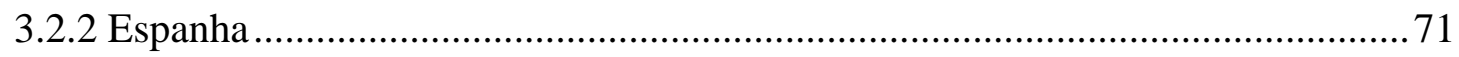

4 A IDENTIFICAÇÃO DA OBRA LITERÁRIA E REQUISITOS DE PROTEÇÃO .......73

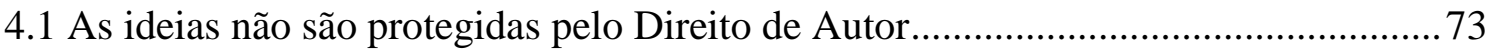

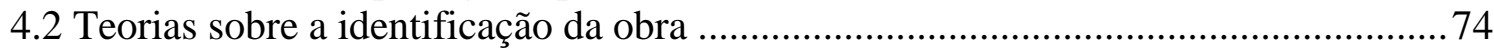

4.2.1 Teoria da forma interna, forma externa e conteúdo .......................................... 75

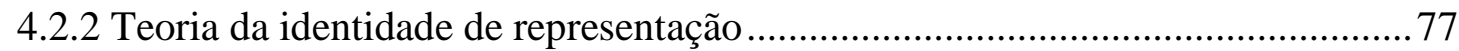

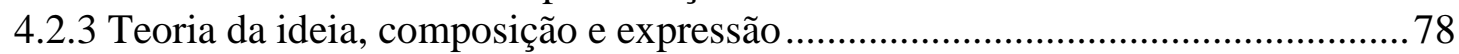

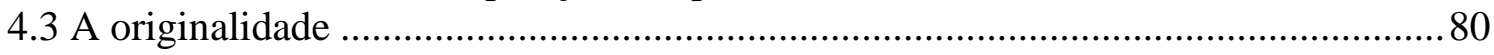

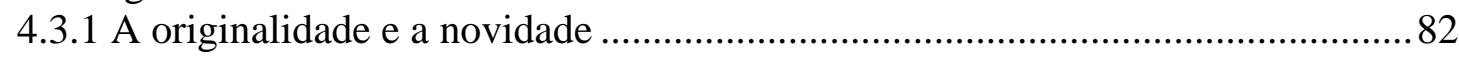

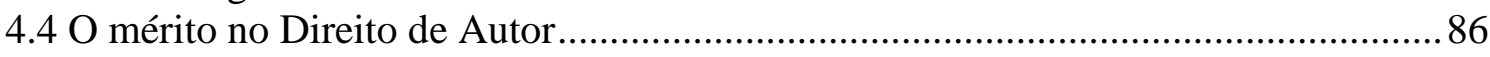

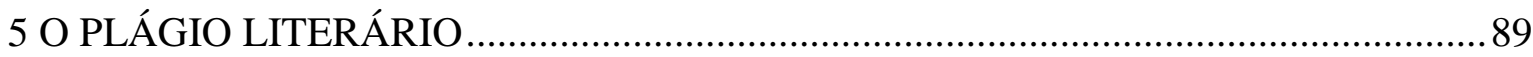

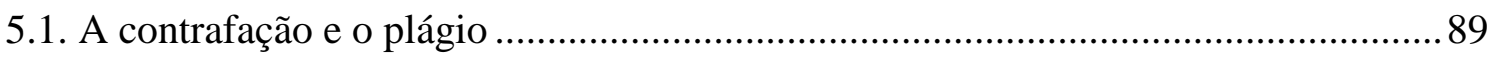

5.2 A usurpação de paternidade e a usurpação de nome ...................................................93

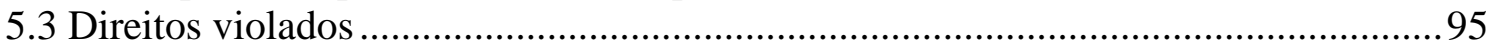

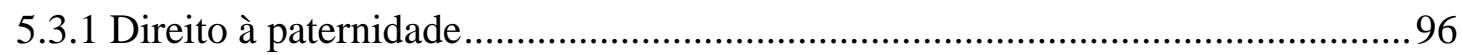

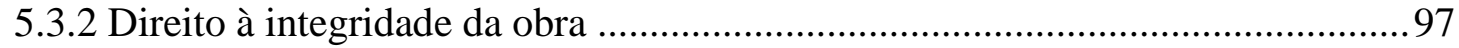

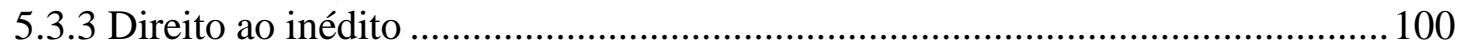


5.4 Publicação da obra como elemento do plágio ........................................................ 101

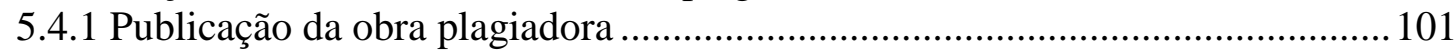

5.4.2 Negociações anteriores ao contrato de edição ................................................... 103

5.5 A identificação do plágio pelas semelhanças entre as obras.................................. 105

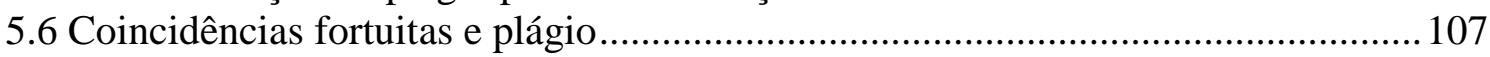

$5.7 \mathrm{O}$ "larcin imperceptible" e o plágio parcial.............................................................. 109

5.8 A proteção do título da obra, do índice e o plágio ................................................... 110

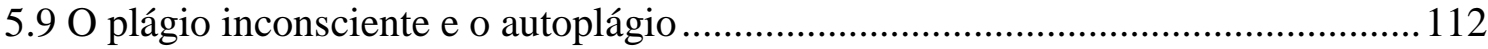

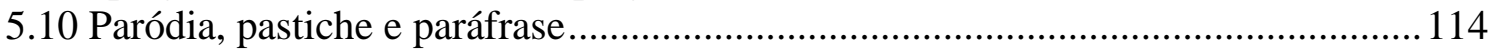

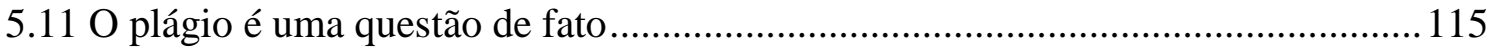

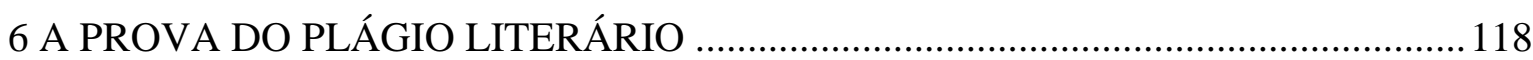

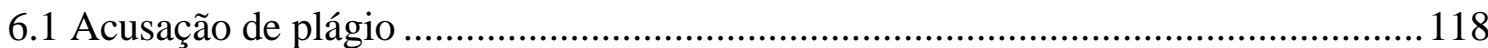

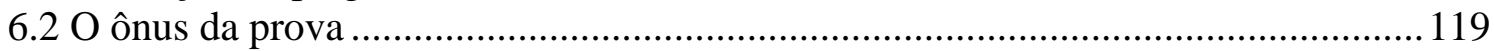

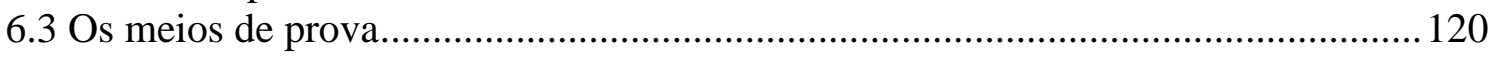

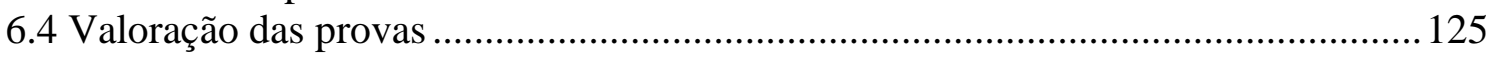

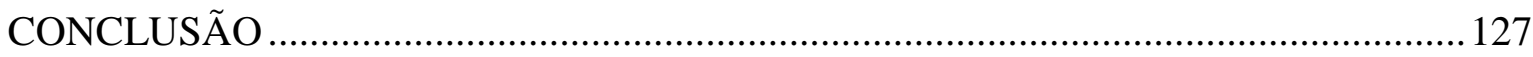

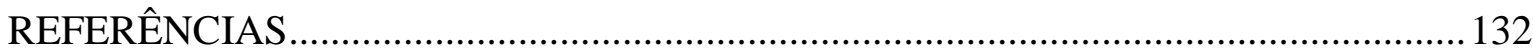




\section{INTRODUÇÃO}

O presente trabalho visa analisar o plágio literário sob a perspectiva do Direito de Autor. Trata-se de tema polêmico que enseja acusações em muitos ambientes, o que nem sempre encontra amparo jurídico.

Inicialmente fazemos um breve histórico do plágio e do Direito de Autor, partindo da Antiguidade e passando pelos marcos jurídicos da seara autoral: o Estatuto da Rainha Ana, a Lei Le Chapelier e a Convenção de Berna. Na sequência, analisamos as normas jurídicas brasileiras sobre o Direito de Autor anteriores ao Código Civil de 1916. Este diploma legal também é estudado na parte atinente ao Direito de Autor.

O segundo capítulo do trabalho é dedicada ao estudo das leis brasileiras revogada, vigentes e em elaboração. Nessa parte há o exame de leis tanto penais como autorais propriamente ditas. O estudo das normas jurídicas sobre a matéria é necessário para a compreensão legal do fenômeno do plágio, em nenhum momento legislado entre nós.

Em seguida, as convenções internacionais recepcionadas por nosso ordenamento jurídico sobre o Direito de Autor são examinadas: a Convenção de Berna, a Convenção Universal sobre o Acordo sobre Aspectos dos Direitos de Propriedade Intelectual Relacionados ao Comércio (TRIPS/AADPIC), Anexo 1C do Acordo Constitutivo da Organização Mundial de Comércio - OMC. Também examinamos a lei autoral peruana revogada, que diretamente positivou o plágio, bem como o Código Penal espanhol.

Para compreender melhor os elementos protegidos na obra pelo Direito de Autor, fazemos uma incursão nas teorias de identificação conhecidas no Direito de Autor, bem como nos conceitos básicos da matéria no escopo de tratar a questão sob a ótica jusautoralista. Nessa linha de ideias, o plágio literário é estudado dentro dos limites do Direito de Autor, sem ingressar em conceitos metajurídicos, que podem tornar o estudo de tema tão nebuloso ainda mais obscuro.

Por conseguinte, podemos adiantar que o plágio ocorre na extração de elementos criativos de obra preexistente com usurpação de paternidade, isto é, alguém se apropria 
indevidamente de elementos pessoais de obra preexistente para criar uma obra nova, suprimindo o nome do verdadeiro autor no fito de enganar o público. 


\section{BREVE HISTÓRICO DO PLÁGIO LITERÁRIO E DO DIREITO DE AUTOR}

\subsection{Direito Romano}

Na Antiguidade não havia a proteção jurídica ao autor e às suas obras como hoje, o que não quer dizer que a opinião pública não reprovasse a apropriação de criação intelectual alheia para apresentar ao público como se fosse própria.

O vocábulo plagium, na Roma antiga, designava o furto de pessoas livres, crianças e escravos para venda. Tal delito estava positivado na Lex Fabia de Plagiariis, sendo a punição, em certos casos, a pena capital. ${ }^{1}$

O poeta latino Marcial empregou de modo explícito o vocábulo "plágio" para designar o furto literário de suas obras por Fidêncio. ${ }^{2}$ Marie-Claude Dock diz que, segundo certos eruditos, o delito de plágio era cometido por meios fraudulentos e dolosos, bem como que o significado do plágio literário é uma metáfora criada por Marcial no sentido de que seus versos, projeções de sua personalidade, são como se fossem os seus filhos. ${ }^{3}$

Há outros registros de plágio literário na Antiguidade. O arquiteto romano Vitrúvio relata sobre um concurso literário e artístico fundado por um dos Ptolomeus em honra das Musas e de Apolo em Alexandria. Aristófanes, um dos julgadores do concurso, preferiu um dos concorrentes aos outros de predileção da opinião pública. Aristófanes, para fundamentar sua decisão, buscou na biblioteca de Alexandria os volumes de que supostamente os outros concorrentes teriam extraído os seus versos, o que foi confirmado e motivou a condenação de ignomínia dos concorrentes plagiadores pelo rei. ${ }^{4}$

Outro episódio é a usurpação do hemistíquio de Virgílio por Batilo, o que levou o

\footnotetext{
${ }^{1}$ RENOUARD, Augustin-Charles. Traité des droits d'auteur, dans la literature: les sciences et les beauxarts. Paris: Jules Renouard \& Cie, 1838, t. 1, p. 16. Disponível em: <http://gallica.bnf.fr/ark:/12148/bpt6k573 9469p>. Sobre a Lex Fabia de Plagiariis, v. D.48.15.

${ }^{2}$ DOCK, Marie-Claude. Contribution historique à l'étude des Droits d'Auteur. Paris: LGDJ, 1962, p. 37.

Trata-se da epigrama I, 53.

${ }^{3}$ Ibidem, p. 39.

${ }^{4}$ RENOUARD, Augustin-Charles. Op. cit., p. 16.
} 
poeta vitimado a escrever: "Sic vos, non vobis". 5 Charles-Augustin Renouard afirma que "existe plagiadores desde que há autores". 6

Os concursos literários, introduzidos em Roma por Augusto, eram os eventos nos quais os poetas podiam ter o reconhecimento público de seus talentos. Os autores de obras literárias eram remunerados pelos seus méritos mediante honorários. ${ }^{7}$ A palavra "mecenas" - patrocinador das letras e das artes - deriva do nome próprio de Mecenas, que ficou imortalizado por Horácio. ${ }^{8}$

Cabe ressaltar que o material para a fixação da obra intelectual literária era escasso. O papiro, oriundo do Egito, não era facilmente encontrado. Paulo Evaristo Arns diz que S. Jerônimo, no século IV, teve muitas dificuldades para encontrar o papiro, dispensando soma considerável em Alexandria na compra do material. ${ }^{9}$ Aos poucos o papiro foi sendo substituído pelo pergaminho, material mais resistente e duradouro. ${ }^{10}$

O autor de obra literária entregava o manuscrito original ao livreiro, perdendo a titularidade da obra, sem remuneração. ${ }^{11}$ A scriptura, conforme o disposto nas Institutas de Gaio (Gai. 2.77) e nas Institutas de Justiniano (Inst. 2.1.33), se agregava ao suporte material (a tábua de madeira ou de cera; o papiro ou o pergaminho) de modo que o seu proprietário adquiria a titularidade sobre o escrito. ${ }^{12}$

A fabricação das cópias do manuscrito original era feita por meio de copistas, geralmente escravos gregos de alto custo pecuniário. ${ }^{13}$ Tratava-se de processo complexo

\footnotetext{
${ }^{5}$ RENOUARD, Augustin-Charles. Op. cit., p. 15.

${ }^{6}$ Ibidem, p. 15.

${ }^{7}$ DOCK, Marie-Claude. Op. cit., p. 42-43.

${ }^{8}$ POUILLET, Eugène. Traité théorique et pratique de la propriété littéraire et artistique et du droit du répresentation. Paris: Imprimerie et Librerie Générale de Jurisprudence Marchal, Billard et Compagnie, 1879. Disponível em: 〈http://gallica.bnf.fr/ark:/12148/bpt6k5545122s〉. Acesso em: 06 jul. 2011.

${ }^{9}$ ARNS, Paulo Evaristo. A técnica do livro segundo São Jerônimo. Tradução Cleone Augusto Rodrigues. 2 ed. São Paulo: Cosac Naify, 2007.

${ }^{10}$ Ibidem, p.26.

${ }^{11}$ DE MATTIA, Fábio Maria. Do privilégio do editor ao aparecimento da propriedade literária e artística em fins do século XVIII. In: Revista de Informação Legislativa. Brasília: Senado Federal, v. 16, n. 63, p. 161182, jul./set. 1979. Disponível em: <http://www2.senado.gov.br/bdsf/item/id/181148>. Acesso em: 06 jul. 2011, p. 162.

${ }^{12}$ CHINELLATO, Silmara Juny de Abreu. Direito de autor e direitos da personalidade: reflexões à luz do Código Civil. 2009. 272 p. Tese (Concurso para Professor Titular do Departamento de Direito Civil) Faculdade de Direito, Universidade de São Paulo, 2008, p. 27-34.

${ }^{13}$ DOCK, Marie-Claude. Op. cit., p. 13.
} 
em que, em síntese, uma pessoa ditava aos copistas, que muitas vezes cometiam erros nas transcrições. $^{14}$

Os editores eram denominados de bibliopola e librarius. Diz Marie-Claude Dock que os bibliopola exerciam sua atividade próximos aos fóruns, em lojas com cartazes contendo as obras para venda. As lojas dos bibliopola eram, ainda de acordo com MarieClaude Dock, um verdadeiro salão literário. ${ }^{15}$

Por seu turno, o controle sobre os exemplares não deveria ser fácil, pois quem adquirisse um exemplar também poderia copiá-lo sem nenhuma restrição ou punição. Isto ensejaria o delito que bem mais tarde foi denominado de "contrafação" — cópia não autorizada, tanto pelo autor como pelo editor, de maneira a ocorrer danos materiais e morais. Destaca-se que não havia em Roma uma legislação específica sobre o Direito de Autor, não havendo nenhuma menção explícita no Corpus Iuris Civilis. ${ }^{16}$

Não havia também uma norma jurídica que dispusesse sobre a usurpação de paternidade. A actio injuriarum era o meio de proteção de danos contra a honra, mas não de proteção de plágio literário. Marie-Claude Dock, após analisar as opiniões de alguns estudiosos sobre a aplicação da Lex Fabia de Plagiariis e da actio injuriarum, conclui que os autores tinham consciência de seus direitos, mas sem uma norma jurídica específica para punir as violações. ${ }^{17}$

Malgrado não houvesse em Roma uma norma jurídica específica para proteger e reprimir as violações do Direito de Autor, havia um senso comum, mesmo que lastreado na moral, da paternidade das obras. Isto é evidente nos casos referidos acima de usurpação de paternidade, sobretudo do poeta Marcial, considerado o primeiro a empregar o vocábulo "plágio" para o furto literário. Além disso, a autoria, criação intelectual, não era desconhecida ou insignificante para os romanos, uma vez que os poetas, coroados em concursos ou admirados pelo público mais refinado, tinham o reconhecimento público de seus talentos literários. Portanto, não havia propriamente um sistema de Direito de Autor

\footnotetext{
${ }^{14}$ ARNS, D. Paulo Evaristo. Op. cit., cap. 2, p. 43-79.

${ }^{15}$ DOCK, Marie-Claude. Op. cit., p. 13.

${ }^{16}$ DE MATTIA, Fábio Maria. Do privilégio do editor... Op. cit., p. 163.

${ }^{17}$ DOCK, Marie-Claude. Op. cit., p. 40.
} 
como o hodierno, mas existia um respeito pela honorabilidade de quem era criador de obra intelectual.

\subsection{O sistema de privilégios e a imprensa}

Após a queda do Império Romano do Ocidente, surge uma instituição que marcará a transmissão do conhecimento: a universidade. A primeira universidade do Ocidente foi a de Bolonha, fundada em 1088. Surgiram novas instituições centralizadas e voltadas para o fomento intelectual ao longo da Idade Média e dos séculos posteriores.

A Universidade de Paris, segundo Jacques Le Goff, formava no século XIII uma corporação composta de quatro faculdades: Artes, Decreto ou Direito Canônico, Medicina e Teologia. ${ }^{18} \mathrm{O}$ livro, ainda segundo este autor, era o instrumento indispensável para o acompanhamento do curso pelos alunos, bem como o meio de registrar as lições dos docentes. ${ }^{19}$ Vê-se que o livro se tornou um instrumento cada vez mais necessário não somente para a transmissão de obras literárias, como narrativas e poemas, mas, sobretudo, de um conhecimento sistematizado. Nesse período, o Estatuto da Universidade de Pádua dizia: "sem exemplares (livros) não haveria a Universidade". ${ }^{20}$

Paulo Evaristo Arns, na sua tese já mencionada, aborda pormenorizadamente o processo de fabricação do livro na época de S. Jerônimo. Cada livro no século XIII, porém, como na Roma Antiga, ainda era transcrito manualmente por um copista. Contudo, como salienta Le Goff, mesmo sendo copiado, o modo de produção do livro tornou-se mais rápido para atender a demanda cada vez mais crescente dos estudantes. As dimensões do livro diminuíram de maneira a melhorar o seu transporte e a sua consulta, bem como as letras minúsculas góticas permitiam aos copistas a escrita mais rápida: era o nascimento dos manuais. Ressalta-se que muitos dos copistas eram universitários mais desfavorecidos. $^{21}$

Por sua vez, ao redor das universidades crescia o comércio de livros. Os livreiros eram chamados naquele período de librarii ou de stationarii, esta denominação porque

\footnotetext{
${ }^{18}$ LE GOFF, Jacques. Les intellectuels au moyen âge. Paris: Seuil, 2000, p. 82.

${ }^{19}$ Ibidem, p. 95.

${ }^{20}$ Ibidem, p. 96.

${ }^{21}$ Ibidem, p. 96-97.
} 
expunham os seus livros à venda. Eles recebiam da universidade o privilégio para publicação de livros e estavam sob a jurisdição universitária. A universidade fiscalizava a atividade dos livreiros, determinando o preço, o conteúdo e as correções dos textos antes de serem publicados. $^{22}$

O privilégio para publicação de livros, na França, era da Universidade de Paris. Um edito de Carlos VI, transcrito por Augustin-Charles Renouard, demonstra como era o estado da publicação de livros no século $\mathrm{XV}$, enfatizando que, além do privilégio real concedido à Universidade de Paris, havia também outra atribuição da universidade: a censura prévia. ${ }^{23}$ Havia duas funções no privilégio, segundo Fábio Maria De Mattia: a censura prévia, não permitindo que a obra contivesse subversões, e a outorga de exclusividade ao livreiro na publicação. ${ }^{24}$

Um dos privilégios mais antigos que se tem notícia foi o privilégio concedido pelo Senado da Sereníssima República de Veneza ao livreiro Giovanni di Spira em 1469. ${ }^{25}$

O advento da imprensa permitiu o florescimento da edição de livros. Essa nova forma de fabricar mais exemplares com menor quantidade de erros trouxe também o aumento de livros contrafeitos. Charles Augustin Renouard diz que o trabalho do impressor era tão complexo quanto o dos copistas, apesar de a imprensa possibilitar maior multiplicação de exemplares. Todavia, segundo o mesmo autor, concomitantemente apareciam os imitadores, que publicavam as obras sem os cuidados e os riscos do empreendimento do primeiro editor. ${ }^{26}$

A norma jurídica denominada "l'arrêt", de 11 de setembro de 1665, no Reino da França, possibilitava ao livreiro detentor do privilégio fazer a apreensão de todos os exemplares contrafeitos e noticiar ao Conselho Real o fato delituoso. ${ }^{27}$

\footnotetext{
${ }^{22}$ RENOUARD, Augustin-Charles. Op. cit., p 18-19.

${ }^{23}$ Ibidem, p 18-19.

${ }^{24}$ DE MATTIA, Fábio. Do privilégio do editor... Op. cit., p. 164.

${ }^{25}$ LUCAS, André; LUCAS, Henri-Jacques. Traité de la propriété littéraire \& artistique. 3 ed., Paris: LITEC, 2006, p. 3-4.

${ }^{26}$ RENOUARD, Augustin-Charles. Op. cit., p 106.

${ }^{27}$ GASTAMBIDE, Adrien-Joseph. Traité théorique et pratique des contrefaçons en tous genres. Paris: Legrand et Descauriet, 1837. Disponível em: 〈http://gallica.bnf.fr/ark:/12148/bpt6k5727743k〉. Acesso em: 06 jul. 2011.
} 
Quanto aos prazos de exclusividade dos privilégios, Charles Augustin Renouard, apoiado em alguns privilégios concedidos em épocas diferentes, afirma que não havia uniformidade. A duração dos privilégios variava muito. O privilégio era sempre concedido ao livreiro. ${ }^{28}$

Mesmo durante o período de concessão de privilégios, Marie-Claude Dock informa certos privilégios reais outorgados a outros titulares além dos editores. Dentre esses privilégios, destacamos o privilégio concedido às netas do fabulista La Fontaine "por direito de herança". ${ }^{29}$

Cremos que o privilégio, como bem observa Henri-Jacques Lucas, tinha a função mais de proteção industrial, garantindo um modo compensatório para quem tivesse grande dispêndio na confecção de livros. Ademais, ainda conforme esse autor, o privilégio tinha caráter precário e arbitrário. ${ }^{30}$

\subsection{O Estatuto da Rainha Ana}

A situação do autor na Inglaterra, antes do Estatuto da Rainha Ana, não era muito diversa daquela que acabamos de expor.

O privilégio para publicação dos livros era da corporação Stationer's Company, corporação criada pelo Decreto Real de 1556 para agrupar os principais livreiros de Londres, bem como para controlar as publicações de modo a não haver escritos subversivos com apoio da Camara Stellata. Como nos informa Françon, essa câmara tinha jurisdição em matéria criminal. ${ }^{31}$

A Camara Stellata foi extinta, continua Françon, em 1640, não se alterando a situação dos autores. O Parlamento, por meio de muitos Licensing Acts, submetia a publicação das obras à autorização prévia, devendo haver o registro do título da obra em nome de um dos membros da corporação. Ainda conforme Françon, no momento da cessão

\footnotetext{
${ }^{28}$ RENOUARD, Augustin-Charles. Op. cit., p 109.

${ }^{29}$ DOCK, Marie-Claude. Op. cit., p. 120.

${ }^{30}$ LUCAS, André; LUCAS, Henri-Jacques. Op. cit., p. 04.

${ }^{31}$ FRANÇON, André. La propriété littéraire et artistique en grande-bretagne et aux États-Unis. Paris: Arthur Rousseau, 1955, p. 08.
} 
dos efeitos da Licensing Act, os livreiros da Stationer's Company tinham que tolerar a concorrência. Contudo, no seio da corporação, havia um estatuto interno que sancionava com penas severas o membro que não o observasse. ${ }^{32}$

A Stationer's Company proporcionou o desenvolvimento do copyright, segundo De Mattia, ao controlar o comércio de livros e proteger de contrafações as obras publicadas. O titular do direito de reprodução, continua Fábio Maria De Mattia, era o livreiro membro da corporação. $^{33}$

No entanto, a situação mudaria com a publicação do Estatuto da Rainha Ana, de 1710. A proposta do Estatuto foi apresentada ao Parlamento por Edward Worley, em 11 de janeiro de 1710, sendo o início da vigência do Estatuto a data de 10 de abril de $1710 .{ }^{34}$

O Estatuto outorgou o direito de reprodução (copyright) aos autores sobre os seus escritos, que antes dependiam completamente dos livreiros da Stationer's Company. Qualquer livreiro, segundo o Estatuto, poderia publicar independentemente de ser membro daquela corporação. Mas ainda havia certas formalidades no exercício do copyright: o autor, para ser amparado pelo estatuto, deveria registrar o título da obra na Stationer's Company e fazer o depósito de nove exemplares destinados às bibliotecas públicas e às universidades. $^{35}$

A duração do direito de reprodução, de acordo com o Estatuto da Rainha, era de 21 anos para os livros já publicados e de 14 anos para os livros publicados durante a vigência do Estatuto. ${ }^{36}$

Muito embora o Estatuto da Rainha Ana dispusesse apenas sobre o direito de reprodução, que a partir de 1710 passou dos livreiros da Stationer's Company para os autores de escritos, é o marco no enfoque do direito sobre as criações intelectuais aos autores.

\footnotetext{
${ }^{32}$ FRANÇON, André. Op. cit., p. 08.

${ }^{33}$ DE MATTIA, Fábio Maria. Do privilégio do editor... Op. cit., p. 174-175.

${ }^{34}$ Ibidem, p. 176-178.

${ }^{35}$ LIPSZYC, Delia. Derecho de autor y derechos conexos. Reimpresión inalterada de la edición de 1993. Buenos Aires: UNESCO; CERLALC; ZAVALIA, 2001, p. 31-32.

${ }^{36}$ FRANÇON, André. Op. cit., p. 09.
} 
Assim como ocorria na França, na Inglaterra a disciplina jurídica da Stationer's Company visava ao monopólio econômico de um grupo de livreiros e à censura prévia, isto é, havia um interesse maior de censura que de controle econômico.

\subsection{A Lei "Le Chapelier"}

Com o advento da Revolução Francesa, considerando-se como marco a Tomada da Bastilha em julho de 1789, o Antigo Regime sofreu uma mudança completa. Muitos dos antigos institutos ou instituições foram excluídos do novo regime ou sofreram mudanças radicais. Cabe destacar o instituto da propriedade, sobretudo a propriedade imobiliária, sendo mais um símbolo de poder político que econômico.

Na seara jusautoralista inicia-se uma nova determinante.

Le Chapelier, em nome do Comitê Constituinte, apresentou um projeto de lei em 13 de janeiro de 1791. Charles Augustin Renouard nos relata que as reclamações sobre a abolição dos privilégios vinham dos autores de artes dramáticas contra o privilégio dos autores da Comédie Française. Sucintamente, aqueles protestam pela duração do seu direito de exclusivo durante toda a duração de suas vidas, tal como era concedido para estes, e durante cinco anos para os seus cessionários e herdeiros. ${ }^{37}$

Transcrevemos abaixo parte do relatório de Le Chapelier, constante na obra de Charles Augustin Renouard: “A mais sagrada, a mais legítima, a mais inatacável, e se posso falar também, a mais pessoal das propriedades, é a obra fruto do pensamento de um escritor; contudo, é uma propriedade de um gênero todo diferente das outras propriedades." $" 38$

Continua Le Chapelier expondo os motivos do projeto de lei:

Quando um autor liberou sua obra ao público, quando esta obra está nas mãos de todo mundo, quando todos os homens instruídos a conheçam, quando se apoderam das belezas que a contêm, quando retém na memória

\footnotetext{
${ }^{37}$ RENOUARD, Augustin-Charles. Op. cit., p 308.

${ }^{38}$ Ibidem, p 309. Tradução nossa. No original: “La plus sacré, dit-il, la plus légitime, la plus inattaquable, et si je puis parler ainsi, la plus personelle des propriétés, est l'ouvrage fruit de la pensée d'un écrivain; cependant c'est une propriété d'un genre tout différent des autres propriétés.".
} 
os traços mais felizes, parece que, a partir desse momento, o escritor associou o público à sua propriedade, ou antes a transmitiu inteira. No entanto, como é extremamente justo que os homens que cultuam o domínio do pensamento percebam alguns frutos de seu trabalho, é preciso que, durante toda sua vida e alguns anos após a morte, ninguém possa, sem o seu consentimento, dispor do produto de seu gênio. Por outro lado, depois do prazo fixado, a propriedade do público começa, e todo mundo pode imprimir, publicar as obras que contribuíram para esclarecer o espírito humano. Eis o que acontece na Inglaterra para os autores e o público, por atos que denominamos de tutelares; o que se fazia outrora na França pelos privilégios que o rei concedia, e que será daqui em diante fixado por uma lei, meio mais sábio e o único que convém empregar. ${ }^{39}$

Le Chapelier, segundo Henri-Jacques Lucas, entendia que o domínio público seria a regra geral e o direito de autor a exceção. ${ }^{40}$ A propriedade dos autores, ainda de acordo com Henri-Jacques Lucas, teria o seu fundamento mais em opiniões filosóficas que jurídicas, enfatizando-se o rompimento com o antigo sistema de privilégios. ${ }^{41}$

Embora Le Chapelier no seu discurso se refira aos escritores, a Lei de 13 de janeiro de 1791 regulamentava apenas o direito de representação dos autores de obras dramáticas. ${ }^{42}$ Alguns meses mais tarde, a Lei de 19-24 de julho de 1791 veio a disciplinar o direito dos escritores de todos os gêneros, compositores de música, pintores e desenhistas. $^{43}$

$\mathrm{O}$ art. $1^{\mathrm{o}}$ da Lei de 19-24 de julho de 1791 garantia o direito de exclusivo aos autores sobre suas obras por toda a vida e a cessão desse direito. Quanto ao prazo post mortem, a lei dispunha no art. $2^{\circ}$ a duração de 10 anos aos herdeiros e cessionários. A pena para os contrafatores era a multa no valor de três mil exemplares da edição original

\footnotetext{
${ }^{39}$ RENOUARD, Augustin-Charles. Op. cit., p 309, tradução nossa. No original: "Quand un auteur a livré son ouvrage au public, quand cet ouvrage est dans les mains de tout le monde, que tous les hommes instruits le connaissent, qu'ils sont emparés des beautés qu'il contient, qu'ils en ont confié à leur mémoire les traits les plus heureux, il semble que, dès ce moment, l'écrivain a associé le public à sa propriété, ou plutôt la lui a transmise tout entière. Cependant, comme il est extrêmement juste que les hommes qui cultivent le domaine de la pensée tirent quelques fruits de leur travail, il faut que, pendant toute leur vie et quelques années après leur mort, personne ne puisse, sans leur consentement, disposer du produit de leur genie. Mais aussi, après le délai fixé, la propriété du public commence, et tout le monde doit pouvoir imprimer, publier, les ouvrages qui ont contribute à éclairer l'esprit humain. Voilà ce qui s'opère en Angleterre pour les auteurs et le public, par des actes que l'on nomme tutélaires; ce qui se faisait autrefois en France par des privilèges que le roi accordait, et ce qui sera dorénavant fixé par une loi, moyen beaucoup plus sage et le seul qu'il convienne d'employer."

${ }^{40}$ LUCAS, André; LUCAS, Henri-Jacques. Op. cit., p. 10.

${ }^{41}$ Ibidem, p. 11. Na conclusão de sua tese retrocitada, a Professora Silmara Juny de Abreu Chinellato afirma que o Direito de Autor não é um direito de propriedade. (Cf. CHINELLATO, Silmara Juny de Abreu. Op. cit., p. 254-257).

${ }^{42}$ RENOUARD, Augustin-Charles. Op. cit., p 315.

${ }^{43}$ Ibidem, p 325 .
} 
destinada ao autor (art. $4^{\circ}$ ). Em seguida, a mesma lei obrigava ao depósito de dois exemplares na Biblioteca Nacional, condição para provar em juízo em caso de contrafação $\left(\right.$ art. $\left.6^{\circ}\right) .{ }^{44}$ Em nenhum momento a lei menciona os plágios literário, musical ou de obras plásticas.

\subsection{A Convenção de Berna}

No âmbito da Société des Gens de Lettres, sociedade presidida pelo escritor Victor Hugo, em 1878 foi realizado o Congresso Literário Internacional, que criou a Associação Literária e Artística Internacional - ALAI. Nesse congresso estabeleceram-se os princípios do tratamento nacional das obras estrangeiras, da proteção automática e da independência da proteção. ${ }^{45}$

Vale ressaltar que as obras literárias não ficavam restritas ao território do país de seus autores, uma tendência já observada em outras épocas. Como vimos acima, o advento da imprensa propiciou o aumento de exemplares de uma obra, mas também as cópias não autorizadas e de pior qualidade.

Relata Lipszyc que no Congresso da ALAI de 1882, realizado em Roma, os participantes propuseram a constituição de uma sociedade semelhante à já existente União Postal Universal - UPU, sob a denominação de "União de Propriedade Literária". 46 Conforme o art. $1^{\circ}$ da Convenção de Berna, constituiu-se uma União entre os países.

O texto da Convenção de Berna, de 6 de setembro de 1886, foi concluído após três conferências diplomáticas ocorridas em Berna no mês de setembro dos três anos anteriores. $^{47}$

No que se refere às medidas preventivas de reproduções ilícitas, o art. 12 da Convenção estabelece que se aplica a lex fori ${ }^{48}$ Não há menção a obras plagiadas.

\footnotetext{
${ }^{44}$ RENOUARD, Augustin-Charles. Op. cit., p.327.

${ }^{45}$ LIPSZYC, Delia. Op. cit., p. 618.

${ }^{46}$ Ibidem, p. 619.

${ }^{47}$ Ibidem, p. 618-620.

${ }^{48}$ Ibidem, p. 626 . No texto atual da Convenção é o art. 16.
} 
Gustave Huard diz que o aditamento de Paris da Convenção de Berna, de 15 de abril de 1896, corrigiu um erro constante no art. $3^{\circ}$, que dispunha que os editores eram protegidos nos países da União quando o autor não pertencesse a um país unionista. ${ }^{49}$

A Convenção de Berna, ainda vigente com alterações, no entender de José de Oliveira Ascenção é o "instrumento-padrão" no âmbito internacional, o que pode ser verificado nas referências explícitas nos diplomas legais internacionais sobre a matéria. ${ }^{50}$

\subsection{O Direito de Autor antes do Código Civil de 1916}

No Brasil, durante o período colonial, era proibido imprimir qualquer obra literária, conforme a Ordem Régia de D. João V, de 10 de maio de 1747, sob pena de confisco do material empregado para impressão. Todavia, de acordo com o Visconde de Porto Seguro, houve um impressor no Rio de Janeiro, Antônio Isidoro da Fonseca, que publicou a obra intitulada "Exame de bombeiros", de autoria de José Fernandez Pinto Alpoim, em 1748. ${ }^{51}$

Somente com a vinda da família real ao Brasil findou a proibição de haver qualquer imprensa. Pelo Decreto do Príncipe Regente D. João, de 13 de maio de 1808, é criada a Imprensa Régia para publicar os atos oficiais. ${ }^{52}$ D. João, por meio do Decreto de 27 de junho de 1810, ordena que a Real Biblioteca fosse instalada nas Casas dos Hospitais da Ordem Terceira do Carmo, o germe da atual Biblioteca Nacional, criada pelo Decreto de 29 de outubro de $1810^{53}$

A Constituição do Império não tratou do Direito de Autor. O inciso XXVI do art. 179, artigo que regulamenta os direitos civis e políticos dos cidadãos brasileiros, disciplinou apenas o direito do inventor, criador de trabalho intelectual de natureza diversa da do autor. ${ }^{54}$

\footnotetext{
${ }^{49}$ HUARD, Gustave. Traité de la propriété intellectuelle. Paris: Marchal e Billard, 1903, t. 1, p. 266-267. Disponível em: 〈http://gallica.bnf.fr/ark:/12148/bpt6k5459737k>. Acesso em: 06 jul. 2011.

${ }^{50}$ ASCENSÃO, José de Oliveira. Direito Autoral. 2. ed., Rio de Janeiro: Renovar, 2007, p. 639.

${ }^{51}$ VARNHAGEM, Francisco Adolfo de (Visconde de Porto Seguro). História geral do Brasil antes de sua separação e independência. Belo Horizonte: Itatiaia, 1981, p. 92.

52 BRASIL. Decreto do Príncipe Regente D. João, de 13 de maio de 1808. Disponível em: <http://www.planalto.gov.br/ccivil_03/revista/Rev_27/dim1305003.htm>. Acesso em: 06 jul. 2011.

${ }^{53}$ BRASIL. Decreto de 29 de outubro de 1810. Índice de Leis Históricas. Disponível em: <http:// www.planalto.gov.br/CCIVIL_03/revista/Rev_69/Decreto.htm>. Acesso em: 06 jul. 2011.

${ }^{54}$ BRASIL. Constituição Política do Império do Brasil. Disponível em: <http://www.planalto.gov.br/ ccivil_03/constituicao/constituicao24.htm>. Acesso em: 06 jul. 2011.
} 
A primeira lei a disciplinar de maneira explícita o Direito de Autor no Brasil é a Lei de 11 de agosto de 1827, criadora dos cursos jurídicos. $\mathrm{O}$ art. $7^{\circ}$ trata do "privilégio de exclusivo" dos lentes por seus compêndios pelo período de dez anos. ${ }^{55}$

Por seu turno, o Código Criminal do Império — Lei de 16 de dezembro de 1830 -, amplia a proteção autoral incluindo os autores, não somente os lentes das Academias de Direito, tradutores e herdeiros destes. No Título III, Capítulo I - Do Furto, dispõe no art. 261 sobre as violações do direito de autor, impondo pena de apreensão das cópias não autorizadas ou, na falta, multa igual ou superior ao triplo do valor dos exemplares. Os autores gozam do direito durante toda a vida, segundo o mesmo artigo, e também os seus herdeiros por dez anos após a morte. Não há nesse diploma legal nenhuma disposição sobre plágio, referindo-se apenas sobre o suporte material — "escriptos, ou estampas" bem como a contrafação. ${ }^{56}$

No Império não houve uma lei específica a regulamentar o Direito de Autor. Ambas as leis citadas acima disciplinam o prazo de duração do direito de exclusivo sem definir quem é o autor e sem expor detalhadamente os seus direitos.

A Constituição Federal de 1891, a primeira da nova ordem política, consagrou o Direito de Autor na parte dedicada aos direitos individuais, no $§ 26$ do art. 72. De modo diverso da Carta anterior, não foi empregado o vocábulo "privilégio", mas "direito de exclusivo" aos autores e aos seus herdeiros. O prazo de proteção seria disciplinado em lei especial. $^{57}$

De acordo com José de Oliveira Ascenção, a Constituição Federal de 1891 foi a primeira Carta a consagrar o Direito de Autor no Brasil, o que, a partir de então, seria seguido nas Cartas posteriores, excetuando-se somente a Constituição Federal de $1937 .{ }^{58}$

Por seu turno, o Código Penal de 1890 — Decreto n. 847, de 11 de outubro de 1890

\footnotetext{
${ }^{55}$ COSTA NETO, José Carlos. Direito Autoral no Brasil. 2. ed., São Paulo: FTD, 2008, p. 62.

56 BRASIL. Código Criminal do Império. Disponível em <http://www.planalto.gov.br/ccivil_03/ Leis/LIM/LIM-16-12-1830.htm>. Acesso em: 06 jul. 2011.

57 BRASIL. Constituição da República dos Estados Unidos do Brasil 1891. Disponível em: <http://www.planalto.gov.br/ccivil_03/constituicao/Constitui\%C3\%A7ao91.htm>. Acesso em: 06 jul. 2011.

${ }^{58}$ ASCENSÃO, José de Oliveira. Op. cit., p. 12.
} 
—, dedicou toda a Secção I do Capítulo V do Título XII aos Crimes contra a Propriedade, Literária, Artística, Industrial e Comercial. ${ }^{59}$

O Código Penal de 1890 nasceu numa nova ordem política: a República. Todavia, sofreu duras críticas tanto à redação como à disposição das matérias. O autor do Anteprojeto, João Batista Pereira, já tinha sido incumbido de elaborar um Anteprojeto de Código Penal pouco antes da Proclamação da República. Com o nascimento desta, Batista Pereira novamente foi encarregado do mesmo mister pelo Ministro da Justiça do Governo Provisório, Campo Salles. Em pouco mais de três meses, Batista enviou o Anteprojeto de Código Penal, que foi sancionado pelo Decreto n. 847, de 11 de outubro de 1890. A principal crítica é referente ao sistema e à redação, que são inferiores ao Código Criminal do Império. ${ }^{60}$

Destacamos os artigos 345, 346, 347 e 350, do Código Penal de 1890. O art. 345 trata da reprodução não autorizada, bem como do prazo de 10 anos post mortem de duração do direito de exclusivo de autor. Em seguida, o art. 346 dispõe sobre a transcrição completa de obras orais sem consentimento do autor, cuja pena é de apreensão e perda dos exemplares e multa destinada ao autor. Por sua vez, o art. 347 disciplina a obra derivada, em especial a tradução, sem autorização do autor, mas não punindo a citação para fins didáticos e críticos.

Frisa-se que o sentido de contrafação e de imitação no art. 350 do Código Penal de 1890, não estão definidos no caput do artigo, bem como não há uma distinção entre ambos atos ilícitos:

\footnotetext{
Art. 350. Reproduzir qualquer producção artistica, sem consentimento do dono, por imitação ou contrafacção:

Penas - as do artigo antecedente.

Paragrapho unico. Para este effeito reputar-se-ha contrafacção:

$1^{\circ}$ A reproducção em pintura, quando um artista, sem consentimento do autor, ou daquelle a quem transferiu a propriedade artistica, copiar em um quadro grupos, figuras, cabeças ou detalhes de paisagens, ou os fizer entrar no proprio quadro, conservando as mesmas proporções e os mesmos effeitos de luz que na obra original;
}

59 BRASIL. Código Penal: Decreto n. 847, de 11 de outubro de 1890. Disponível em: <http://www6.senado.gov.br/legislacao/ListaPublicacoes.action?id=66049>. Acesso em: 05 set. 2011.

${ }^{60}$ PIERANGELI, José Henrique. Códigos Penais do Brasil: evolução histórica. 2. ed. São Paulo: Revista dos Tribunais, 2001, p. 74 e 75. 
$2^{\circ} \mathrm{A}$ reproducção em esculptura, quando o imitador tomar em uma obra original, grupos, figuras, cabeças, ornamentos e os fizer entrar na obra executada por elle;

$3^{\circ}$ A reproducção em musica, quando se arranjar uma composição musical para um instrumento só, tendo sido feita para orchestra, ou para um instrumento differente daquelle para o qual foi composta. ${ }^{61}$

Constatamos que o parágrafo único do art. 350 limita demasiadamente em seus números as situações de contrafação para determinadas obras, não se valendo de uma definição mais genérica e abrangente. Da leitura dos números do parágrafo único, inferimos que o legislador seguiu uma via casuística, o que pensamos não ser a melhor forma de criar um tipo penal. ${ }^{62}$ A seguir, observaremos que a Lei n. 496, de $1^{\circ}$ de agosto de 1898, a nosso ver, melhorou o sentido legal de contrafação.

Antes da Lei n. 496, de $1^{\circ}$ de agosto de 1898, foram apresentados à Assembleia Geral dois Projetos de Lei: o projeto de Gavião Peixoto e Aprígio Guimarães, em 1856, e outro, em 1875, corroborado pelo escritor José de Alencar. ${ }^{63}$

A Lei n. 496 , de $1^{\circ}$ de agosto de 1898 , foi a primeira lei brasileira a disciplinar a matéria de Direito de Autor em detalhes. Os diplomas jurídicos anteriores garantiram ao autor o direito de exclusivo durante um prazo determinado, protegendo-o com sanções penais contra as violações. No entanto, a Lei n. 496/1898 vai além ao definir os direitos de autor $\left(\operatorname{art.} 1^{\circ}\right)$ e as obras literária, científica e artística (art. $2^{\circ}$ ), entre outras disposições.

$\mathrm{O}$ art. $1^{\circ}$ da Lei n. 496 define os direitos de autor, que "consistem na faculdade, que só ele tem, de reproduzir ou autorizar a reprodução do seu trabalho pela publicação, tradução, representação, execução ou de qualquer outro modo."64 Eugène Pouillet, ao analisar a natureza do Direito de Autor, diz que o Direito de Autor é a faculdade que a lei atribui ao autor de explorar sua obra, dentro de um prazo determinado, excluindo os outros,

${ }^{61}$ BRASIL. Código Penal: Decreto n. 847, de 11 de outubro de 1890. Op. cit.

${ }^{62}$ Nesse sentido, Francisco de Assis Toledo nos ensina que: "Em direito penal classificam-se em tipos algumas formas de comportamento humano. De um modo geral, o tipo é, pois, um conceito abstrato elaborado com o material obtido daquele "algo de comum" que retiramos de uma variedade de entes particulares." (TOLEDO, Francisco de Assis. Princípios básicos de Direito Penal. 5. ed. São Paulo: Saraiva, 1994, p. 126, itálico no original.)

${ }^{63}$ CHINELLATO, Silmara Juny de Abreu. Op.cit., p. 56.

64 BRASIL. Lei n. 496, de $1^{\mathbf{0}}$ de agosto de 1898. Disponível em: <http://www6.senado.gov.br/ legislacao/ListaPublicacoes.action?id=60815\&tipoDocumento=LEI\&tipoTexto=PUB $>$. Acesso em: 06 jul. 2011. 
em seu benefício. ${ }^{65}$ Clóvis Bevilacqua afirma que o relator do projeto da Lei n. 496/1898, Medeiros de Alburquerque, seguiu o entendimento de que o Direito de Autor é um monopólio de exploração. ${ }^{66}$

O prazo de duração da faculdade exclusiva é de cinquenta anos a contar de $1^{\circ}$ de janeiro de ano subsequente à publicação $\left(\S 1^{\circ}\right.$, art. $\left.3^{\circ}\right)$, sendo de dez anos o prazo para obras derivadas, a contar, no caso das traduções, a partir do dia $1^{\circ}$ de janeiro do ano em que a tradução for publicada, e, no caso das representações e execuções, da primeira apresentação autorizada pelo autor $\left(\S 2^{\circ}\right.$, art. $\left.3^{\circ}\right)$.

A natureza do Direito de Autor, consoante o art. $4^{\circ}$ da Lei n. 496/1898, é de bem móvel, podendo ser cedida ou transmitido no todo ou em parte. $\mathrm{O} \S 1^{\circ}$ do art. $4^{\circ}$ diz que a cessão entre vivos tem prazo máximo de trinta anos. Os $\S \S 2^{\circ}, 3^{\circ}$ e $4^{\circ}$ do mesmo artigo tratam do contrato de edição.

Em linhas gerais, há disposições sobre o direito moral de autor, como o direito à integridade (art. $5^{\circ}$ ) e a impenhorabilidade dos direitos morais (art. $7^{\circ}$ ). Os direitos conexos de autor, em especial, são disciplinados pela lei, o que não havia sido feito anteriormente, pois não haviam sido sequer mencionados. Os titulares de direito de autor, no caso de obra em colaboração, são denominados pela lei como coproprietários (art. $\left.9^{\circ}\right)$. Os direitos sobre as obras anônimas e pseudônimas são do editor, até que se conheça o nome civil do autor (art. 11).

$\mathrm{O}$ art. 13 condiciona o registro das obras na Biblioteca Nacional para o gozo dos direitos. Cremos que o registro da obra seja uma formalidade necessária para o exercício dos direitos de autor, uma vez que é uma condição indispensável, consoante a letra desse artigo. O registro deve ser feito no prazo de dois anos após a publicação. Diz o início do caput do artigo em comento: “Art. 13. É formalidade indispensavel para entrar no goso dos direitos de autor o registro da Bibliotheca Nacional [...]". ${ }^{67}$

\footnotetext{
${ }^{65}$ POUILLET, Eugène. Op. cit., p. 15 e 16.

${ }^{66}$ BEVILACQUA, Clóvis. Direito das coisas. Rio de Janeiro: Freitas Bastos, 1941. Edição fac-símile. Rio de Janeiro: Rio, 1976, v. 1, p. 272.

${ }^{67}$ BRASIL. Lei n. 496, de $1^{\circ}$ de agosto de 1898. Op. cit.
} 
As obras plásticas de aplicação industrial têm a mesma proteção de outras obras, de acordo com o art. 18, exceto se perderem o caráter artístico.

Nos artigos 19 usque 21 estão disciplinadas as violações dos direitos de autor. O art. 19, em especial, diz:

Art. 19. Todo o attentado doloso ou fraudulento contra os direitos de autor constitue o crime de contrafacção. Os que scientemente vendem, expoem á venda, teem em seus estabelecimentos para serem vendidos ou introduzem no territorio da Republica com fim commercial objectos contrafeitos, são culpados do mesmo crime. ${ }^{68}$

A contrafação, no texto da Lei n. n. 496/1898, é definida como sinônimo de violação do direito de autor. O artigo acima transcrito não diz, como mais adiante veremos, que contrafação é a reprodução não autorizada.

O caput do art. 22, ao tratar das limitações ao direito de autor, diz: “[...] Não se considera contrafacção". Destaca-se que nos números 1,2 e 5 do rol do art. 22 se enfatiza a indicação do nome do autor, isto é, são lícitos certos usos sem a autorização do autor, mas sempre indicando o seu nome.

\subsection{O Direito de Autor no Código Civil de 1916}

\subsubsection{A disciplina autoral no Código Civil de 1916}

O Direito de Autor e os Direitos Conexos foram regulamentados no Código Civil de 1916 na Parte Especial, no Livro II (Direito das Coisas), Título II (Da Propriedade), Capítulo VI (Da Propriedade Literária, Artística e Científica).

Não foi simples a decisão de Clóvis Bevilacqua de inserir essa matéria no Direito das Coisas. Clóvis Bevilacqua admite, na esteira de Tobias Barreto, que o direito autoral é um direito da personalidade. ${ }^{69}$ Entretanto, o Código Civil de 1916 não disciplinou num artigo específico ou em seção os direitos morais de autor.

\footnotetext{
${ }^{68}$ BRASIL. Lei n. 496, de $1^{\mathbf{0}}$ de agosto de 1898. Op. cit.

${ }^{69}$ BEVILACQUA, Clóvis. Direito das coisas. Op. cit., p. 272.
} 
Por seu turno, Clóvis Bevilacqua ainda acrescenta outras opiniões. Para alguns, o Direito de Autor é uma propriedade comum, apesar de Clóvis Bevilacqua ver a existência de um aspecto econômico e outro pessoal. ${ }^{70} \mathrm{Na}$ sequência da exposição de suas ideias, Clóvis Bevilacqua cita Edmond Picard, que insere o Direito de Autor no gênero dos direitos intelectuais, quarto gênero ao lado dos clássicos direitos pessoais, reais e obrigacionais. ${ }^{71}$ Cita ainda Ihering, para quem o Direito de Autor é uma forma de propriedade intelectual, junto com o Direito Industrial. ${ }^{72}$

Devido à dupla natureza do Direito de Autor, Clóvis Bevilacqua optou pela inserção do Direito Autoral no Livro do Direito das Coisas, como segue:

\begin{abstract}
Abstendo-se de dar á creação jurídica a denominação de propriedade, claramente deixa ver que a distingue do domínio; collocando-a entre os direitos reaes, quiz indicar que, por algum modo, havia similaridade entre essas manifestações juridicas e o direito autoral. É um direito sui generis, que, ou entraria na Parte Geral, ou havia de ser intercalado no livro dedicado ao direito das coisas; que aqui são tomados numa accepção mais extensa do que se dissesse: - coisas corporeas. $^{73}$
\end{abstract}

Conclui Clóvis Bevilacqua que o Direito de Autor tem um lado pessoal, denominado de direito moral, e outro econômico ou patrimonial, denominado de propriedade imaterial. $^{74}$

Como dissemos acima, Le Chapelier dizia que a propriedade do autor é diversa das outras propriedades. Eugène Pouillet entende que a discussão sobre a natureza de propriedade do Direito de Autor é teórica, sendo apenas um problema de vocabulário, pois a lei determina, define, limita os efeitos e a duração dos direitos do autor. ${ }^{75}$

O Código Civil de 1916, em linhas gerais, melhorou a regulamentação dos direitos autorais. Além de tratar do direito de autor e dos direitos conexos no Livro do Direito das

\footnotetext{
${ }^{70}$ BEVILACQUA, Clóvis. Direito das coisas. Op. cit., p. 275.

${ }^{71}$ Ibidem, p. 273.

${ }^{72}$ Ibidem, p. 273.

${ }^{73}$ Ibidem, p. 273, itálicos no original.

${ }^{74}$ Ibidem, p. 274.

${ }^{75}$ POUILLET, Eugène. Op. cit., p.17.
} 
Coisas, disciplinou o contrato de edição e representação dramática no Livro do Direito das Obrigações (Capítulos $9^{\circ}$ e $\left.10^{\circ}\right) .^{76}$

Salienta-se, dentre as disposições do Código Civil de 1916, mais precisas que as da Lei n. 996/1891, a desapropriação por utilidade pública (art. 660), que permite à União e aos Estados efetuar o licenciamento compulsório de obra já editada mediante indenização ao autor. Neste ponto há um conflito entre o direito do autor e o interesse público da cultura. A princípio, somente cabe ao autor ou, em certos casos, ao editor, quando houver disposição contratual expressa, a reedição de uma obra. Não podemos perder de vista que ninguém é obrigado a reeditar uma obra. Um autor pode se arrepender ao longo da vida de ideias ou opiniões manifestadas em um determinado momento.

As violações do direito de autor estão expostas nos arts. 669 usque 672. Não foram denominadas de contrafação, como o fez a Lei n. 496/1898. Em geral, a pena imposta ao ofensor é a apreensão dos exemplares e a indenização ao autor. A responsabilidade de quem expuser à venda ou a leitura pública remunerada sem consentimento do autor é solidária com a do editor (art. 670). O autor ou detentor de direitos tem o direito de ser indenizado, mesmo no caso de não haver nenhum exemplar com o ofensor (art. 673).

Cabe especial atenção ao disposto no caput do art. 669 que diz: “[...] Quem publicar obra inedita, ou reproduzir obra em via de publicação ou já publicada, pertencente a outrem, sem outorga ou acquiescencia deste, [...]". ${ }^{77} \mathrm{O}$ plágio literário, como analisaremos mais adiante, geralmente pode ocorrer nesses momentos, sendo provocado por alguém, v.g., que tenha acesso aos esboços e escritos do autor ainda não publicados; ou pelo editor ou alguém próximo deste durante a análise dos originais para eventual publicação ou na fase de revisão; ou, por fim, no caso da obra copiada em exemplares e difundida para a ciência de todos.

No que tange ao registro da obra, o art. 673 do CC/1916, de modo diverso do art. 13 da Lei n. 996/1891, não condicionou o registro da obra para o gozo do direito, sendo claro ao dispor no parágrafo único que o registro induz presunção relativa de paternidade.

\footnotetext{
${ }^{76}$ BRASIL. Código Civil brasileiro. Rio de Janeiro: Jacintho Ribeiro dos Santos, 1916. Edição precedida de síntese histórica e crítica de Paulo Lacerda de Almeida.

${ }^{77}$ BRASIL. Código Civil brasileiro. Op. cit.
} 
Assim, o Código consagrou a proteção imediata da obra do autor. O caput do mesmo artigo diz: “[...] Para segurança do direito [...]”.

\subsubsection{A cessão de direito à paternidade}

O direito à paternidade é um direito moral de autor, não podendo ser alienado ou cedido por ser um direito da personalidade. No caso especial do plágio, a ofensa ao direito à paternidade é a sua usurpação. Por isso, vale registrar a cessão de direito à paternidade inserida no trâmite legislativo do Código Civil de 1916.

O Código Civil de 1916 sofreu uma injunção política ao acolher um dispositivo considerado uma anomalia no sistema autoral pátrio, conforme o próprio Clóvis Bevilacqua. ${ }^{78}$ Trata-se do art. 667 do CC/1916:

Art. 667. É suceptível de cessão o direito, que assiste o autor, de ligar o nome a todos os seus productos intellectuaes.

$\S 1^{\circ}$. Dará logar á indemnização por perdas e damnos a usurpação do nome do autor ou a sua substituição por outro, não havendo convenção que a legitime.

$\S 2^{\circ}$. O autor da usurpação, ou substituição, será, outrossim, obrigado a inserir na obra o nome do verdadeiro autor. ${ }^{79}$

Assim, institui-se o "ghost-writer" ou "nègre", prática antiga de colaboradores que vivem nos bastidores da criação literária. Não era o propósito de Clóvis Bevilacqua na redação original do Anteprojeto de Código Civil: “Art. 763. São pessoais e não podem ser cedidos: $1^{\circ}$. o direito de ligar seu nome a qualquer produto da sua inteligência" ${ }^{80}$ Isso se deveu à emenda do Deputado Arthur Lemos, que procurou justificar a sua intervenção na doutrina de Eugène Pouillet. ${ }^{81}$ De acordo com o registro dos trabalhos legislativos do Projeto de Código Civil:

[...] existem ainda hoje, e existirão sempre, obscuros operários das letras trabalhando sem êxito e se importando menos com a glória do que com dinheiro. Esses alugam a sua indústria e não podem reclamar sobre a obra por eles concebida e escrita, sob encomenda e por conta de terceiro, direito algum de propriedade. Tal direito pertence a quem lhe faz a

\footnotetext{
${ }^{78}$ BEVILACQUA, Clóvis. Direito das coisas. Op. cit., p. 287.

${ }^{79}$ Ibidem.

${ }^{80}$ Redação do Anteprojeto extraída de: SANTOS, J. M. Carvalho. Código Civil brasileiro interpretado. 5. ed. Rio de Janeiro: Freitas Bastos, 1953, v. 8, p. 477.

${ }^{81}$ BEVILACQUA, Clóvis. Direito das coisas. Op. cit., p. 287 e SANTOS, J. M. Carvalho. Op. cit., p. 478.
} 
encomenda. Semelhante convenção não seria certamente digna de louvor, mas nem por isso é ilícita. Ela deve, pois, ser cumprida como qualquer outra, pelas partes contratantes, salvo ao público o direito de denunciar a fraude, quando vier a descobri-la. Não será, de fato, extremo rigor impedir que um pobre diabo de algum talento adquira assim a subsistência, graças à vaidade, ridícula sem dúvida, mas não injurídica, do incapaz que quer passar como autor. ${ }^{82}$

O então deputado Arthur Lemos deu ares de juridicidade ao ato de renunciar, por meio de convenção, à paternidade de uma obra. Sabemos que o trâmite legislativo enseja muitos erros ou inserções de disposições equivocadas, sobretudo nos projetos de leis mais complexas como os códigos, quando os parlamentares fazem alterações no interesse de certos grupos ou no afã de demonstrar aos eleitores o cumprimento de seu mandato de forma erudita.

Cabe razão ao deputado Arthur Lemos tão somente no que tange à vaidade de pessoas que querem os louros do trabalho alheio. A par disso, ainda hoje existem profissionais que vivem sob o nome e a glória de vaidosos ou de nomes famosos e "vendáveis". É desproporcional e inconcebível a comparação de um criador intelectual, mesmo empregado ou subordinado, com um operário que apenas manipula máquinas ou outros instrumentos sem nenhuma criação própria. Ambos são profissionais. Mas autor é quem manifesta uma criação de seu espírito materializada em suporte sensível.

Conquanto o deputado Arthur Lemos não ignorasse "uma convenção não digna de louvor", inseriu no Projeto do Código Civil de 1916 uma prática intolerável ainda em nossos dias. A fé pública não pode ser iludida mediante a condescendência positivada no Código Civil ou em outro estatuto. Logo, é preciso ser prudente na elaboração de leis, desde o anteprojeto até a sanção presidencial, uma vez que se trata de um processo longo e muitas vezes passível de intervenções que podem tornar lícito o imoral ou reprovável.

Por seu turno, Pontes de Miranda, ao abordar o art. 667 do CC/1916 sob a designação de "cessão de direito autoral de nominação", elogia o legislador ao inserir o dispositivo em tela em nosso sistema jurídico. Para Pontes de Miranda, a ofensa não atinge o direito à paternidade, ou, na sua linguagem, direito autoral de nominação, lesando apenas o direito ao nome, dentro dos direitos da personalidade. Pontes de Miranda, a nosso

\footnotetext{
${ }^{82}$ SANTOS, J. M. Carvalho. Op. cit., p. 478.
} 
ver, parece não distinguir o direito ao nome do direito à paternidade, vendo neste somente um aspecto pecuniário da criação intelectual. ${ }^{83}$

Mais adiante, Pontes de Miranda repreende os juristas brasileiros que "foram vítimas de leituras estrangeiras" ${ }^{84}$ Ainda neste diapasão, Pontes de Miranda conclui que é uma questão examinada sem técnica segundo as injunções políticas das Convenções e "à fácil literatura das teses de doutoramento". ${ }^{85}$ Para terminar sua exposição, Pontes de Miranda diz que: "O princípio da incedibilidade do direito autoral de nominação é preconceito de classe, tanto que logo se abre conexão para os salariados (pré-contrato de cessão!)". ${ }^{86}$

Muito nos impressiona constatar na obra de jurista brasileiro de renome a defesa da renúncia de direito à paternidade mediante cessão. Não é um direito pecuniário, pois a cessão do direito de exploração da obra é objeto de contrato de edição, não sendo possível, pela própria natureza, a cessão de um direito moral de autor. Como nos referimos acima, a redação original do Anteprojeto de Código Civil de 1916 era completamente diferente. Vale ainda dizer que Pontes de Miranda, ao contrário de Clóvis Bevilácqua e Carvalho dos Santos, autores já citados, não faz nenhuma menção à intervenção legislativa de Arthur Lemos.

A obra é a projeção do espírito de uma pessoa, mesmo que seja lícito e tutelável o anonimato e a pseudonímia. Todavia, como já dissemos, não é tolerável justificar a ocultação de paternidade em prol de outrem. Tanto o anonimato quanto a pseudonímia são faculdades que o autor exerce por motivos pessoais ou em contextos nos quais não seja possível a livre manifestação de seus pensamentos.

Os escritores de bastidor ainda estão presentes, consoante Vittorio Maria De Sanctis, em muitos trabalhos acadêmicos, discursos parlamentares ou de executivos, autobiografias etc. Contudo, ainda diz esse autor, que, por ser um direito moral, não há

\footnotetext{
${ }^{83}$ PONTES DE MIRANDA, Francisco Cavalcanti. Tratado de Direito Privado. Rio de Janeiro: Borsoi, 1956, t. 16 , p. 59.

${ }^{84}$ Ibidem, p. 59.

${ }^{85}$ Ibidem, p. 60-61.

${ }^{86}$ Ibidem, p. 61.
} 
impedimento para que o "cedente de direito à paternidade" reivindique a qualquer momento a paternidade da obra. ${ }^{87}$

No que diz respeito à vigência do art. 667 do CC/1916, a Lei n. 5.988, de 14 de dezembro de 1973 — Lei Autoral —, no art. 134 diz que fica: “[...] ressalvada legislação especial que com ela for compatível". ${ }^{88}$ Ora, o Código Civil, em relação à Lei Autoral, é norma jurídica geral: lex specialis derogat generalis. Assim, cremos que a Lei n. 5.988/1973 revogou tacitamente as disposições sobre os direitos autorais presentes no Código Civil de 1916, em especial o artigo em exame, tanto por ser posterior e especial como por tratar da mesma matéria.

Por outro lado, ainda examinando a vigência do art. 667 do CC/1916, a Lei Autoral vigente - Lei n. 9.610, de 19 de fevereiro de 1998 - , revogou expressamente no art. 115 as disposições sobre direitos autorais do Código Civil de 1916, estatuto este vigente à época do início da vigência daquela lei. A renúncia do direito à paternidade por meio de contrato de cessão de direitos, consoante o $§ 1^{\circ}$ do art. 667 do CC/1916, cremos que poderia ser invocada sem óbices até o início da vigência da Lei n. 5.988/1973, ainda que esta tenha revogado o artigo em tela tacitamente. Logo, o cedente não poderia reivindicar a paternidade da obra.

Infere-se deste bosquejo histórico que em nenhum momento histórico houve a iniciativa de legislar sobre o plágio, muito embora a imoralidade do furto literário exista na consciência dos povos ocidentais há muitos séculos. As violações do direito autoral, tanto na Lei de Le Chapelier como no Código Criminal do Império e na Lei n. 496/1898, são denominadas de "contrafação". Além disso, a intervenção de um parlamentar no trâmite legislativo, como acabamos de abordar acima, pode causar consequências de difícil reparação, legitimando negócios sem amparo moral, não obstante lícitos por estarem baseados na letra da lei.

\footnotetext{
${ }^{87}$ DE SANCTIS, Vittorio Maria. I soggetti del Diritto d’Autore. 2. ed., Milano: Giuffrè, 2005, p. 134-135.

${ }^{88}$ BRASIL. Lei n. 5.988, de 14 de dezembro de 1973. Disponível em: <http://www6.senado.gov.br/ legislacao/ListaPublicacoes.action?id=122027\&tipoDocumento=LEI\&tipoTexto=PUB>. Acesso em: 06 jul. 2011. José Carlos da Costa Netto diz que tal artigo gerou incerteza por não identificar qual dispositivo legal estaria vigente. (COSTA NETTO, José Carlos. Op. cit., p. 66, nota de rodapé n. 51).
} 


\section{LEGISLAÇÃO AUTORAL BRASILEIRA: REVOGADA, VIGENTE, ANTEPROJETO DE LEI E PROJETO DE LEI}

\subsection{Lei revogada}

\subsubsection{Lei n. 5.988/1973: Lei sobre Direitos Autorais}

A Lei n. 5.988, de 14 de dezembro de 1973 - Lei sobre Direitos Autorais nasce num contexto de mudanças tecnológicas e culturais. ${ }^{89}$

Antes da Lei n. 5.988/1973 houve um Anteprojeto de Código de Direito de Autor e Conexos, dividido em 16 títulos, com 351 artigos, consoante José Carlos da Costa Netto. ${ }^{90}$ Contudo, o Anteprojeto de Código de Direito de Autor e Conexos foi revisado por iniciativa do então Ministro da Justiça, Luiz Antônio da Gama e Silva, sofrendo alterações propostas pelo antigo Ministro do Supremo Tribunal Federal, Candido da Mota Filho, que ofereceu um substitutivo de 98 artigos, sendo também oferecidos por outros membros da Comissão Revisora, Milton Sebastião Barbosa e Antonio Chaves, este especialista na matéria, um projeto de 198 artigos, ainda conforme o mesmo autor. Ambas as propostas não progrediram.

O então Procurador-Geral da República, José Carlos Moreira Alves, ficou incumbido de elaborar um novo Projeto, que veio a resultar na Lei n. 5.988/1973. A regulamentação da matéria, como veremos pela análise de algumas disposições, é mais bem exposta que no Código Civil de $1916 .^{91}$

As leis anteriores sobre a matéria autoral não a regulamentaram pormenorizadamente como a Lei n. 5.988/1973. Abaixo vamos comentar algumas novas disposições pertinentes a este trabalho.

$\mathrm{O}$ art. $3^{\circ}$ determina que os negócios jurídicos sobre direitos autorais se interpretam restritivamente. Vimos no capítulo anterior que tanto o Estatuto da Rainha Ana como a Lei

\footnotetext{
${ }^{89}$ BRASIL. Lei n. 5.988, de 14 de dezembro de 1973. Op. cit.

${ }^{90}$ COSTA NETTO, José Carlos. Op.cit., p. 66.

${ }^{91}$ Ibidem, p. 66.
} 
"Le Chapelier" deslocaram os direitos de exclusivo dos editores para os escritores, de modo que estes não ficassem tão vulneráveis aos interesses daqueles. Nesse sentido, a interpretação restrita visa proteger o autor de eventuais abusos de direitos morais e patrimoniais, ao contrário do disposto no art. 667 do Código Civil de 1916.

A seguir, o art. $4^{\circ}$ traz uma lista de definições em seus incisos, o que não foi feito nas leis anteriores. É bem conhecida a máxima de Javoleno que "omnis definitio in iure civili periculosa est" (D. 50.17.202), de modo que caberia mais à doutrina definir que ao legislador. No entanto, em certas matérias faz-se mister a definição legal para que não haja dúvidas, oferecendo maior segurança ao intérprete ao restringir o sentido de determinados vocábulos. Um exemplo disso está no inciso XII, do art. $4^{\circ}$, que define quem é artista: “[...] artista - ator, locutor, narrador, declamador, cantor, bailarino, músico, ou outro qualquer intérprete, ou executante de obra literária, artística ou científica”. Bem sabemos que o vocábulo "artista" também pode significar, de modo especial em artes plásticas, pintor, escultor e desenhista, ou, como constante na lei, intérprete e executante, sendo um vocábulo de sentido bem amplo.

Vale aqui transcrever a lição de Lógica Formal de Goffredo da Silva Telles Jr. sobre definição: "Oração imperfeita reveladora do que uma cousa é, ou do sentido de uma palavra". 92

Prossegue Goffredo da Silva Telles Jr. ao tratar da definição nominal, que mais nos interessa neste momento: "A definição nominal (do latim, nomen = nome) é a definição das palavras. Ela visa explicar o que se entende por um determinado vocábulo, tornando seu sentido claro, por meio de palavras mais conhecidas. $" 93$.

Ademais, vale aqui destacar o inciso IV, do art. $4^{\circ}$, no qual há a definição de reprodução é: "[...] a cópia de obra literária, artística e científica, bem como de fonograma.". O significado de "reprodução" nas leis brasileiras anteriores, brevemente analisadas no capítulo primeiro deste trabalho, sempre foi de "cópia". Entretanto, nenhuma das leis anteriores, bem como a Lei n. 5.988/1973, definiu o que é cópia. A par disso,

\footnotetext{
${ }^{92}$ TELLES JÚNIOR, Goffredo da Silva. Tratado da Conseqüiência: curso de lógica formal. São Paulo: José Bushatsky, 1962, p. 326. Itálicos no original.

${ }^{93}$ Ibidem, p. 328. Itálicos no original.
} 
Desbois, baseado na lei autoral francesa (Loi 11 mars 1957), distingue reprodução de cópia, restrita esta apenas para as obras de artes plásticas, enquanto que a reprodução para o restante das obras. ${ }^{94}$ Por outro enfoque, André Lucas, ao opinar sobre o posicionamento de Desbois, diz que uma interpretação nesse sentido parece um pouco intuitiva. ${ }^{95}$

Não é demais transcrever o significado jurídico de "cópia", uma vez que o sentido desta palavra não é muito preciso:

CÓPIA. Por sua derivação latina copia, de que se formou o adjetivo copioso (abundante), possui mais propriamente o sentido de abundância, riqueza, posses. Traz, ainda, a acepção de faculdade, permisssão, poder.

No entanto, na terminologia jurídica, não é este o seu significado técnico e corrente.

Serve o vocábulo para indicar o escrito ou papel em que se transcreve, palavra por palavra, tudo o que consta de outro escrito ou papel.

Atribuem o desvio na sua significação ao fato de, em sua aplicação com faculdade ou permissão, ser usado em várias frases jurídicas em que se firmava o princípio de poder transcrever ou a faculdade de transcrever o que era escrito em outro papel ou documento, tal como copiam describendi facere (dar a faculdade de transcrever).

Do copiam dare, copiam efficere, significando a permissão para o describere (transladar, transcrever), proveio a admissão de copia, como a própria translação, reprodução ou transcrição. E isto significa a reprodução literal de um escrito chamado original.

Assim sendo, a cópia se opõe ao original, de que é um duplicado ou uma reprodução. ${ }^{96}$

CÓPIA. Em sentido comum, significa a reprodução, ou imitação, de qualquer objeto ou documento.

Em sentido jurídico, cópia é a reprodução mecânica, ou eletrônica, ou gráfica, ou pictória, de um documento original. São espécies de cópias a certidão, o traslado, a pública-forma, e a contrafé, que mais não é do que uma cópia do mandado de citação, em direito processual [...]. ${ }^{97}$

Assim, a definição de cópia em relação à de reprodução é uma tautologia. Por isso, muito bem andou o legislador ao limitar o significado de reprodução na lei autoral. Por ser tautológico, tanto o vocábulo "cópia" como o vocábulo "reprodução" são usados para esclarecer um ao outro. Logo, uma definição legal, como dissemos acima, restringe o sentido da palavra de maneira a dar maior segurança ao intérprete na aplicação da lei.

\footnotetext{
${ }^{94}$ DESBOIS, Henri. Le droit d’auteur en france. Paris: Dalloz, 1966, p. 276.

${ }^{95}$ LUCAS, André; LUCAS, Henri-Jacques. Op. cit., p. 10.

96 SILVA, Oscar José de Plácido e. Vocabulário jurídico. 15. ed. Rio de Janeiro: Forense, 1998, p. 224. Negrito e itálicos no original.

${ }^{97}$ FRANÇA, Rubens Limongi (Coord.). Enciclopédia Saraiva do Direito. São Paulo: Saraiva, 1977, v. 20, p. 444. Negrito no original.
} 
Por sua vez, a definição de "contrafação", constante no inciso V do art. 4, é: “[...] a reprodução não autorizada."

Vimos no capítulo anterior que o vocábulo "contrafação" foi utilizado pela primeira vez na legislação autoral pátria no art. 350 do Código Penal de 1890, sem haver uma definição para a contrafação de obras literárias ou científicas, ao contrário das obras de artes plásticas e musicais, constantes nos três números do parágrafo único. Em seguida, a Lei n. 496/1898, ampliou o sentido de contrafação para toda violação de direitos de autor. Por fim, o Código Civil de 1916 não empregou o vocábulo "contrafação".

O sentido jurídico de contrafação é:

CONTRAFAÇÃO. Derivado do contrafazer, do baixo latim contrafacere (reproduzir por imitação), possui o vocábulo a significação de imitação fraudulenta, reprodução fraudulenta ou falsificação de qualquer ato ou coisa.

Desse modo, contrafação tanto se indica o ato fraudulento, em virtude do qual se procura imitar ou falsificar coisa, que se deseja inculcar como legítima, como significa a usurpação dolosa, ou a apresentação, como nossa, de obra literária ou artística, ou marca de outrem. ${ }^{98}$

CONTRAFAÇÃ̃o. Vocábulo derivado de contrafazer, do latim contrafacere, que significa reproduzir por imitação; imitação fraudulenta; reprodução clandestina ou falsificação de marcas de indústria, de comércio, obra literária, artística, ou científica etc.

A contrafação tanto indica o ato fraudulento que visa imitar ou falsificar alguma coisa, como também indica a usurpação dolosa de obra literária, artística ou científica, marca de indústria e de comércio, privilégio de invenção ou descoberta de outrem, e, como ato criminoso que é, é passível de sanções penais, bem como indenização na esfera civil.

Quando se trata de usurpação aos direitos de autor de obra literária, artística e científica, diz-se contrafação à obra, que pode revestir-se sob a forma de republicação abusiva. Na categoria de reprodução abusiva pode-se indicar outros casos que caracterizam a violação do direito autoral, como, p. ex., o plágio [...]. ${ }^{99}$

Dos verbetes acima transcritos, podemos pensar que contrafação é um meio ilícito de apresentar um ato ou coisa como se fosse verdadeiro. É revelar uma obra como sendo autêntica sem a aprovação do autor ou de um detentor de direitos deste. A par disso, dos

\footnotetext{
${ }^{98}$ SILVA, Oscar José de Plácido e. Op. cit., p. 216. Negrito e itálicos no original.

${ }^{99}$ FRANÇA, Rubens Limongi (Coord.). Enciclopédia Saraiva do Direito, v. 19, p. 121. Negrito e itálicos no original.
} 
verbetes também transcritos que buscam definir "cópia" podemos extrair que o sentido jurídico desta palavra surge da permissão contida em frases escritas em documentos. Consequentemente, a cópia seria somente a transcrição ou duplicação idêntica do original autorizada pelo autor.

O último verbete transcrito acima nos mostra que a reprodução abusiva enseja o plágio. Cremos que a Comissão de Redação da Enciclopédia Saraiva do Direito tenha pensado que o plágio seja uma violação de direito autoral de difícil enquadramento, pois cita como exemplo de outros casos. Logo, de acordo com esse verbete, pensamos que o plágio se insere na usurpação dolosa.

O legislador, ao definir contrafação, restringiu o significado do vocábulo se compararmos com as leis anteriores. Desse modo, outras violações de direito de autor, v.g., a representação ou execução de obra sem autorização do autor, não são contrafação. Logo, contrafação de acordo com a Lei n. 5.988/1973 é somente a cópia não autorizada, uma espécie de violação de direito de autor.

A Lei n. 5.988/1973 também exemplificou as obras protegidas no art. $6^{\circ}$, o que não havia sido feito nas leis anteriores. Bem andou o legislador ao enumerar um rol exemplificativo, pois permitiu que novas espécies de obras ou suportes, até então não existentes, pudessem ter a proteção autoral. Por seu turno, o art. 11 diz o que não é passível de proteção autoral. A ocorrência do plágio, como veremos adiante, somente é possível se se tratar de uma obra protegida pelo direito de autor.

Não existente na regulamentação anterior é a proteção do título, conforme o art. 10. Todavia, a proteção do título está condicionada à comparação de obra do mesmo gênero, bem como à anterioridade da publicação.

Outra mudança advinda na Lei n. 5.988/1973, não trazida nas leis anteriores, é a disciplina sobre a identificação do autor de obra intelectual. $\mathrm{O}$ art. 12 diz que autor é quem usa o nome ou pseudônimo ou ainda um sinal, e o art. 13 o complementa ao dispor sobre o escopo de paternidade da obra. Ainda, nos termos do parágrafo único do art. 13, quando não houver a indicação de paternidade considera-se autor o utente da obra em público. 
Além disso, o art. 15 dispõe sobre a pessoa jurídica autora, quando esta organizar a obra. Tal disposição não foi tratada no Código Civil de 1916. Entretanto, a lei não definiu a obra coletiva, como fez com a obra em colaboração, na alínea "a" do inciso VI do art. $4^{\circ}$.

Na mesma linha do art. 673 do Código Civil de 1916, o art. 17 da Lei n. 5.988/1973 destaca que a tutela da obra independe de registro, cujo escopo é assegurar os direitos de autor.

Também enumerou no art. 25, sem esgotar, os direitos morais de autor, não disciplinando dessa maneira o Código Civil de 1916 e outras leis anteriores. Aliás, vimos que no Código Civil de 1916, no art. 667, havia uma disposição totalmente contrária aos direitos morais de autor: a cessão de paternidade.

Dentre as limitações aos direitos de autor, destacamos a limitação da cópia privada de qualquer obra em um exemplar sem o escopo de lucro, constante no inciso II do art. 49. Também o art. 50, que garante a liberdade de criação de paráfrases e paródias, obras derivadas, sendo lícitas se não forem reprodução ou atentarem contra as obras originárias.

O parágrafo único do art. 64 diz que se houver repetição na numeração dos exemplares de obra, ausência de numeração ou numeração excedente ao estipulado em contrato de edição, tais atos são considerados contrafação, devendo o editor pagar perdas e danos ao autor. Nesse sentido, cremos que a contrafação se restringe ao sentido de cópias exatas, no todo ou em parte, de exemplares.

Na sequência, o art. 67 veda ao editor a inserção de alterações na obra sem a permissão do autor. Da relação entre o autor e editor faz-se mister um diálogo permanente durante o processo de edição e posteriormente na publicação e venda dos exemplares.

O Título VII da Lei n. 5.988/1973 criou o Conselho Nacional de Direito Autoral (CNDA). O art. 116 da lei diz que a finalidade do Conselho é fiscalizar, dar consulta e assistência aos autores, intérpretes e executantes. O Conselho funcionou durante 14 anos, sendo extinto em 1990 pelo então Presidente da República Fernando Collor de Mello. ${ }^{100}$

${ }^{100}$ COSTA NETTO, José Carlos. Op. cit., p. 257. 
No que tange às violações de direito de autor, o diploma legal de 1973 completa as disposições do Código Civil de 1916. De modo diverso deste estatuto, a Lei n. 5.988/1973, no art. 121, é clara ao dispor que as sanções civis não excluem as penais. Por seu turno, o art. 122 traz disposição semelhante ao art. 669 do CC/1916, mas aumentando a sanção, no caso de não se conhecer o número de exemplares, no valor de mil exemplares para dois mil. Ressalta-se o art. 126, que no caput impõe danos morais e a indicação do autor, em caso de ausência desta. Além disso, a alínea "b" obriga a inclusão de errata nos exemplares não distribuídos e também a comunicação destacada em jornal de grande circulação no domicílio do autor e do editor por três vezes consecutivas.

Portanto, a Lei n. 5.988/1973 melhorou a regulamentação da matéria autoral, porém não incluiu explicitamente, mediante tipificação, o plágio. A contrafação passa de gênero de violação de direito de autor para espécie.

\subsection{Leis vigentes}

\subsubsection{Código Penal brasileiro de 1940 e sucessivas alterações}

O Código Penal vigente — Decreto-lei n. 2.848, de 7 de dezembro de 1940 tratou das violações de direito autoral na Parte Especial, Título III (Dos crimes contra a propriedade imaterial), Capítulo I (Dos crimes contra a propriedade intelectual), artigos 184,185 e 186.

A matéria foi regulamentada no Código Penal de 1890 em 9 artigos e, no Código Penal de 1940, passou para 3 artigos. Cremos que isto se deve ao fato de não haver à época da redação do Código Penal de 1890 uma lei específica sobre o Direito Autoral. Por isso, era necessário ter uma disciplina mais exaustiva sobre as violações de direito autoral.

Outrossim, o Código Penal de 1940, semelhantemente ao Código Penal de 1890, surgiu no momento de nova ordem política: o Estado Novo. Pierangeli nos relata que José de Alcântara Machado D’Oliveira foi incumbido por Francisco Campos, Ministro da Justiça, de elaborar um Anteprojeto de Código Penal. Contudo, o Anteprojeto apresentado por Alcântara Machado, em abril de 1940, foi revisado por uma comissão presidida pelo 
Ministro da Justiça e composta por Vieira Braga, Nélson Hungria, Narcélio de Queiroz e Roberto Lyra. Destaca Pirangeli que Alcântara Machado tomou conhecimento das alterações feitas pela comissão após a publicação pela imprensa. Embora tenha sido alterado o Anteprojeto pela comissão, Nelson Hungria, ainda conforme o relato de Pierangeli, dizia que “o Projeto Alcântara Machado está para o Código Penal de 1940 como o Projeto Clóvis está para o Código Civil”. ${ }^{101}$

De maneira diversa do Código Penal de 1890, o Código Penal de 1940, em seu art. 184, tipifica o crime de violação de direito autoral somente dizendo no caput: “Art. 184. Violar direito de autor de obra literária, científica ou artística" ${ }^{102}$ Preferiu o legislador não definir a violação de direito autoral, criando uma norma penal em branco.

As normas penais em branco têm sanção penal, mas dependem de disposição constante em outra norma jurídica. As violações de direito autoral estão expostas em lei especial, como a Lei n. 5.988/1973 e a vigente Lei n. 9.610/1998, ou em parte de lei geral, como no Código Civil de 1916. Pensamos que foi uma boa opção legislativa, pois a seara autoral é específica e com muitas particularidades.

No entanto, as normas penais em branco suscitam o problema da aplicação da pena, uma vez que o conteúdo da norma penal depende de outra norma jurídica, principalmente no que se refere à norma penal mais benigna. ${ }^{103}$ Podemos exemplificar com a hipótese de alguém que venha a reproduzir mais de um exemplar de obra protegida, sem autorização do autor, mesmo para distribuição gratuita, e acabe por ser beneficiado por norma jurídica posterior que exclua o ato das violações e o insira nas limitações aos direitos autorais.

Por outro lado, o art. 185, do Código Penal de 1940, tipifica o crime de usurpação de nome ou pseudônimo alheio, não sendo uma norma penal em branco. Trata-se aqui de ato inverso ao plágio: o ofensor geralmente utiliza o nome ou a indicação, em seus trabalhos, de pessoa renomada, de maneira a enganar a todos. A pena cominada é maior que a violação de direito autoral. É fato mais ocorrente em obras de artes plásticas, v.g., um

\footnotetext{
${ }^{101}$ PIERANGELI, José Henrique. Op. cit., p. 78-80.

102 BRASIL. Código Penal: Decreto-Lei n. 2.848, de 07 de dezembro de 1940. Disponível em: $<$ http://www6.senado.gov.br/legislacao/ListaPublicacoes.action?id=102343\&tipoDocumento=DEL\&tipoTex to=PUB $>$. Acesso em 30 set. 2011.

103 TOLEDO, Francisco de Assis. Op. cit., p. 43.
} 
autor goza de boa reputação e suas obras têm um valor pecuniário alto. Entretanto, autores de obras literárias podem ser vítimas desse crime, sobretudo hoje, com a rede mundial de computadores (Internet), na qual muitas pessoas, para sustentar os seus argumentos, criam comentários nunca ditos pelos autores.

Em seguida, o art. 186, dispõe sobre a ação penal privada para os crimes contra os direitos autorais, exceto se houver prejuízo para entidade de direito público. Trata-se da ação penal privada exclusiva, que só pode ser ajuizada pelo ofendido ou seu representante legal.

A Lei n. 6.895, de 17 dezembro de 1980, veio a dar nova redação aos artigos 184 e 186. Acrescentou dois parágrafos no art. 184. O caput passou a ser: “Art. 184. Violar direito autoral". ${ }^{104}$ Pensamos que a alteração do caput foi feita para incluir os direitos conexos de direito de autor sob a denominação mais abrangente de "direito autoral". $\mathrm{O} \S 1^{\circ}$ do art. 184 dispõe sobre a reprodução não autorizada para fins de comércio, adicionando o fonograma e o videograma, bem como impondo pena de reclusão de um ano a quatro anos e multa em valor fixo na moeda da época. Ademais, o $\S 2^{\circ}$ tem redação semelhante ao parágrafo único do art. 184, na primeira redação, cominando a mesma pena do $\S 1^{\circ}$. Em seguida, o art. 186 passou a incluir, além de entidade de direito público, outras pessoas jurídicas de direito público: a autarquia, a empresa pública, a sociedade de economia mista e a fundação de direito público.

Da mesma forma que a redação de 1940 do art. 184, não houve a inserção do vocábulo "contrafação" para designar toda violação ao direito autoral, sendo óbvio tal opção tendo em vista que a Lei n. 5.988/1973 já o definira. Todavia, o plágio também não foi incluído explicitamente entre as violações de direito de autor.

Federico Andrés Villalba Díaz, em estudo dedicado ao aspecto penal do plágio, destaca o dolo como elemento subjetivo do plágio, embora não exista na legislação argentina uma definição de plágio. O dolo deve ser comissivo, pois a lei autoral argentina

\footnotetext{
${ }^{104}$ BRASIL. Decreto n. 6.583, de 29 de setembro de 2009. Disponível em: <http://www.planalto.gov.br/ ccivil_03/_Ato2007-2010/2008/Decreto/D6583.htm>. Acesso em: 06 dez. 2012. Promulga o Acordo Ortográfico da Língua Portuguesa, assinado em Lisboa, em 16 de dezembro de 1990.
} 
não contempla o dolo por omissão. ${ }^{105}$ Entre nós, Paulo José da Costa Jr. também afirma que o dolo é o elemento subjetivo da violação de direito autoral, consoante o art. 180 do Código Penal, sendo excluído o erro do agente. ${ }^{106}$

Na sequência das alterações do art. 184, a Lei n. 8.635, de 16 de março de 1986, atualizou o valor monetário da pena de multa, bem como acrescentou o $\S 3^{\circ}$, que obriga o juiz a determinar, em caso de condenação, a destruição de objetos elaborados em violação de direito de autor.

Por fim, a última alteração introduzida no Capítulo I do Título III da Parte Especial do Código Penal.

O caput, do art. 184, foi alterado para: "Art. 184. Violar direito de autor e os que lhe são conexos". ${ }^{107}$ Como dissemos sobre a alteração feita pela Lei n.n. 6.895/1980, a alteração visou inserir os direitos conexos de autor, o que está mais claro nessa alteração.

Foram acrescidas, nos parágrafos do art. 184, disposições sobre os direitos de intérpretes e executantes, em consonância com o caput do mesmo artigo. O $\S 3^{\circ}$ passou a ter nova redação para incluir o oferecimento ao público através de novos meios tecnológicos, como o cabo, a fibra ótica ou o satélite, mais precisamente por empresas de televisão por assinatura. A pena cominada no $§ 3^{\circ}$ é a mesma dos parágrafos anteriores.

$\mathrm{O} \S 4^{\circ}$ diz que não são aplicáveis todos os parágrafos anteriores se ocorrer um fato dentro das limitações de direito de autor e conexos. Ressalta-se a inclusão da limitação da cópia em um exemplar para uso privado, que não foi tratada desta maneira na Lei n. 9.610/1998, como veremos no próximo tópico.

A Lei n. 10.695/2003 inovou ao ampliar a ação penal incondicionada. Até aqui era somente ação penal privada exclusiva, isto é, só por meio da queixa. Agora, o art. 186, além da ampliação do rol das pessoas jurídicas nas alterações anteriores, passa a estar

\footnotetext{
${ }^{105}$ VILLALBA DÍAZ, Federico Andrés. ¿Quando el Plagio es Delito? 117 p. 2012. Dissertação (Mestrado em Direito Penal) - Faculdad de Derecho, Universidad de Palermo, Buenos Aires, 2012, p. 99.

${ }^{106}$ COSTA JÚNIOR, Paulo José da. Direito Penal Objetivo. 3. ed. Rio de Janeiro: Forense Universitária, 2003 , p. 367.

${ }^{107}$ BRASIL. Lei n. 10.695, de $\mathbf{1}^{\mathbf{0}}$ de julho de 2003. Disponível em: <http://www6.senado.gov.br/legislacao/ ListaPublicacoes.action?id=236928\&tipoDocumento=LEI\&tipoTexto=PUB> Acessado em 12 out. 2011.
} 
dividido em 4 incisos. Os crimes do caput são processados mediante queixa, enquanto que os crimes do $\S \S 1^{\circ}$ e $2^{\circ}$ do art. 184 mediante ação penal pública incondicionada, bem como o crime do $\S 3^{\circ}$ do art. 184 por meio de ação penal pública condicionada à representação. Conclui-se que o Ministério Público passou, nos casos de ação penal incondicionada, a ter legitimidade para propor a ação penal independentemente do interesse de agir do fendido.

Vale aqui também mencionar as alterações inseridas no art. 530 do Código de Processo Penal, pela Lei n. 10.695/2003, no fito introduzir um procedimento cautelar de busca e apreensão (arts. 530-A usque 530-I do CPP) especialmente para os crimes tipificados nos parágrafos do art. 184 do CP.

Isso tem uma razão de ser: a legitimidade do Ministério Público para ser titular de ação penal em crimes contra os direitos de autor e conexos é um viés da política contra a "pirataria", posto que o avanço tecnológico proporcionou um meio mais eficiente para aumentar o número de exemplares reproduzidos sem a autorização do autor, principalmente de obras cinematográficas e musicais, sem esquecer os programas de computador. Por sua vez, o acesso aos meios informáticos de reprodução não tem grandes obstáculos, além de haver a Internet, onde há uma infinidade de conteúdos para acessar e compartilhar.

Além disso, nosso país é signatário do Acordo Constitutivo da Organização Mundial do Comércio - OMC, em especial, o Anexo 1C - Acordo sobre Aspectos dos Direitos de Propriedade Intelectual Relacionados ao Comércio (TRIPS), recepcionado em nosso ordenamento jurídico pelo Decreto n. 1.355, de 30 de dezembro de 1994. Esse acordo, que examinaremos com mais vagar no próximo capítulo, tem o escopo de coibir os atos de falsificação e outros delitos contra a propriedade industrial e os direitos de autor e conexos. Por isso, o Ministério Público foi inserido numa política internacional de combate à pirataria.

$\mathrm{O}$ art. 185, do CP, foi revogado expressamente pela Lei n. 10.695/2003. Pensamos que o crime de usurpação de nome ou pseudônimo alheio foi incorporado no tipo penal mais amplo do caput do art. 184: violação de direito autoral. Assim, não exaurindo as hipóteses de violação de direito de autor e conexos em norma penal, por exclusão, apenas os crimes constantes nos parágrafos do art. 184 são condutas tipificadas de violação de 
direito autoral no Código Penal. Nessa vereda, se ocorrer a violação de usurpação de nome ou pseudônimo alheio, a pena será menor que a anteriormente cominada, ao passo que nos crimes dos parágrafos a pena é maior: "reclusão de 2 (dois) a 4 (quatro) anos, e multa". 108 Logo, inferimos que a opção legislativa foi reforçar a sanção aos atos ilícitos de comércio de reproduções e oferecimento ao público sem a autorização de autor ou intérprete e executante.

Portanto, o Código Penal de 1940 regulamentou a matéria autoral de maneira mais sistemática que o diploma penal anterior. Em linhas gerais, as sucessivas alterações não modificaram o âmago da regulamentação, principalmente o caput do art. 184, que sempre foi mantido como norma penal em branco. Contudo, a Lei n. 10.695/2003 fez alterações significativas ao legitimar o Ministério Público, além das hipóteses de pessoas jurídicas de direito público, passando o interesse de agir do âmbito privado para o público, num contexto de repressão à dita pirataria. A Lei n. 10.695/2003 buscou adequar a legislação às novas tecnologias, v.g., oferta ao público através de fibra ótica ou satélites. No caso da revogação do crime de usurpação de nome ou pseudônimo alheio, cremos que a maior ofensa atinge o direito à paternidade, uma vez que se atribui autoria de obra não criada pelo autor falsamente indicado, sem olvidar o prejuízo econômico. Da mesma forma, o plágio e a contrafação não foram tipificados como crime, o que nos remete à lei específica autoral.

\subsubsection{Lei n. 9.610/1998: Lei sobre Direitos Autorais}

A Lei n. 9.610, de 19 de fevereiro de 1998, em seu preâmbulo, enuncia que: “Altera, atualiza e consolida a legislação sobre direitos autorais e dá outras providências". ${ }^{109}$ A lei vigente segue a mesma estrutura da Lei n. 5.988/1973.

O país, no momento da apresentação do Projeto de Lei n. 5.430, de 1990, em 6 de agosto de 1990, já se encontrava em novo cenário político, pois a Constituição Federal de 1988 inaugurou uma nova fase, denominada de Nova República. Por isso, para regulamentar o disposto no inciso XXVII do art. $5^{\circ}$ da Constituição Federal de 1988, o

\footnotetext{
${ }^{108}$ BRASIL. Lei n. 10.695, de $1^{\circ}$ de julho de 2003. Op. cit.

109 BRASIL. Coletânea de Legislação de Comunicação Social. 7. ed. São Paulo: RT, 2010. Revisão e atualização Marcos Alberto Sant'Anna Bitelli.
} 
Senador Luiz Viana Filho apresentou o Projeto de Lei n. 5.430/1990, que, após alterações no trâmite legislativo, tornou-se a lei autoral vigente. ${ }^{110}$

Sobre o trâmite do Projeto de Lei n. 5.430/1990, José Carlos da Costa Netto nos relata que o Deputado Roberto Brant foi incumbido de presidir uma comissão para emitir parecer sobre o Projeto de Lei n. 5.430/1990, sendo relator o Deputado Aloysio Nunes Ferreira. Em 10 de setembro de 1997, a comissão apresentou o parecer. ${ }^{111}$

Ademais, desde a apresentação do Projeto de Lei n. 5.430/1990 até a publicação da Lei n. 9.610/1998, novas tecnologias vieram ao público, sendo emblemático o caso da rede mundial de computadores (Internet), cujo acesso ao público geral iniciou-se no ano de 1995. Em consonância com essas transformações, o Projeto de Lei n. 5.430/1990 sofreu inúmeras alterações, de maneira a acrescentar novos meios tecnológicos inicialmente não contemplados. ${ }^{112}$ A adesão do Brasil ao Acordo Constitutivo da Organização Mundial do Comércio, sobretudo o Anexo 1C (TRIPS), como vimos no item anterior, também motivou o debate legislativo de modo a harmonizar a nossa legislação ao tratado.

Em linhas gerais, vamos tecer um breve comentário das alterações trazidas pela Lei n. 9.610/1998, sobretudo no que tange ao nosso estudo.

A definição de "reprodução", do inciso IV do art. 4 da Lei n. 5.988/1973, no Projeto de Lei n. 5.430/1990, não foi alterada. No entanto, passou a ser, no inciso VI do art. $5^{\circ}$ da Lei n. 9.610/1998, mais ampla, especificando ser a cópia em exemplares de uma obra, ao invés de unicamente obra, bem como acrescentando outros suportes tangíveis, "incluindo qualquer armazenamento permanente ou temporário por meios eletrônicos ou qualquer outro meio de fixação que venha a ser desenvolvido”.

A propósito da reprodução e o computador, Ascensão diz que a inserção de uma obra em formato digital no computador é mais uma questão de direito de fixação do que

\footnotetext{
${ }^{110}$ BRASIL. Projeto de Lei n. 5.430, de 1990. Disponível em: <http://www.camara.gov.br/proposicoesWeb/ fichadetramitacao?idProposicao=227532>. Acesso em: 20 out. 2011.

${ }_{111}^{11}$ COSTA NETTO, José Carlos. Op. cit., p. 71.

112 Cf. BRASIL. Projeto de Lei n. 5.430, de 1990. Altera, atualiza e consolida a legislação sobre direitos autorais e dá outras providências. Diário do Congresso Nacional da República Federativa do Brasil, seção 1, ano 45, n. 84. Brasília, DF, 7 ago. 1990, p. 8.720-8.727.
} 
direito de reprodução. ${ }^{113}$ Ascensão afirma, com fulcro na Lei n. 5.988/1973, respectivamente nos incisos VII e VIII do art. 4", que a lei brasileira difere "fixação" de "reprodução", ao contrário da Convenção de Berna, que, no número 3 do art. 9º define gravação sonora e visual como reprodução. ${ }^{114}$ A Lei n. 9.610/1998 mantém a distinção entre reprodução e fixação, sendo esta cabível para a obra audiovisual (alínea "i” do inciso VIII do art. $5^{\circ}$ ) e o fonograma (inciso IX do art. $5^{\circ}$ ). Logo, está claro que Ascensão quer enfatizar o registro de uma obra em elaboração e a inserção de uma obra em formato digital, tanto no disco rígido do computador como em outro suporte.

De fato, o computador, como outras tecnologias surgidas no passado, traz consigo novos problemas. O computador permite, por meio de programas cada vez mais aperfeiçoados, a reprodução de obras em velocidade maior que outros meios. Um exemplo disso é o envio de cópias de arquivos, ou, como se diz em Portugal, de ficheiros, por meio de correio eletrônico: a reprodução é quase instantânea. Aliás, no disco rígido do computador ou em outro suporte de documentos digitais é possível fixar, permanentemente ou temporariamente, diversos tipos de obras - no nosso caso, a obra literária escrita ou oral.

A Lei n. 9.610/1998, por seu turno, não definiu bem, a nosso ver, a obra audiovisual, na alínea "i”" do inciso VIII do art. 5. Ao empregar na definição um vocábulo já definido na mesma lei, o legislador não foi claro ao dispor que a obra audiovisual "tenha a finalidade de criar, por meio de sua reprodução, a impressão de movimento". Não está claro se se trata de uma cópia, consoante a definição de reprodução do inciso VI do art. $5^{\circ}$. Seria melhor, ao invés de "reprodução", usar as palavras "execução" ou "exibição", ambas não definidas na lei.

A definição de "contrafação", no inciso VIII do art. 5, permanece a mesma do art. $4^{\circ}$ da Lei n. 5.988/1973: “[...] a reprodução não autorizada.”.

O art. $8^{\circ}$ da Lei n. 9.610/1998 ampliou o rol de objetos não protegidos pelo Direito Autoral, não demonstrando exceção apenas aos atos oficiais, como no art. 11 da Lei n. 5.988/1973. Ressalta-se o inciso I do art. $8^{\circ}$ da Lei n. 9.610/1998, que dispõe que as ideias

\footnotetext{
113 ASCENSÃO, José de Oliveira. Op. cit., p. 690.

${ }^{114}$ Ibidem, p. 171.
} 
não são passíveis de proteção autoral. Muitas acusações de plágio, independentemente da natureza obra, são lastreadas no grande equívoco de usurpação de ideias. Também destacamos o inciso II do art. $8^{\circ}$, segundo o qual "as regras para realizar atos mentais" também não são passíveis de tutela autoral, como veremos em capítulo dedicado aos critérios de proteção da obra. Em seguida, o inciso VI do art. $8^{\circ}$ exclui da proteção autoral os nomes e títulos isolados.

Por seu turno, a redação do art. 10 da Lei n. 9.610/1998, sobre a proteção do título, permanece a mesma do art. 10 da Lei n. 5.988/1973.

$\mathrm{O}$ art. 11 da Lei n. 9.610/1998 define quem é o autor, o que não havia na Lei $\mathrm{n}$. 5.988/1973: “Art. 11. Autor é pessoa física criadora de obra literária, artística ou científica”.

A titularidade de pessoa jurídica como autora quase que foi suprimida de nossa legislação. Não obstante isso, a titularidade de autora da pessoa jurídica foi disciplinada de modo não tão preciso como no art. 15 da Lei n. 5.988/1973. O parágrafo único do art. 11 manteve a titularidade da pessoa jurídica, ao dizer que a proteção "poderá aplicar-se às pessoas jurídicas nos casos previstos nesta lei”.

Antonio Carlos Morato, em obra dedicada ao estudo da titularidade de direitos de autor da pessoa jurídica e na obra coletiva, nos relata que a exclusão da pessoa jurídica autora foi tentada nos Projetos de Lei. ${ }^{115}$ Com efeito, no Projeto de Lei n. 5.430/1990, o art. 15 foi alterado, sem expor bem como no artigo de mesmo número na Lei n. $5.988 / 1973$, indicando apenas no $\S 3^{\circ}$ que ao organizador de obra coletiva cabe a titularidade de direitos patrimoniais. ${ }^{116}$

\footnotetext{
115 MORATO, Antonio Carlos. Direito de Autor em obra coletiva. São Paulo: Saraiva, 2007, p. 121.

${ }^{116}$ BRASIL. Projeto de Lei n. 5.430, de 1990. Diário do Congresso Nacional da República Federativa do Brasil. Op. cit., p. 8.721. A redação do art. 15, no Projeto de Lei n. 5.430/1990, é: “Art. 15. É assegurada a proteção às contribuições individuais em obras coletivas e compósitas, em cuja publicação, por qualquer forma, meio ou processo, deverão ser respeitados os direitos morais e patrimoniais de seus direitos. $\S 1^{\circ}$. Ao participante da obra coletiva, cuja contribuição possa ser utilizada separadamente, são asseguradas todas as faculdades inerentes à sua criação como obra individual, vedada, porém, a utilização que possa acarretar prejuízo à exploração da obra coletiva. $\S 2^{\circ}$. Qualquer dos participantes, no exercício de seus direitos morais, poderá proibir que se indique ou anuncie seu nome na obra coletiva, sem prejuízo do direito de haver a remuneração contratada. $\S 3^{\circ}$. Cabe ao organizador a titularidade dos direitos patrimoniais de autor sobre o conjunto da obra coletiva ou da obra compósita. $\S 4^{\circ}$. O contrato com o organizador especificará a
} 
O Projeto de Lei n. 2.951, de 1992, de autoria do Deputado José Genuino, anexado ao Projeto de Lei n. 5.430/1990, enfrentou com objetividade a regulamentação da obra coletiva, de acordo com Antonio Carlos Morato. Dessa maneira, a lei vigente passou a suscitar mais dúvidas sobre a obra coletiva que a lei anterior. ${ }^{117}$

Sobre as limitações aos direitos autorais, a cópia privada ficou restrita a pequenos trechos, como dispõe o inciso II do art. 46, o que não ocorria no inciso II do art. 49 da Lei n. 5.988/1973, sendo esta mais ampla ao expor que não constituía ofensa a reprodução "de qualquer obra" em um só exemplar sem o fito de lucro. A redação do inciso II do art. 49 do Projeto de Lei n. 5.430/1990 acrescenta, além de qualquer obra, qualquer produção. ${ }^{118}$

Cremos que a redação da limitação da cópia privada estava mais bem disciplinada na lei anterior porque não se limitava a pequenos trechos. Bem sabemos que há muitas situações que nos impelem a extrair uma cópia de uma obra por não termos outros meios lícitos, v.g., uma obra literária em forma de livro de edição esgotada há muito tempo. Outra hipótese é a extração de cópia para fim de estudo ou crítica, não sendo possível o exercício dessa atividade só com a reprodução de pequenos trechos.

As violações do direito autoral sofreram alterações. O parágrafo único do art. 103 aumenta para o valor de três mil exemplares quando não se conhecer o número destes. $\mathrm{O}$ art. 105 trata da transmissão não autorizada de obras, que é apenada com suspensão imediata e multa diária, podendo ser a multa até o dobro na hipótese de não se saber se o infrator é reincidente. Por sua vez, o art. 107 adiciona disposições relativas às violações mediante a utilização de novas tecnologias.

Portanto, a Lei n. 9.610/1998 realizou algumas alterações na Lei n. 5.988/1973, sendo que em alguns pontos não melhorou, v.g., a limitação de cópia de pequenos trechos num exemplar. Introduziu novas disposições em sintonia com novos meios tecnológicos para elaboração de obras intelectuais e a sua difusão. Aqui também não há uma exposição

contribuição do participante, o prazo para entrega ou realização, a remuneração e demais condições para sua execução.".

${ }^{117}$ MORATO, Antonio Carlos. Op. cit. p. 122.

${ }^{118}$ BRASIL. Projeto de Lei n. 5.430, de 1990. Diário do Congresso Nacional da República Federativa do Brasil. Op. cit., p. 8.721. 
sobre a violação de direito de autor denominada plágio, nem outra definição legal de contrafação.

\subsection{Anteprojeto de lei e projeto de lei}

\subsubsection{Anteprojeto de lei sobre Direitos Autorais}

O Anteprojeto de Lei do Ministério da Cultura visa à alteração, atualização e consolidação das leis autorais. Foi colocado em consulta pública entre 25 de abril e 30 de maio de 2010, momento em que recebeu inúmeras contribuições da sociedade. Antes de ser encaminhado à Casa Civil da Presidência da República, a Ministra Anna Maria Buarque de Hollanda submeteu o Anteprojeto à análise do Grupo Interministerial da Propriedade Intelectual (GIPI). O Anteprojeto foi encaminhado à Casa Civil da Presidência da República em 31 de outubro de $2011 .^{119}$

O parágrafo único acrescido ao art. $1^{\circ}$ no Anteprojeto de Lei traz disposições presentes na Constituição Federal. ${ }^{120}$ Cremos ser descabida a inserção das disposições do parágrafo único, posto que a Constituição já garante os direitos fundamentais e sociais.

Foram acrescidos ao art. $4^{\mathrm{o}}$ após consulta pública, quatro parágrafos. ${ }^{121}$ O Código Civil de 2002 trata das matérias inseridas nos parágrafos do art. $4^{\circ}$, não havendo mister de

119 BRASIL. Ministério da Cultura. Acessoria de Comunicação. Direito Autoral: Anteprojeto seguiu para Casa Civil depois de incorporar contribuições da sociedade. 9 jan. 2012. Disponível em: <http://www.cultura.gov.br/site/2012/01/09/134950>. Acesso em: 12 jan. 2012.

120 "Parágrafo único. A interpretação e a aplicação desta Lei atenderão às finalidades de estimular a criação intelectual e a diversidade cultural e garantir a liberdade de expressão e orientar-se-ão pelos ditames constitucionais de proteção aos direitos autorais em equilíbrio com os demais direitos fundamentais e os direitos sociais" (BRASIL. Ministério da Cultura. Anteprojeto de Lei de Modernização da Lei Autoral: tabela comparativa das propostas de revisão da Lei de Direito Autoral. Disponível em: <http://www.cultura.gov.br/site/wp-content/uploads/2011/04/LDA_-tabela_-

compara_versoes_PosGIPI.pdf>. Acesso em: 16 out. 2011).

121 "Art. $4^{\circ}$. Os negócios jurídicos relativos aos direitos autorais devem ser interpretados restritivamente, de forma a atender á finalidade específica para a qual foram celebrados. $\S 1^{\circ}$. Nos contratos realizados com base nesta Lei, as partes contratantes são obrigadas a observar, durante a sua execução, bem como em sua conclusão, os princípios da probidade e da boa-fé, cooperando mutuamente para o cumprimento da função social do contrato e para a satisfação de sua finalidade e das expectativas comuns e de cada uma das partes. $\S$ 2o. Nos contratos de execução continuada ou diferida, qualquer uma das partes poderá pleitear sua revisão ou resolução, por onerosidade excessiva, quando para a outra parte decorrer extrema vantagem em virtude de acontecimentos extraordinários e imprevisíveis. § 3o. É anulável o contrato quando o titular de direitos autorais, sob premente necessidade, ou por inexperiência, tenha se obrigado a prestação manifestamente desproporcional ao valor da prestação oposta, podendo não ser decretada a anulação do negócio se for oferecido suplemento suficiente, ou se a parte favorecida concordar com a redução do proveito. $\S 4^{\circ}$. No contrato de adesão adotar-se-á a interpretação mais favorável ao autor.”. (Ibidem). 
nova disciplina em lei específica. Vale lembrar que o Código Civil em relação à lei autoral é norma geral, isto é, nas eventuais lacunas existentes na lei autoral aplicam-se as disposições do Código Civil. Teria sentido a inserção dos parágrafos se o Anteprojeto fosse concebido antes da sanção presidencial do Código Civil de 2002, pois as disposições dos parágrafos não constavam no Código Civil de 1916. Outrossim, o art. 113B do Anteprojeto de Lei, inserido após a consulta pública, determina de modo expresso a aplicação subsidiária do Código Civil.

Dessa maneira, é totalmente desnecessário, como está no $\S 1^{\circ}$ do art. $4^{\circ}$ do Anteprojeto de Lei, dispor sobre a função social do contrato (art. $421 \mathrm{CC}$ ) e sobre os princípios de probidade e boa-fé (art. $422 \mathrm{CC}$ ). O $\S 2^{\circ}$ do art. $4^{\circ}$ do Anteprojeto de Lei dispõe sobre a onerosidade excessiva ou a teoria da imprevisão, também disciplinada na parte geral dos contratos do Código Civil (art. 478). Além disso, o $\S 3^{\circ}$ do art. $4^{\circ}$ do Anteprojeto de Lei trata da lesão, defeito do negócio jurídico disciplinado no art. 157 do Código Civil, bem como o $\S 4^{\circ}$ do mesmo artigo dispõe sobre os contratos de adesão, como o art. 423 do Código Civil. Logo, uma lei, pela matéria que disciplina, não pode ter disposições alheias ou mais genéricas que o seu objeto.

A definição de reprodução foi mantida do inciso VI do art. $5^{\circ}$ da Lei n. 9.610/1998.

No entanto, o inciso VII do art. $5^{\circ}$ sofreu acréscimo proposto pelo Ministério da Cultura: “[...], ressalvados os casos que a Lei dispensa autorização". ${ }^{122}$ Após a consulta pública, a redação do inciso definidor de contrafação permaneceu a mesma da Lei $n$. 9.610/1998. Os casos dispensados pela lei, como as limitações aos direitos autorais, não precisam ser enfatizados em complemento de inciso definidor, pois constam de parte específica da lei.

A definição de obra audiovisual na alínea "i” do inciso VIII do art. $5^{\circ}$ melhorou, pois foi excluído o vocábulo "reprodução". ${ }^{123}$

\footnotetext{
${ }^{122}$ BRASIL. Ministério da Cultura. Anteprojeto de Lei de Modernização da Lei Autoral. Op. cit.

123 “Art. 5'. [...] i) audiovisual - a obra que resulta de imagens com ou sem som, que tenha finalidade de criar, a impressão de movimento, independentemente dos processos de sua captação, do suporte usado inicial ou posteriormente para fixá-lo, bem como dos meios utilizados para sua veiculação;" (BRASIL. Ministério da Cultura. Anteprojeto de Lei de Modernização da Lei Autoral. Op. cit.).
} 
Ao art. 17 na redação do Anteprojeto de Lei foi acrescido o $\S 4^{\circ}$, que disciplina utilização separada de contribuição individual em obra coletiva, conquanto não prejudique a exploração desta.

O Anteprojeto, no que atine ao exercício dos direitos morais de autor post mortem, no $\S 1^{\circ}$ do art. 24 acrescentou o direito de ter acesso ao único e raro exemplar da obra em poder outrem, sem prejudicar os direitos deste.

A disciplina da cópia privada, dentro das limitações do direito de autor, foi pormenorizada nos incisos I e II do art. 46 do Anteprojeto. ${ }^{124}$

O inciso I, a nosso ver, melhorou em parte a disciplina da cópia privada, restrita apenas a pequenos trechos na lei vigente. Contudo, a redação do inciso I diz que a obra deve ser legitimamente adquirida. Cremos que a subordinação da cópia privada à aquisição legítima da obra original restringe demasiadamente o direito de alguém efetuar uma cópia para uso privado e não comercial. Em muitos casos de cópia para uso privado, o usuário se vale desse meio pela indisponibilidade da obra no mercado, v.g., o caso de livros cuja edição está esgotada há muitos anos.

Por outro lado, o inciso II do art. 46 inseriu disposição importante sobre a conversão de suportes. Neste caso, é mister dispor sobre a aquisição legítima da obra de modo a frisar que a cópia é oriunda de suporte diverso, v.g., converter um fonograma gravado em compact disc para outro formato digital, como o MP3. A conversão tem o fito de permitir a percepção sensitiva pelo usuário em meio diverso do original, sem frustrar os direitos do autor sobre a obra.

Ainda o mesmo art. 46, no inciso XII, frisa e acrescenta que, mesmo sem intuito de lucro, as palestras, as conferências e aulas não podem ser divulgadas por aqueles que foram os destinatários, sem prévia autorização expressa do ministrante. É importante destacar

\footnotetext{
124 “Art. 46 [...] I - a reprodução, por qualquer meio ou processo, em uma só cópia e por pessoa natural, para seu uso privado e não comercial, de obra legitimamente obtida, exceto por meio de locação, desde que feita a partir de exemplar de obra publicada legalmente; II - a reprodução, por qualquer meio ou processo, em uma só cópia para cada suporte e por pessoa natural, para seu uso privado e não comercial, de obra legitimamente obtida, exceto por meio de locação ou se o acesso à obra foi autorizado por um período de tempo limitado, desde que feita a partir de original ou cópia de obra publicada legalmente, para o fim específico de garantir a sua portabilidade ou interoperabilidade;" (BRASIL. Ministério da Cultura. Anteprojeto de Lei de Modernização da Lei Autoral. Op. cit.).
} 
que, com novos instrumentos tecnológicos de baixo custo, é possível captar o som ou som e imagem sem grandes empecilhos. O diminuto tamanho desses aparelhos também permite o registro, quase sempre, sem nenhuma percepção do ministrante. Vale lembrar que por meio da rede mundial de computadores - Internet - é possível divulgar em segundos uma conferência ou aula para usuários dispersos pelos quatro cantos do planeta. Por isso, é mister a autorização prévia do ministrante, pois o risco de violação ao direito à integridade mediante alterações, algumas vezes vexatórias, é muito grande.

Por seu turno, a obra sob encomenda ou decorrente de vínculo recebeu disciplina mais detalhada no Anteprojeto, no art. 52A. Sublinhamos o $\S 9^{\circ}$ do art. 52A, dispondo que os direitos morais de autor são protegidos de cláusulas contratuais que os limitem. Como vimos no capítulo primeiro deste trabalho, em especial o item dedicado ao Código Civil de 1916, o art. 667 - a cessão de paternidade - tornava lícita a antiga prática editorial do "ghost-writer" ou "nègre", prática que ainda perdura em nossos dias. Sabemos que há muitos profissionais engajados na atividade editorial, mas é lícito e justo atribuir a cada um a sua participação na obra. Antes de tudo, trata-se de proteger a fé pública.

O Anteprojeto também disciplina a licença não voluntária. Lembramos que o Código Civil de 1916, no art. 660, sob a denominação de "desapropriação por utilidade pública", tratou do mesmo instituto. A Lei n. 5.988/1973, dentre as atribuições do Conselho Nacional de Direito Autoral, no inciso VIII do art. 117, diz que cabe ao Conselho manifestar-se sobre pedidos de licença não voluntária disciplinada em tratados e convenções internacionais. A lei vigente não trata da matéria.

Enfim, como nas leis anteriores, o Anteprojeto, mesmo depois da consulta pública, não dispôs sobre o plágio em qualquer espécie de obra protegida. Cremos que andou bem o Anteprojeto, dentre muitas alterações propostas, posto que, como veremos adiante, o plágio não é de fácil identificação, bem como sua ocorrência é uma questão de gênese criativa.

\subsubsection{Projeto de Lei n. 232, de 2012: reforma do Código Penal brasileiro}

O Projeto de Lei n. 232, de 2012 - Projeto de Reforma do Código Penal Brasileiro —, foi elaborado por Comissão de Juristas criada pelo Requerimento n. 756, de 2011, do 
Senador Pedro Taques, aditado pelo Requerimento de n. 1.034, do Senador José Sarney, Presidente do Senado, tendo sido aprovada pelo Senado em 10 de agosto de 2011. A Comissão foi presidida pelo Ministro Gilson Langaro Dipp, do Superior Tribunal de Justiça. $^{125}$

A Comissão de Juristas, conforme Luiz Carlos dos Santos Gonçalves, Relator Geral, ficou incumbida de:

\begin{abstract}
a) modernizar o Código Penal; b) unificar a legislação penal esparsa; c) estudar a compatibilidade dos tipos penais hoje existentes com a Constituição de 1988, descriminalizando condutas e, se necessário, prevendo novas figuras típicas; d) tornar proporcionais as penas dos diversos crimes, a partir de sua gravidade relativa; e) buscar formas alternativas, não prisionais, de sanção penal. ${ }^{126}$
\end{abstract}

O Anteprojeto de Reforma do Código Penal Brasileiro segue a mesma linha mestra adotada no Código Penal vigente: uma Parte Geral e uma Parte Especial para os crimes em espécie. Devido ao aumento de leis penais esparsas, principalmente em leis que disciplinam também outras matérias, o Relator Geral diz que o Plano de Trabalho da Comissão de Juristas teve em vista atrair para o sistema do Código Penal as normas penais esparsas, de modo a transformar o Código Penal em centro do ordenamento jurídicopenal. $^{127}$

Marco Antonio Marques da Silva ficou encarregado do Título III - Dos Crimes Contra a Propriedade Imaterial - da Parte Especial do Anteprojeto. A ubicação da matéria autoral continua em título de mesmo número da lei vigente.

Na exposição de motivos das propostas de alteração do título dedicado à matéria, Marco Antonio Marques da Silva seguiu uma vereda inversa à do art. 184 do Código Penal de 1940. O art. 184 do Código Penal, desde a publicação desse diploma, como visto retro, sempre foi uma norma penal em branco. No Anteprojeto, preferiu-se tipificar na norma penal a violação de direito autoral, no caput do art. 172:

\footnotetext{
${ }^{125}$ BRASIL. Senado Federal. Relatório Final da Comissão de Juristas para a Elaboração de Anteprojeto de Código Penal: Projeto de Lei n. 236, de 2012. 480 fls. Disponível em: <http://www12.senado.gov.br/noticias/Arquivos/2012/06/pdf-veja-aqui-o-anteprojeto-da-comissao-especialde-juristas>. Acesso em: 02 ago. 2012.

126 Ibidem, p. 3.

127 Ibidem, p. 7.
} 
Art. 172. Violar direito autoral por meio da reprodução ou publicação, por qualquer meio, com intuito de lucro direto ou indireto, de obra intelectual, ou de fonograma ou videograma, no todo ou em parte, sem autorização expressa do autor, produtor ou de quem os represente.

Pena - prisão, de seis meses a dois anos. ${ }^{128}$

Pensamos que o redator do art. 172 restringiu consideravelmente o tipo penal constante no caput, não deixando à lei específica sobre direitos autorais estabelecer quais são as violações de direito autoral, como foi feito na sequência das alterações sofridas pelo art. 184 do Código Penal. Entretanto, na exposição de motivos, Marco Antonio Marques da Silva diz que: "As sugestões apresentadas, especialmente a supressão do tipo penal aberto (artigo 184, caput, do Código Penal de 1940), têm o fim de evitar a aplicação do Direito Penal como primeira opção de tutela do direito do autor". ${ }^{129}$ Ora, cremos que a redação do caput impede a aplicação da lei penal para certas violações, v.g., a usurpação de nome ou pseudônimo, que era tipificado no art. 185 do Código Penal, revogado pela Lei n. $10.695 / 2003 .{ }^{130}$

Além disso, não podemos olvidar que o Direito não segue no mesmo passo da tecnologia, sobretudo numa época na qual a cada dia surgem novas formas tecnológicas mais eficientes. Por isso, a redação do caput do art. 184 do Código Penal vigente permite maior abrangência dos fatos violadores de direito autoral, não impedindo a aplicação da norma penal existente para novas formas de violação, não conhecidas ou não pensadas, no momento da elaboração do tipo penal.

Cremos que certas violações de direito autoral, particularmente aquelas de cunho mais patrimonial que moral, devam ser objeto de tipificação penal. Não pretendemos dizer que as ofensas aos direitos de personalidade não devam ser tipificadas e sancionadas por normas penais, como ocorre nos crimes contra a honra. Cremos que, em certos casos, a pena de prisão não surte o mesmo resultado punitivo a impedir a reiteração da conduta. No entanto, de acordo com o Relator Geral do Projeto de Lei n. 236/2012, a Comissão ficou incumbida de buscar penas alternativas à pena de prisão, o que não está presente nas penas

\footnotetext{
${ }^{128}$ BRASIL. Senado Federal. Relatório Final da Comissão de Juristas para a Elaboração de Anteprojeto de Código Penal. Op. cit., p. 318.

${ }^{129}$ Ibidem, p. 315.

${ }^{130}$ A nosso ver, o redator do caput do art. 172, do Projeto de Lei n. 236/2012, fundiu, mas adaptando, o caput do art. 184 do Código Penal vigente com seu $\S 1^{\circ}$, ambos com redação dada pela Lei n. 10.695/2003.
} 
do caput e dos parágrafos do art. 172. Nos casos de usurpação de nome ou pseudônimo alheio ou de plágio, obter-se-ia resultado punitivo melhor com a veiculação nos meios de comunicação de decisão judicial condenatória transitada em julgado. A norma penal tem o fim não só de punir, mas também de educar.

Para a interpretação do caput do art. 172, cremos ser necessário verificar as definições constantes no art. $5^{\text {o }}$ da Lei n. 9.610/1998, v.g., reprodução (inciso VI), publicação (inciso I) e fonograma (inciso IX). Afirmamos isto porque as normas penais não podem dar margem a ambiguidades, corolário do princípio da legalidade, bem como o bem jurídico protegido: o direito autoral.

A alínea "i” do inciso VIII do art. 50 da Lei n. 9.610/1998 define o que é obra audiovisual, o que não foi observado na redação do $\S 1^{\circ}$ do art. 172 do Projeto de Lei $n$. 236/2012, preferindo o redator o emprego do vocábulo "videograma", de sentido mais restrito que "obra audiovisual". Dessa maneira, se houver uma violação de direito autoral de obra audiovisual diversa do "videograma”, não haverá um modo de punir. O inciso VIII do art. $6^{\circ}$ da Lei n. 5.988/1973 definia videograma: “[...] a fixação de imagem e som em suporte material". ${ }^{131}$ Por essas razões, a atual redação do caput do art. 184 do CP é melhor que a proposta do caput do art. 172 do Projeto de Lei n. 236/2012.

$\mathrm{O} \S 1^{\circ}$ do art. 172 do Projeto de Lei n. 236/2012 é que mais atrai nossa atenção dentre todas as propostas da Reforma do Código Penal Brasileiro. É o novo tipo penal denominado "plágio intelectual": "Plágio intelectual - $§ 1^{\circ}$ Nas mesmas penas incorre quem apresentar, utilizar ou reivindicar publicamente, como própria, obra ou trabalho intelectual de outrem". ${ }^{132}$

Vimos no capítulo primeiro que o plágio, de furto de pessoas livres ou escravos passou a designar o furto de obra intelectual. Isto se deve graças ao episódio ocorrido entre o poeta latino Marcial e Fidêncio, bem como na usurpação do hemistíquio de Vitrúvio por Batilo, imortalizado nos versos: "Sic vos, non vobis". Hoje, o vocábulo "plágio" tem o sentido comum de subtração de obra intelectual alheia ou elementos desta com usurpação

\footnotetext{
${ }^{131}$ BRASIL. Lei n. 5.988, de 14 de dezembro de 1973. Op. cit.

${ }^{132}$ BRASIL. Senado Federal. Relatório Final da Comissão de Juristas para a Elaboração de Anteprojeto de Código Penal. Op. cit., p. 31.
} 
de paternidade. Logo, é um substantivo que não necessita de um adjetivo para ser bem individualizado e compreendido, pois ninguém se refere ao plágio como subtração de pessoas sob nosso poder.

Vale aqui mencionar a lição de Paula Baptista ao dizer que a letra da lei não admite superfluidades. ${ }^{133} \mathrm{O}$ adjetivo "intelectual” não tem nenhum fim de identificação ou qualificação em relação ao substantivo "plágio", sendo totalmente desnecessário para a compreensão do fenômeno tipificado. Trata-se de redundância, posto que o plágio pressupõe apropriação injusta ou subtração de elementos criativos de qualquer obra.

Outra questão suscitada da leitura do $\S 1^{\circ}$ do art. 172 do Projeto de Lei n. 236/2012 é o conceito de "obra". Os incisos do art. $7^{\circ}$ da Lei n. 9.610/1998, bem como os incisos do art. $6^{\circ}$ da Lei n. 5.988/1973, dispõem de modo exemplificativo quais são as obras intelectuais protegidas pelo direito autoral. O caput do art. $7^{\circ}$ complementa a disposição do caput, do art. $6^{\circ}$, ao dizer: “[...], expressas por qualquer meio ou fixadas em qualquer suporte, tangível ou intangível, conhecido ou que se invente no futuro”.

Ora, qual a razão de constar no tipo penal de plágio intelectual “[...] obra ou trabalho intelectual de outrem"? Se obra é a criação do espírito, consoante a disciplina legal autoral, o que seria trabalho intelectual diverso de obra? Não vislumbramos outra forma de trabalho intelectual passível de plágio que não seja uma obra intelectual ou uma criação do espírito. Certo que hoje se discute sobre as criações elaboradas por programas de computador, que não estão excluídas da definição legal, do caput do art. $7^{\circ}$ da Lei n. $9.610 / 1998$.

Marco Antonio Marques da Silva não justificou a razão de constar dentre as violações de direito autoral um parágrafo explícito sobre o denominado plágio intelectual. Imaginamos que tenha tentado justificar, apesar de a referência ao art. 184 ser o crime de

\footnotetext{
${ }^{133}$ Nota de rodapé 4: "Interpretatio in quacumque dispositone ne sic facienda, ut verba nos sint superflua, et sine virtute operandi (Roll. a Vall. Consil. 6161 n. 44). O Assento de 22 de outubro de 1778 consagra a regra: que no texto da lei se deve entender não haver frase, nem mesmo palavra supérflua." Tradução: "Em qualquer que seja a disposição, não deve a interpretação ser feita de tal modo que haja palavras supérfluas e sem força de produzir efeito (Roll. a Vall. consil. 6161 n. 44).”. (PAULA BAPTISTA, Francisco de. Compêndio de hermenêutica jurídica. São Paulo: Saraiva, 1984, p. 12 e nota de rodapé 4, itálicos no original).
} 
assédio sexual na redação do Anteprojeto, atual Projeto de Lei n. 236/2012. ${ }^{134}$ Diz Marco Antonio Marques da Silva que: “A fim de suprir uma lacuna legislativa, tipifica-se a conduta de apresentar obra ou trabalho de terceiros, ainda que parcialmente, como próprio ( $\$ 3^{\circ}$, do artigo 184 do Novo Código Penal)". 135

Por seu turno, o Relator Geral do Anteprojeto de Reforma do Código Penal, que se tornou o Projeto de Lei n. 236/2012, do Senado Federal, diz que a reforma tem o escopo de “criar tipos compreensivos, capazes de oferecer proteção para as diversas projeções do mesmo bem jurídico, evitando-se tipificações prolixas e repetidas". ${ }^{136}$ Ora, não é o que aparenta a redação do art. 172 em comento, sobretudo o $\S 1^{\circ}$, pois, como dissemos, o art. 184 do Código Penal vigente, com todas as alterações, é melhor, não só o caput como os parágrafos. A redação do art. 172 do Projeto de Lei n. 236/2012 tem disposições contrárias ao espírito da reforma.

Vimos até aqui que nenhuma lei autoral e lei penal brasileiras procuraram disciplinar de modo explícito e determinado o plágio, fenômeno registrado desde os tempos remotos. Na verdade, não compreendemos a razão da inserção do tipo penal do plágio intelectual entre as violações de direito autoral. De fato, a interpretação das normas penais, em regra, não admite o emprego da analogia, como na interpretação das normas civis. Então, conforme a justificativa do redator do art. 172, a introdução do tipo penal plágio intelectual é apenas para preencher uma lacuna legislativa! Da leitura da justificativa, não vemos um forte e determinante motivo para a criação de um novo tipo penal intitulado de plágio intelectual. Logo, cremos ser mais prudente e razoável um tipo penal em branco para abarcar todas as violações de direito autoral, sem determinar certas violações em detrimento de outras.

Por outro lado, temos notícia de que o plágio foi tipificado apenas nas legislações peruana e espanhola, como veremos adiante, sendo que outros países não disciplinam o plágio de forma explícita, nem em norma específica autoral nem em norma penal.

Se a intenção do autor do título dedicado à propriedade imaterial foi preencher

\footnotetext{
${ }^{134}$ BRASIL. Senado Federal. Relatório Final da Comissão de Juristas para a Elaboração de Anteprojeto de Código Penal. Op. cit., p. 85.

135 Ibidem, p. 316.

136 Ibidem, p. 5.
} 
lacunas, por que não foi incluído na reforma o tipo penal da usurpação de nome ou pseudônimo alheio, existente no Código Penal até a alteração dada pela Lei n. 10.695/2003? Todavia, na exposição de motivos do Título III da Parte Especial do Projeto de Lei n. 236/2012, afirma o autor que:

\begin{abstract}
No que diz respeito a conduta de usurpar o nome ou pseudônimo alheio, coíbe-se a falsa atribuição a alguém, mediante o uso de nome, pseudônimo ou outro sinal adotado por alguém para designar seus trabalhos, o que caracteriza uma afronte à propriedade imaterial, por desprestigiar o autor e ludibriar a própria sociedade por receber uma informação inverídica. ${ }^{137}$.
\end{abstract}

No entanto, não há um parágrafo ou trecho no Projeto de Lei n. 236/2012 que diga de forma explícita a conduta acima dita, constando o plágio intelectual, tipo penal até agora não pensado e positivado em nosso ordenamento jurídico. Com efeito, a usurpação de nome ou pseudônimo alheio é tão grave quanto o plágio, sendo ambas condutas muito semelhantes na finalidade de enganar a fé pública.

Por sua vez, o $\S 4^{\circ}$ visa a excluir das violações de direito autoral a cópia privada ao dispor: "§ $4^{\circ}$. Não há crime quando se tratar de cópia integral de obra intelectual ou fonograma ou videograma, em um só exemplar, para uso privado e exclusivo do copista, sem intuito de lucro direto ou indireto". 138

Ao abordar a Lei n. 5.988/1973, em especial o inciso II do art. 49, bem como o inciso II do art. 46 da Lei n. 9.610/1998, vimos que a cópia de um exemplar para uso privado já está disciplinada dentre as limitações aos direitos de autor, não carecendo de outra disposição, acima de tudo em lei penal. A nosso ver, as limitações aos direitos de autor devem estar em lei especial sobre a seara autoral, não competindo ao legislador disciplinar no âmbito penal.

Em seguida, o autor do título sobre os "Crimes contra a Propriedade Imaterial" do Projeto de Lei n. 236/2012 disciplina a "Alteração de obra de criação alheia": "Art. 173. Modificar ou mutilar obra de criação alheia prejudicando a reputação do autor". ${ }^{139}$

\footnotetext{
${ }^{137}$ BRASIL. Senado Federal. Relatório Final da Comissão de Juristas para a Elaboração de Anteprojeto de Código Penal. Op. cit., p. 316.

138 Ibidem, p. 319.

${ }^{139}$ Ibidem, p. 319.
} 
Aqui também não há necessidade de disposição em lei penal sobre o direito à integridade, matéria específica de direitos morais de autor, disposta no inciso IV do art. 25 da Lei n. 5.988/1973 e no inciso IV do art. 24 da Lei n. 9.610/1998. Como o $§ 4^{\circ}$ do art. 172 do Projeto de Lei n. 236/2012, não assiste razão para constar no Código Penal uma disposição específica contemplada em lei autoral.

O Relator Geral do Anteprojeto de Reforma do Código Penal diz que, a respeito da legislação penal extravagante, um dos critérios do Plano de Trabalho da Comissão foi: “[...] da criminalização da conduta apenas quando outros ramos do direito não puderem fornecer resposta suficiente". ${ }^{140}$ Aqui também não aparenta ser o caminho trilhado pelo autor dos arts. 172 e 173 do Anteprojeto de Reforma do Código Penal. As leis específicas, tanto a Lei n. 5.988/1973 como a Lei n. 9.610/1998, fornecem subsídios suficientes de maneira a não deixar dúvidas para que outra lei trate da mesma matéria.

Vemos que, como ocorreu no Código Penal de 1890, o legislador penal pretende disciplinar em detalhes as violações do direito autoral. Contudo, cabe lembrar que o Código Penal de 1890 é anterior à primeira lei brasileira a dispor detalhadamente sobre os direitos autorais - a Lei n. 496, de $1^{\circ}$ de agosto de 1898 - motivo pelo qual houve o tratamento das violações de direito autoral em norma penal.

Por outro lado, como vimos no capítulo primeiro deste trabalho, o Código Penal de 1890 sofreu críticas no que tange à redação, considerada inferior ao Código Criminal do Império. A experiência jurídica pátria mostra que um código, por ser unicamente posterior, não traz melhorias na disciplina de um ramo jurídico, acima de tudo em matéria penal, onde o cuidado deve ser maior por estabelecer regras que sancionam penas restritivas de liberdade e de direitos.

Enfim, esperamos que durante o trâmite legislativo do Projeto de Lei n. 236, de 2012, do Senado Federal, as comissões especializadas das duas Casas do Congresso Nacional possam analisar bem as incongruências e conflitos desse Projeto de Lei com as outras normas de nosso ordenamento jurídico, além de possíveis vetos presidenciais.

\footnotetext{
${ }^{140}$ BRASIL. Senado Federal. Relatório Final da Comissão de Juristas para a Elaboração de Anteprojeto de Código Penal. Op. cit., p. 06.
} 
Reiteramos que o art. 184 do Código Penal vigente nos parece melhor na proteção penal dos direitos autorais por ser uma norma penal em branco. 


\section{DIREITO INTERNACIONAL E DIREITO COMPARADO}

\subsection{Tratados internacionais de Direito de Autor}

\subsubsection{Convenção de Berna}

A Convenção de Berna, de 9 de setembro de 1886, foi completada em Paris em 4 de maio de 1896, revista em Berlim em 13 de novembro de 1908, completada em Berna em 20 de março de 1914, revista em Roma em 2 de junho de 1928, em Bruxelas em 26 de junho de 1948, em Estocolmo em 14 de julho de 1967 e em Paris em 24 de julho de 1971. A Convenção de Berna passou a ser vigente em nosso ordenamento jurídico em 20 de abril de 1975 , pelo Decreto n. 75.699 de 6 de maio de $1975 .^{141}$

Como vimos no capítulo primeiro, a Convenção de Berna é o instrumento padrão no âmbito internacional para a proteção das obras literárias, artísticas e científicas.

A Convenção de Berna não define quem é o autor, como a Lei n. 9.610/1998 (art. 11). Por seu turno, a Convenção de Berna, no art. 15, diz que se pressupõe autor quem indica o nome ou pseudônimo na obra. Segundo Delia Lipszyc, a presunção é iuris tantum, admitindo prova em contrário. ${ }^{142}$

$\mathrm{O}$ art. $2^{\circ}$ da Convenção de Berna enumera, como o art. $7^{\circ}$ da Lei n. 9.610/1998, as obras protegidas. Frisa-se que a lista de obras constantes no art. $2^{\circ}$ da Convenção de Berna é exemplificativa, não limitando, também como na lei autoral brasileira, a proteção de obras futuras fixadas em novos suportes. ${ }^{143}$ No entanto, a Lei n. 9.610/1998 define no caput do art. $7^{\circ}$ que as obras intelectuais protegidas são as criações do espírito.

O princípio da proteção mínima consta no $\S 1^{\circ}$ do art. $5^{\circ}$ da Convenção de Berna. Tal princípio determina um padrão convencional mínimo de proteção no caso de a

\footnotetext{
${ }^{141}$ BRASIL. Coletânea de Legislação de Comunicação Social. Op. cit., p. 127-141.

${ }^{142}$ LIPSZYC, Delia. Op. cit., p. 126.

${ }^{143}$ Cf. LUCAS, André; LUCAS, Henri-Jacques. Op. cit., p. 923.
} 
legislação de um país unionista não proteger suficientemente uma obra. Neste caso, de acordo com Delia Lipszyc, a Convenção completa as disposições da legislação nacional. ${ }^{144}$

Princípio muito importante na proteção da obra é o princípio da proteção automática, independente de formalidades, como dispõe o $\S 2^{\circ}$ do art. $5^{\circ}$ da Convenção de Berna. A proteção de qualquer obra tutelável não requer seja registrada ou, em outros termos, a outorga da proteção independe de procedimentos administrativos. Por seu turno, os Estados Unidos sempre relutaram na adesão a esse princípio, uma vez que a proteção no sistema estadunidense de copyright dependia de formalidades. Mas, mesmo depois da adesão dos Estados Unidos à Convenção de Berna, Delia Lipszyc diz que ainda há estímulo ao registro, sendo uma condição para o exercício de direito em juízo. ${ }^{145}$

Não existe uma definição de cada um dos direitos patrimoniais de autor na Convenção de Berna. Somente no $\S 3^{\circ}$ do art. $3^{\circ}$ há uma definição de obra publicada. Os outros artigos enfatizam o caráter de exclusividade do autor na exploração econômica da obra.

Por sua vez, o art. 6 bis da Convenção de Berna incorporou os direitos morais de autor. A inserção dos direitos morais de autor na Convenção de Berna foi realizada na revisão de Roma de 1928. Delia Lipszyc nos conta que algumas legislações nacionais e a jurisprudência os tinham recepcionado. A proposta de inserção dos direitos morais de autor na Convenção partiu das delegações da Itália, da França, da Bélgica, da Tchecoslováquia e da Romênia. Destaca-se que o jurista italiano Eduardo Piola Caselli foi um dos fervorosos defensores da introdução dos direitos morais de autor na Convenção. ${ }^{146}$

Contudo, não são todos os direitos morais de autor positivados expressamente no art. 6 bis da Convenção de Berna, mas apenas o direito de reivindicar a paternidade da obra e o direito de manter a integridade da obra, condicionados estes direitos à ofensa da honra e da reputação do autor ofendido. Não há disposição expressa no art. 6 bis ou em outro artigo da Convenção sobre o direito de inédito. Henri Desbois destaca que não são em todos os casos que as alterações na obra ou usurpação de paternidade, como ocorre no

\footnotetext{
${ }^{144}$ LIPSZYC, Delia. Op. cit., p. 680.

${ }^{145}$ Ibidem, p. 536-537.

${ }^{146}$ Ibidem, p. 641-642.
} 
plágio, ofendem a honra e a reputação do autor. ${ }^{147}$ Cremos que a inserção, mesmo que subordinada a ofensa à honra ou à reputação do autor na Convenção de Berna, é melhor que nenhuma disposição expressa sobre os direitos morais de autor, os primeiros direitos diretamente atingidos no ato violador do plágio.

Ressalta-se que até a inserção do art. 6 bis na Convenção de Berna, em linhas gerais, a Convenção tinha um caráter exclusivamente patrimonial, visando à proteção dos autores e de suas obras na circulação econômica internacional. Não negamos que os direitos patrimoniais de autor são ofendidos no ato violador do plágio, frustrando os interesses do autor e, no caso do contrato de edição, também do editor. Mas, inicialmente, o plágio lesa, no momento da criação intelectual, os direitos morais de autor na usurpação de paternidade e na extração maliciosa de elementos da obra protegida.

Cabe ainda dizer em relação à tutela pessoal do autor nos Estados Unidos que não há, nesse país, como há nos países de tradição jurídica romano-germânica, um sistema de direitos da personalidade ou de direitos morais de autor, sendo tutelados indiretamente pelos tribunais, buscando as soluções no Common Law por meio da privacy. ${ }^{148}$

$\mathrm{O}$ art. $7^{\circ}$ da Convenção de Berna estabelece o período mínimo de proteção das obras protegidas. Conforme o caput desse artigo, a duração compreende toda a vida do autor e cinquenta anos após a sua morte. $\mathrm{O} \S 6^{\circ}$ do art. $7^{\circ}$ diz que os países unionistas podem aumentar o prazo de proteção post mortem por período superior aos prazos da Convenção de Berna. No Brasil, consoante o art. 41 da Lei n. 9.610/1998, o prazo de duração da proteção post mortem do autor é de setenta anos.

A Convenção de Berna, ao tratar das violações de direito de autor no $\S 1^{\circ}$, art. 15 , determina que são presumidos autores aqueles indicados de maneira usual nas obras. A presunção estabelecida pela Convenção de Berna é juris tantum, admitindo prova em contrário. ${ }^{149} \mathrm{Na}$ ocorrência de plágio, o direito de paternidade é o primeiro direito violado. Se não houvesse presunção relativa de autoria da obra, seria muito difícil pleitear reparação em juízo, posto que o usurpador, a princípio, é considerado o autor da obra. Mais difícil

\footnotetext{
${ }^{147}$ DEBOIS, Henri. Op. cit., p. 890-891.

${ }^{148}$ Cf. LIPSZYC, Delia. Op. cit., p. 46.

${ }^{149}$ Cf. Ibidem, p. 674.
} 
ainda seria no caso de usurpação de paternidade de obra inédita, não olvidando que o autor não é obrigado a dar conhecimento ao público de suas criações intelectuais.

Na sequência, o art. $\S 1^{\circ}$ do art. 16 diz que: "Toda obra contrafeita pode ser apreendida nos países da União onde a obra original tem direito à proteção legal" ${ }^{150} \mathrm{O}$ texto convencional não define a contrafação, como faz a Lei n. 9.610/1998 no inciso VII do art. $5^{\circ}$. O sentido do vocábulo "contrafação" no texto convencional, a nosso ver, é genérico, isto é, a contrafação é termo de sentido amplo que designa qualquer espécie de violação autoral.

Por conseguinte, a Convenção de Berna não fala em nenhum trecho sobre o plágio, em qualquer espécie de obra. Como visto no capítulo anterior, exceto o Projeto de Lei n. 232, de 2012 , no $\S 1^{\circ}$ do art. 172 , nenhuma lei brasileira definiu o plágio. No âmbito da Convenção de Berna, o espírito do estatuto internacional é estabelecer um padrão mínimo de proteção, cabendo aos países membros da União legislarem pormenorizadamente sobre os direitos de autor.

\subsubsection{Convenção Universal sobre o Direito de Autor}

A Convenção Universal sobre o Direito de Autor, aprovada em Genebra em 1952, revista em Paris em 1971, passou a ser vigente no ordenamento jurídico brasileiro pelo Decreto 76.905/1975, ${ }^{151}$ em 11 de setembro de 1975.

O adjetivo "universal” refere-se ao caráter abrangente da Convenção. A Convenção de Berna era considerada muito europeia por ter como referência o sistema de Droit d'Auteur, não incluindo o sistema de copyright, buscando harmonizar a proteção das obras no âmbito internacional. ${ }^{152}$

Um problema enfrentado inicialmente pela Convenção Universal no âmbito internacional da proteção do direito de autor foi o possível esvaziamento da Convenção de Berna pelos países membros. De acordo com Delia Lipszyc, a intenção dos países

\footnotetext{
${ }^{150}$ BRASIL. Coletânea de Legislação de Comunicação Social. Op. cit., p. 131.

${ }^{151}$ Ibidem, p. 141-149.

${ }^{152}$ Cf. ASCENSÃO, José de Oliveira. Op. cit., p. 641.
} 
participantes da elaboração desta convenção não era revogar a Convenção de Berna, mas criar uma "convenção ponte". ${ }^{153}$ Tal intento está expressamente disposto no art. 19 da Convenção Universal.

Os direitos morais de autor não são mencionados de modo expresso pela Convenção Universal, como consta no art. 6 bis da Convenção de Berna. No entanto, de maneira implícita, o direito moral de autor está presente na alínea "e" do art. 5o, que determina a menção do título e do nome da obra original em todos exemplares de obras traduzidas.

O motivo da regulamentação mais detalhada das traduções, único direito garantido e de exclusividade do autor, diversamente da Convenção de Berna, que estabelece direitos fundamentais e exclusivos, conforme Delia Lipszyc, deve-se ao aumento de traduções para circulação e difusão das obras. ${ }^{154}$

A tradução, obra derivada, pode ser uma obra plagiadora, em situações de usurpação de paternidade pelo tradutor ou, no ato de traduzir, no caso de ofender a integridade da obra original ao conter inserções não autorizadas ou distorcer ideias e opiniões do autor. Porém, a Convenção Universal, ao enfatizar o aspecto econômico nas licenças obrigatórias não exclusivas de tradução, não acolheu os direitos morais envolvidos na derivação da obra original. Poderia, pensamos, estabelecer certas regras de comunicação entre o autor vivo titular de diretos sobre obra originária e o tradutor, v.g., troca de correspondências e soluções de conflitos entre ambos no escopo de não violar o direito de integridade.

No fito de harmonizar os sistemas no que atine às formalidades para a proteção das obras, a Convenção Universal introduziu a aposição da letra "c" dentro de uma circunferência (C) desde a primeira publicação da obra, para dispensar de formalidades como registro e depósito, de acordo com o $\S 1^{\circ}$ do art. $3^{\circ}$.

A duração da proteção é de no mínimo vinte e cinco anos após a morte do autor, ressalvado ao Estado Contratante que, antes da vigência da Convenção Universal, tenha

\footnotetext{
${ }^{153}$ LIPSZYC, Delia. Op. cit., p. 751-752.

${ }^{154}$ Ibidem, p. 763-764.
} 
restringido o prazo em seu território, a faculdade de determinar prazos protetivos a partir da publicação da obra. Ainda, conforme nos relata Delia Lipszyc, os Estados Unidos desconheciam um sistema de duração de prazos de proteção considerando o período da vida do autor. ${ }^{155}$

Portanto, como na Convenção de Berna, a Convenção Universal em nenhum momento se refere ao plágio, tanto de modo implícito ou explícito, se atendo mais ao aspecto econômico das licenças obrigatórias para tradução, como dispõe o art. $5^{\circ}$.

\subsubsection{Acordo sobre Aspectos dos Direitos de Propriedade Intelectual Relacionados ao Comércio (AADPIC ou TRIPS)}

O Acordo sobre Aspectos dos Direitos de Propriedade Intelectual relacionados ao comércio - mais conhecido pela sigla em inglês TRIPS (Trade-Related Aspects of Intellectual Property Rights), é o Anexo 1C do Acordo Constitutivo da Organização Mundial do Comércio - OMC, concluído em Marraqueche, em 15 de abril de 1994, e vigente no ordenamento jurídico brasileiro, em $1^{\circ}$ de janeiro de 1995, pelo Decreto $n$. 1.355 , de 30 de setembro de $1994 .{ }^{156}$

Já em seu preâmbulo, o AADPIC diz que os Estados-membros reconhecem a necessidade de padrões e princípios mais eficazes para a proteção dos direitos da propriedade intelectual relacionados ao comércio, bem como a necessidade de normas multilaterais sobre o comércio de bens contrafeitos. Também reconhecem que os direitos da propriedade intelectual são direitos privados.

O preâmbulo do AADPIC demonstra que o espírito do Acordo se insere no âmbito do comércio internacional. Não podemos esquecer que o germe da OMC foi o Acordo Geral sobre Tarifas e Comércio (GATT), remontando ao ano de 1947, ainda no contexto mundial do fim da Segunda Guerra, tendo sido concluída em 1994, já no ambiente mundial de Globalização.

\footnotetext{
${ }^{155}$ LIPSZYC, Delia. Op. cit., p. 761.

${ }^{156}$ BRASIL. Decreto n. 1.355, de 30 de setembro de 1994. Disponível em: <http://www.planalto.gov.br/ ccivil_03/decreto/1990-1994/anexo/and1355-94.pdf>. Acesso em 17 ago. 2012. Promulga a Ata Final que Incorpora aos Resultados da Rodada Uruguai de Negociações Comerciais Multilaterais do GATT.
} 
$\mathrm{O} \S 2^{\circ}$ do art. $2^{\circ}$ dispõe que são aplicáveis, no âmbito do AADPIC, a Convenção de Paris, a Convenção de Berna, a Convenção de Roma e o Tratado sobre a Propriedade Intelectual em Matéria de Circuitos Integrados. Assim, na seara autoral, os instrumentos padrões internacionais continuam a ser a Convenção de Berna sobre Direito de Autor e a Convenção de Roma para a Proteção aos Artistas Intérpretes ou Executantes, aos Produtores de Fonogramas e aos Organismos de Radiodifusão.

De maneira diversa, o AADIPC não recepcionou expressamente o art. 6 bis da Convenção de Berna, artigo relativo aos direitos morais de autor, como consta no $\S 1^{\circ}$ do art. $9^{\circ}$ :

Os Membros cumprirão o disposto nos Artigos 1 a 21 e no Apêndice da Convenção de Berna (1971). Não obstante, os Membros não terão direitos nem obrigações, neste Acordo, com relação aos direitos conferidos pelo Artigo 6 bis da citada Convenção, ou com relação aos direitos dela derivados. ${ }^{157}$

Está bem claro que a finalidade do AADIPC é disciplinar a circulação e distribuição de obras sob a ótica exclusivamente econômica, não somente pela ubiquação em um acordo internacional multilateral comercial, mas também por disposição expressa.

Vimos acima, ainda neste capítulo, que a Convenção de Berna, conquanto não tenha tratado dos direitos morais de autor até a revisão de Roma de 1928, teve o fito de estabelecer proteção aos autores e suas obras, isto é, direitos básicos no âmbito internacional, mas sob um viés em certa medida também econômico. Tal aspecto econômico, a nosso ver, reforça-se com a Convenção Universal, enfatizando a disciplina das licenças obrigatórias para traduções das obras, não dispondo de modo explícito sobre os direitos morais de autor.

Vittorio Maria De Sanctis, ao comentar a proteção convencional dos direitos morais de autor, afirma que a não recepção do art. 6 bis no AADPIC foi uma posição firme da delegação estadunidense no não reconhecimento dos direitos morais de autor. ${ }^{158}$

Os bens contrafeitos, de acordo com o Preâmbulo do AADPIC, são mais cópias

\footnotetext{
${ }^{157}$ BRASIL. Decreto n. 1.355, de 30 de setembro de 1994. Op. cit.

${ }^{158}$ DE SANCTIS, Vittorio Maria. I soggetti del Diritto d'Autore. Op. cit., p. 381.
} 
servis de obras em muitos exemplares ou outros tipos de suporte, não abrangendo as violações de direito moral de autor, primeiras a ofender a criação estética no momento de sua gênese. Nessa trilha, a tônica do AADPIC é a violação aos direitos patrimoniais de autor, posto o grande fluxo de circulação e distribuição de obras não autorizadas por seus titulares, mais conhecidas por cópias "piratas".

Portanto, não é muito surpreendente que o AADPIC, devido ao posicionamento da delegação estadunidense em relação aos direitos morais constantes na Convenção de Berna, não tenha recepcionado o art. 6 bis da Convenção de Berna. Uma vítima de plágio, por envolver mais direitos morais que patrimoniais, a princípio, procurará a reparação em seu próprio país ou no país no qual é domiciliado ao invés de na OMC.

\subsection{O plágio legislado}

O estudo legislativo que efetuamos até aqui nos mostra que o plágio não foi objeto de uma definição legal como a contrafação.

A contrafação, na legislação brasileira, teve um sentido genérico de violação autoral (art. 19 da Lei n. 496/1898), bem como na lei penal (parágrafo único, do art. 350 do Código Penal de 1890) teve a definição vinculada a violações específicas. Nas leis autorais posteriores ao Código Civil de 1916, a contrafação foi definida como reprodução não autorizada (inciso $\mathrm{V}$ do art. $4^{\circ}$ da Lei n. 5.988/1973 e inciso VII do art. $5^{\circ}$ da Lei $n$. 9.610/1998).

Nas Convenções de Berna, Universal e AADPIC não há uma definição de contrafação, menos ainda de plágio. No entanto, dois países, Peru e Espanha, positivaram o plágio em sua legislação, como veremos agora. ${ }^{159}$

\subsubsection{Peru}

A lei autoral peruana definia o plágio como uma violação autoral, na Ley n. 13.714,

${ }^{159}$ Cf. LIPSZYC, Delia. Op. cit., p. 567-568. Cf. também CHAVES, Antônio. Plágio. In: Revista de Informação Legislativa. Brasília: Senado Federal, v. 20, n. 77. p. 403-424, jan./mar. 1983. Disponível em: <http://www2.senado.gov.br/bdsf/item/id/181420>. Acesso em: 6 jul. 2011. 
de $1^{\circ}$ de setembro de $1961,{ }^{160}$ derrogada expressamente pela Ley n. 29.477 , de 17 de dezembro de 2009, ${ }^{161}$ como segue abaixo:

Art. 124. También infringe la Ley quién comete el delito de plagio, que consiste en difundir como propia en todo o en parte, una obra ajena, sea textualmente o tratando de disimular la apropiación mediante ciertas alteraciones.

Tratando-se de obras científicas, no se considera plagio la reproducción, aun literal, de exposiciones sistemáticas y desarrollos contenidos en obras análogas ajenas; pero a condición de citar la obra utilizada y su autor.

A definição de plágio compreende três pontos essenciais da violação: a usurpação de paternidade, a quantidade de elementos extraídos da obra original e a má-fé na dissimulação. Não é uma definição ruim de plágio. Todavia, não cremos ser de boa técnica legislativa incluir na definição de plágio a limitação de direito de autor de citação de obra alheia.

$\mathrm{O} \S 1^{\circ}$ do art. 172 do Projeto de Lei n. 236/2012, do Senado Federal brasileiro, não define o "plágio intelectual" como a lei revogada peruana, demonstrando mais o aspecto da comunicação ao público e da usurpação de paternidade, não dispondo sobre o ato de apropriação de elementos da obra alheia nem sobre a dissimulação. Aliás, a dissimulação deveria constar no tipo penal, pois evidencia o caráter doloso do plagiador.

Entretanto, a lei autoral peruana vigente, o Decreto Legislativo n. 822, não define o plágio como a lei revogada. ${ }^{162}$ Por sua vez, a lei autoral peruana enumera, no art. $2^{\circ}$, algumas definições de modo semelhante à Lei n. 9.610/1998. Destacamos, dentre as definições do art. $2^{\circ}$, a definição de autor como pessoa natural realizadora de criação intelectual (inciso I) e a de obra literária (inciso 23) como “Toda creación intelectual, sea de carácter literario, científico, técnico o meramente práctico, expresada mediante un lenguaje determinado".

160 PERU. Ley n. 13.714: Ley de Derechos de Autor. Disponível em: <http://www.congreso.gob.pe/ntley/Imagenes/Leyes/13714.pdf>. Acesso em: 17 ago. 2012.

161 PERU. Ley n. 29.477/2009: Consolidación del Espectro Normativo Peruano. Disponível em: <http://www.congreso.gob.pe/ntley/Imagenes/Leyes/29477.pdf>. Acesso em: 17 ago. 2012. Trata-se de lei derrogadora, que enumera no art. $1^{\circ}$ as normas que passam a não ter mais vigência no ordenamento jurídico peruano.

${ }_{162}$ PERU. Ley sobre el Derecho de Autor. Disponível em: <http://www.congreso.gob.pe/ ntley/Imagenes/DecretosLegislativos/00822.pdf>. Acesso em 17 ago. 2012. De acordo com os considerandos do Decreto Legislativo n. 822, o Poder Legislativo peruano delegou ao Poder Executivo a faculdade de legislar em matéria autoral. 
A Lei n. 9.610/1998 não define obra literária como a lei autoral peruana, mas exemplifica no rol das obras protegidas, como consta no inciso I do art. $7^{\circ}$, os textos de obras literárias, artísticas ou científicas.

Como já dissemos ao analisar a Lei n. 5.988/1973, no capítulo anterior, a máxima de Javoleno — "omnis definitio in iure civili periculosa est" —, aqui também cabe dizer que as definições legais garantem certa segurança jurídica ao intérprete, mas também podem restringir demasiadamente a aplicação da lei. Pensamos, especialmente no que se refere ao plágio, não ser a melhor via, pois o plágio deve ser examinado considerando-se as particularidades de cada caso.

\subsubsection{Espanha}

O plágio não é propriamente definido no Código Penal espanhol, mas tão somente mencionado. Não se trata de um tipo penal, sendo mais uma ação criminosa entre outras existentes no tipo bem abrangente de crime contra os direitos autorais.

Diz o art. 270 do Código Penal espanhol:

Artículo 270.

1. Será castigado con la pena de prisión de seis meses a dos años y multa de 12 a 24 meses quien, con ánimo de lucro y en perjuicio de tercero, reproduzca, plagie, distribuya o comunique públicamente, en todo o en parte, una obra literaria, artística o científica, o su transformación, interpretación o ejecución artística fijada en cualquier tipo de soporte o comunicada a través de cualquier medio, sin la autorización de los titulares de los correspondientes derechos de propiedad intelectual o de sus cesionarios. ${ }^{163}$.

Não nos parece uma boa opção legislativa a inserção do verbo "plagiar" no tipo penal acima transcrito. Nem sempre o plagiador tem o fim de lucro na sua ação delituosa. A intenção do plagiador é de prejudicar terceiro e comunicar ao público, enganando a fé pública. A conjunção “ $y$ ” nos leva a crer que o intuito de lucro, além do prejuízo de terceiro, constitua o elemento importante do tipo penal.

163 ESPANHA. Ley Orgánica 10/1995, de 23 de noviembre, del Código Penal. Disponível em: $<$ http://www.boe.es/buscar/act.php?id=BOE-A-1995-25444\&b=372\&tn=1\&p=20100623\#a270>. Acesso em 18 ago. 2012. 
Pensamos que, como o art. 184 do Código Penal brasileiro de 1940, uma norma penal em branco seria melhor que um tipo penal que trata da violação de direito autoral em detalhes. Outrossim, como já referimos, o parágrafo único do art. 350 do Código Penal brasileiro de 1890 tentou disciplinar as violações autorais sob o nome de "contrafação" em minúcias, o que pode excluir outras violações não especificadas.

Também estão presentes no art. 270 do Código Penal espanhol os direitos conexos de autor. O plágio, a princípio, ocorre no momento da extração de elementos de uma obra preexistente e da usurpação de paternidade, isto é, dá-se no momento da criação de uma obra violadora.

Melhor andou o legislador peruano ao definir o plágio, realçando os atos violadores de direito de autor. O verbo "plagiar", a nosso ver, parece uma ação no tipo penal sem conexão com os outros elementos. Vale lembrar que a letra da lei não admite superfluidades. 


\section{A IDENTIFICAÇÃO DA OBRA LITERÁRIA E REQUISITOS DE PROTEÇÃO}

\subsection{As ideias não são protegidas pelo Direito de Autor}

Os conceitos a serem expostos neste capítulo são fundamentais para a compreensão do fenômeno da criação intelectual. O plágio, ato imoral e ilícito, somente pode ser identificado por meio dos conceitos relacionados à criação intelectual. Não é possível distinguir se a identidade entre duas obras sem saber o que é o tutelado pelo Direito de Autor.

No Direito de Autor, é ponto pacífico que as ideias não são objetos tuteláveis. Contudo, para muitas pessoas não familiarizadas com a matéria, as ideias são passíveis de tutela autoral. Tal entendimento, mesmo que equivocado, enseja acusações infundadas de plágio.

As ideias, como uma abstração interior e sem elaboração, não são protegidas. Isto ocorre porque as ideias são de uso corrente. Qualquer pessoa pode captar uma ideia de outrem sem nenhuma violação autoral.

O entendimento de que as ideias não são protegidas pelo Direito de Autor tem amparo em doutrina antiga, como veremos abaixo.

Destaca Gustave Huard que as ideias gerais e fatos verdadeiros não são objeto do direito de exclusivo do autor, pois a humanidade necessita de conhecer a verdade para existir progresso. ${ }^{164} \mathrm{Na}$ mesma linha, diz Édouard Calmels que pensar é algo comum a todos os homens, não importando quem concebeu primeiro ou por último uma ideia. Tratase de um exercício do Direito Natural. A razão para tal entendimento é que a sociedade se nutre do mesmo fundo comum por meio da comunicação constante entre os homens. ${ }^{165}$

Por seu turno, Eugène Pouillet afirma que as opiniões, os métodos e os sistemas

\footnotetext{
${ }^{164}$ HUARD, Gustave. Op. cit., p. 70.

${ }^{165}$ CALMELS, Édouard. De la propriété et de la contrefaçon des oeuvres de l'intelligence. Paris: Çosse, 1856, p. 29. Disponível em: <http://gallica.bnf.fr/ark:/12148/bpt6k58585097> . Acesso em: 06 jul. 2011.
} 
concebidos pelo autor pertencem a todos. No entanto, Eugène Pouillet diz que, mesmo que as opiniões ou métodos contidos num livro não estejam no domínio privado do autor, cabe a este o direito de ser mencionado em respeito aos seus méritos. Na verdade, Eugène Pouillet quer dizer que é lícito citar trechos ou mencionar um autor, mas sempre indicando o seu nome e a obra da qual foi extraída a opinião ou sistema. ${ }^{166}$

A criação do autor surge de seus pensamentos. $O$ pensamento, sem ser exteriorizado e se revestir de uma forma, não pode ser um objeto de proteção autoral. José de Oliveira Ascenção afirma que "As criações do espírito são as ideias". ${ }^{167}$ Continua este jurista esclarecendo o iter criativo. A ideia nasce, mas é necessário um trabalho de modo a lhe dar forma. ${ }^{168}$

Le Chapelier entendia que o sistema de proteção autoral era uma exceção. O domínio público seria a regra geral. ${ }^{169}$ Seria quase impossível haver convivência entre os homens se as ideias fossem protegidas independentemente de um trabalho para se transformarem em uma obra. Também seria impossível saber de quem é a ideia, posto que a fluidez dos pensamentos não fica restrita à esfera íntima do ser humano. Ao contrário, as ideias tendem a ser propagadas no espaço e no tempo de maneira a formar a cultura dos povos.

Consequentemente, as ideias não são protegidas pelo Direito de Autor, como demonstram os autoralistas clássicos e hodiernos, por serem o ponto inicial de qualquer criação intelectual. Faz-se mister em qualquer tipo de criação intelectual o desenvolvimento com caraterísticas pessoais do criador.

\subsection{Teorias sobre a identificação da obra}

As teorias mais conhecidas pela doutrina que abordaram a identificação dos elementos tuteláveis da obra buscaram a objetividade. No entanto, pela própria natureza das criações estéticas, mais subjetivas que as criações técnicas, não é tarefa fácil precisar

\footnotetext{
${ }^{166}$ POUILLET, Eugène. Op. cit., p. 410.

${ }^{167}$ ASCENSÃO, José de Oliveira. Op. cit., p. 28.

${ }^{168}$ Ibidem, p. 30.

169 "Domínio público" no sentido de "patrimônio cultural".
} 
com alto grau cada elemento protegido componente de uma obra, seja literária, artística ou científica.

O plágio, ato violador de direito de autor, acontece no iter criativo. Um autor de má-fé se apropria dos elementos, no todo ou em parte, de uma obra preexistente protegida. Não é somente a usurpação de paternidade no sentido de suprimir o nome do autor da obra e substituir pelo próprio, mas também a valoração dos elementos subtraídos da obra preexistente que estão em questão.

Abaixo, analisaremos as três teorias mais conhecidas pela doutrina: a teoria da forma interna, forma externa e conteúdo; a teoria da identidade de representação e a teoria da ideia, composição e expressão.

\subsubsection{Teoria da forma interna, forma externa e conteúdo}

A teoria da forma interna, forma externa e conteúdo, segundo Vittorio Maria De Sanctis, foi influenciada na doutrina alemã pela filosofia hegeliana. ${ }^{170}$

Por seu turno, Zara Algardi diz que essa teoria é derivada da concepção francesa de ideia e forma externa. Para a doutrina francesa, a ideia, na linha dos juristas acima citados, tem sua origem no fundo comum, enquanto que a forma externa é a expressão individual do autor. ${ }^{171}$

De acordo com a teoria alemã, o conteúdo é o assunto ou tema, que por si sós não são protegidos pelo direito de autor. A forma interna é a organização do assunto ou tema, o modo como o autor trabalha e dispõe os elementos componentes da obra, dando um caráter pessoal ao conteúdo. Essa forma interna precisa ser exteriorizada de algum modo para que possa ser compreendida ou sentida por um destinatário — isto acontece por meio de traços, palavras, sons, constituindo a forma externa. ${ }^{172}$

\footnotetext{
${ }^{170}$ DE SANCTIS, Vittorio Maria. Il carattere creativo delle opere dell'ingegno. Milano: Giuffrè, 1971, p. 52, nota de rodapé n. 117.

${ }^{171}$ ALGARDI, Zara Olivia. Il plagio letterario e il carattere creativo dell'opera. Milano: Giuffrè, 1966, p. 316.

${ }^{172}$ TESTA, Ezio Spaziani. Le elaborazioni delle opere letterarie. In: Il Diritto di Autore, ano 30, n. 4, p. 543-616, out-dez, 1959, p. 547.
} 
No que tange à obra literária, o assunto é o conteúdo, oriundo da cultura de uma determinada época, sob a influência do ambiente em que o autor vive, sendo o que é comum ou acessível a qualquer pessoa. Por sua vez, a forma interna é a elaboração do conteúdo, o modo como o autor vai trabalhar o assunto, variando conforme a obra literária. Se for um romance, a sequência dos fatos narrados, os personagens, o desenrolar da história, contendo os traços pessoais na narrativa. Por fim, a forma externa é o estilo, a forma interna manifestada por meio de palavras, sons, em conformidade com os padrões gramaticais de uma determinada língua.

O elemento tutelável, segundo essa teoria, é a forma interna na qual está presente a originalidade no tratamento do assunto, isto é, o reflexo da personalidade do autor. Porém, a forma interna confunde-se com a forma externa, não sendo esta excluída da proteção autoral. Por isso, não é possível traçar um limite preciso entre a forma interna e a forma externa, bem como entre a forma interna e o conteúdo, matéria bruta para a criação do autor.

$\mathrm{Na}$ forma interna, segundo Kohler, há elementos pessoais do autor, fruto de seu trabalho criativo. Por outro lado, a forma externa é a maneira de expressão do autor. Uma das características da forma interna, consoante Kohler, é a conexão de elementos e o reagrupamento de ideias. Para exemplificar, Kohler diz que, no caso das obras literárias de drama e narração, a forma interna estaria presente no significado ideal ou na essência da narração compreensível nos personagens. ${ }^{173}$

Vittorio Maria De Sanctis critica a teoria da forma interna, forma externa e conteúdo no que se refere à sua finalidade. ${ }^{174}$ Nessa linha, Zara Algardi também diz que essa teoria embrenha em sutilezas filosóficas de pouco valor jurídico, sendo mais útil aos especialistas em criação intelectual de áreas diversas do que ao meio jurídico. ${ }^{175}$

Não divergimos dos posicionamentos desses autores, pois não é possível no exame, mesmo acurado, de uma obra extrair com precisão os elementos protegidos. Por outro lado, as invenções tuteladas pela propriedade industrial são de maior grau de objetividade, cujo

\footnotetext{
${ }^{173}$ ALGARDI, Zara Olivia. Op. cit., p. 317 e nota de rodapé n. 34.

${ }^{174}$ DE SANCTIS, Vittorio Maria. Il carattere creativo... Op. cit., p. 52.

${ }^{175}$ ALGARDI, Zara. Op. cit., p. 316.
} 
escopo são soluções técnicas no momento da criação. Destaca-se que um autor não procura soluções práticas para problemas da vida, mas expressar sentimentos, emoções, opiniões, enfim, exteriorizar o seu modo de compreender o mundo.

É muito comum, pelo menos entre as pessoas não instruídas ou alheias à seara autoral, dizer que a quantidade de trechos extraídos ou frases idênticas de uma obra preexistente configura o plágio. Também não é tarefa fácil distinguir entre os elementos componentes de uma obra literária a personalidade do autor. A par disso, não é função do juiz ou intérprete do Direito perscrutar o aspecto psicológico do autor.

\subsubsection{Teoria da identidade de representação}

Na linha da teoria da forma interna, forma externa e conteúdo, Eduardo Piola Caselli, entusiasta da inserção dos direitos morais de autor na Convenção de Berna, propõe a teoria da identidade de representação.

A crítica de Eduardo Piola Caselli sobre a teoria da forma interna, forma externa e conteúdo não diverge da opinião de Vittorio Maria De Sanctis e Zara Algardi, pois não há como traçar um limite preciso entre os elementos componentes de uma obra. ${ }^{176}$

O elemento comum, independente da espécie de obra, para Eduardo Piola Caselli é o caráter representativo. Tal caráter é sentido no todo de uma obra tutelada, não apenas em determinados elementos. ${ }^{177}$ A função do Direito, para esse autor, é a tutela de obras no seu todo, ao invés de separar quais elementos da obra são protegidos. ${ }^{178}$

Acrescenta Eduardo Piola Caselli que as obras têm uma finalidade. A tutela do direito de autor se esgota na proteção da forma de representação destinada ao público. ${ }^{179}$ De fato, a criação estética tende, como outras criações, a um resultado. No entanto, o autor tem a faculdade de não exibir ou comunicar ao público a sua criação, podendo mesmo impedir que seja revelada no exercício de seu direito ao inédito.

\footnotetext{
${ }^{176}$ CASELLI, Eduardo Piola. Trattato del Diritto di Autore. 2. ed. Torino: Unione Tipografico-Editrice Torinese, 1927, p. 75.

${ }^{177}$ Ibidem, p. 77.

${ }^{178}$ Ibidem, p. 77-78.

${ }^{179}$ Ibidem, p. 77.
} 
O problema da teoria da identidade de representação na questão do plágio, conforme expõe Zara Algardi, é a tônica no elemento da exteriorização, não considerando o elemento subjetivo na criação intelectual. ${ }^{180}$

Questão não abordada por Eduardo Piola Caseli é o momento em que se inicia a tutela das obras. Não excluímos a proteção, no caso de obras literárias, de rascunhos, esboços, textos incompletos, e, acima de tudo, de obras inéditas. Nesse sentido, diz Tullio Ascarelli ao tratar da criação do autor, que um estágio criativo destinado a ser uma obra, não deixa, enquanto inacabado, de ser uma obra protegida. ${ }^{181}$

Aliás, sob o ponto de vista estritamente do Direito de Autor positivado, como vimos nos capítulos anteriores, não há uma definição de obra, tanto na legislação brasileira como nas convenções internacionais. O rol das obras protegidas é exemplificativo. Da mesma forma, não há uma enumeração ou definição de quais partes de uma obra são protegidas, independente de ser literária, artística ou científica. Vale lembrar que os incisos I e II do art. $7^{\text {o }}$ da Lei n. 9.610/1998 exemplificam quais são as obras literárias protegidas. Nesse passo, a lei exclui certos objetos, como dispõe o inciso IV do art. $8^{\circ}$ da Lei $n$. 9.610/1998 sobre os atos oficiais e decisões judiciais.

Logo, a teoria da identidade de representação tenta simplificar o tratamento das partes tuteláveis da obra, enfocando-a como um todo orgânico sem entrar em detalhes como a teoria da forma interna, forma externa e conteúdo. Como se nota, Eduardo Piola Caselli buscou um modo mais objetivo de analisar a tutela da obra, sem correr o risco de ingressar no seu mérito.

\subsubsection{Teoria da ideia, composição e expressão}

Sobre as etapas da criação da obra literária, Henri Desbois diz que são as ideias, a composição e a expressão:

\footnotetext{
${ }^{180}$ ALGARDI, Zara. Op. cit., p. 627-628.

${ }^{181}$ ASCARELLI, Tullio. Teoria della concorrenza e dei beni immateriali. 3. ed. Milano: Giuffrè, 1960, p. 710.
} 
Quais são as etapas pelas quais o escritor atinge o fim de sua missão? Ele começa concebendo ideias; depois, essas ideias, ele as compõe, buscando a transformação, o plano mais apropriado para valorizar, de maneira a comunicar aos leitores sua conviçção, seus sentimentos, suas emoções, suas sensações. Depois de ter escolhido o molde apropriado, vem a expressão. Ideias, composição e expressão, eis o esquema das etapas de uma criação literária. ${ }^{182}$.

Henri Desbois enfatiza que a pedra angular na apreciação de obras contrafeitas é a composição. $^{183}$

Entre nós, Hermano Duval também diz que o elemento para identificação de plágio literário é a composição. Segundo Hermano Duval, a composição é:

[...] a maneira de ser do autor; é o modo pelo qual êle sente e descreve determinado tema ou episódio. Ora, como dificilmente dois autores descreverão o mesmo assunto do mesmo modo, uma vez que cada um dar-lhe-á sua feição pessoal, segue-se que não será através a identidade do tema que se há de identificar o plágio, mas, obviamente, através a semelhança da composição do plagiador com o autor original. Haverá, portanto, plágio - quando houver semelhança no tratamento da composição da obra plagiada; salvo quando, pela própria natureza da obra (Anatomia, Geografia etc.), sua composição não comportar tratamento diverso. Conseqüentemente, ao contrário do que sustentam GARRAUD, POUILLET, LUIGI DI FRANCO E BENTO DE FARIA, já é possível fixar-se na composição o elemento de fundo que distingue o plágio da obra nova independente. Embora retomando dois elementos conhecidos (idéia e forma de expressão), a segunda obra só será nova e autônoma se sua composição se diversificar da anterior, porque só na composição é que seu autor terá oportunidade de se mostrar diferente ou original. ${ }^{184}$.

De fato, a composição é a etapa da criação autoral na qual é possível identificar traços da personalidade do autor. Não obstante isso, Henri Lucas destaca que a originalidade pode variar dependendo da obra literária. No caso das traduções, a originalidade está mais presente na expressão, enquanto que nas antologias na composição. ${ }^{185}$ Como se observa, a aplicação da teoria da ideia, composição e expressão,

\footnotetext{
${ }^{182}$ DESBOIS, Henri. Op. cit., p. 11. tradução nossa e itálicos no original. No original: "Quelles sont les étapes, par lesquelles un écrivain parvient à l'achèvenement de sa tâche? Il commence par concevoir des idées; puis, ces idées il les compose, cherchant l'aménagement, le plan le mieux approprié à les mettre en valeur, à communiquer aux lecteur sa conviction, ses sentiments, ses émotions, ses sensations. Après avoir choisi le moule approprié, il en vient à l'expression. Idées, composition, expression, voilà le schéma des étapes d'une création littéraire."

${ }^{183}$ Ibidem, p. 43.

${ }^{184}$ DUVAL, Hermano. Violações dos direitos autorais. Rio de Janeiro: Borsoi, 1968, p. 102. Itálicos no original.

${ }^{185}$ LUCAS, André; LUCAS, Henri-Jacques. Op. cit., p. 75.
} 
bem como da teoria da forma interna, forma externa e conteúdo, varia conforme a obra, mesmo entre as obras literárias.

Pensamos que composição não é apenas organizar os elementos de uma criação intelectual - como dispor os livros numa estante. Na composição encontraremos o encadeamento de ideias e as convicções do autor, demonstrando traços de sua personalidade. Da mesma sorte, na forma interna estão presentes reflexos da personalidade do autor.

Por seu turno, na expressão poderemos encontrar mais o estilo, a linguagem e o modo, que não são protegidos pelo direito de autor, posto que são meios de elaboração. Contudo, o estilo também guarda a marca do autor. Imitar o estilo de um autor é lícito, pois ele pode ser o referencial de um determinado período. ${ }^{186}$

Hoje, existem programas de computador que realizam operações que, inicialmente, eram executadas apenas por seres humanos, v.g., a tradução de frases ou períodos ou até mesmo de um parágrafo.

A teoria da ideia, composição e expressão não difere muito da teoria da forma interna, forma externa e conteúdo. A composição e a forma interna são as partes protegidas pelo Direito de Autor. Igualmente, a forma externa e a expressão são os meios pelos quais o autor manifesta a sua criação. Por tais razões, ambas as teorias não são suficientes para demonstrar os elementos protegidos pelo Direito de Autor, o que nos leva a crer que, pela própria natureza das criações estéticas, plenas de subjetividade, não há como estabelecer os limites precisos dos elementos tuteláveis na obra.

\subsection{A originalidade}

A originalidade demonstra traços da personalidade do autor na obra. Trata-se de um critério subjetivo: encontrar os elementos criativos pessoais do autor.

Hoje, a originalidade é amplamente conhecida como requisito de proteção

${ }^{186}$ ALGARDI, Zara Olivia. Op. cit., p. 478. 
autoral. ${ }^{187}$ Henri Lucas diz que a jurisprudência francesa reconheceu tarde a noção de originalidade. Henri Desbois foi o primeiro a apresentar a noção de forma sistematizada. ${ }^{188}$

Henri Desbois afirma que: "Só, a forma, sob a qual a ideia foi apresentada, uma vez tomada a uma exclusividade, sob condição de ser original". ${ }^{189}$ Continua o jurista francês dizendo que o critério de originalidade é a pedra angular do Direito de Autor.

Por ser um critério subjetivo, a originalidade tem duas características: um caráter subjetivo e outro relativo. ${ }^{190}$

Henri Desbois exemplifica a característica subjetiva da originalidade na hipótese de duas telas sobre o mesmo objeto pintadas por artistas diferentes. O objeto é o mesmo para ambos, mas as impressões de cada um serão manifestadas de maneira diversa. ${ }^{191}$ Assim, Henri Desbois, por meio da hipótese, ressalta a exteriorização da personalidade do autor na criação intelectual.

A relatividade do requisito de originalidade está presente na qualificação da obra absolutamente original, que não tem origem em criação preexistente, e da obra relativamente original, obra derivada. ${ }^{192}$ Prossegue o jurista francês dizendo que é necessário contrastar as obras de natureza diversa na pesquisa de originalidade. ${ }^{193}$

Ademais, Pierre-Yves Gautier diz que o conceito de originalidade é o "vício fundamental" do Direito de Autor. Para contrastar o conceito de originalidade, Pierre-Yves Gautier propõe o conceito de banalidade. Banal, segundo este autor, é tudo que está no

\footnotetext{
${ }^{187}$ Em acórdão do Tribunal de Justiça do Estado de São Paulo não foi encontrada originalidade em suposto plágio de método de treinamento. Ementa: "Direito de autor. Trabalho científico destinado ao desenvolvimento das qualidades humanas - Obrigação de não fazer cumulada com pedido de indenização. Originalidade não caracterizada . Reconvenção - Danos morais Descabimento Improcedência da ação e da reconvenção - Recursos improvidos. (SÃO PAULO (Estado). Tribunal de Justiça. Apelação com Revisão n. 9068285-82.2006.8.26.0000. Apelantes: INEXH Instituto Nacional de Excelência Humana, Neil Hamilton Negrelli Júnior e João Paulo Kotzent. Apelados: João Paulo Kotzent, José Milton Kozent e INEXH Instituto Nacional de Excelência Humana. Relator: Des. Jesus Lofrano. $3^{\text {a }}$ Câmara de Direito Privado. São Paulo, 22 fev. 2011. Disponível em: <https://esaj.tjsp.jus.br/cjsg/getArquivo.do?cdAcordao=4974859\&vlCaptcha= BtRde>. Acesso em: 05 out. 2012).

${ }^{188}$ LUCAS, André; LUCAS, Henri-Jacques. Op. cit., p. 72.

${ }^{189}$ DESBOIS, Henri. Op. cit., p. 4.

${ }^{190}$ Ibidem, p. 4.

${ }^{191}$ Ibidem, p. 5.

${ }^{192}$ Ibidem, p. 9.

${ }^{193}$ Ibidem, p. 11
} 
fundo comum da cultura. ${ }^{194}$ Banalidade, consoante o Dicionário Houaiss da Língua Portuguesa: "Banalidade. Substantivo feminino. [...] 2 condição ou atributo do que é banal; insignificância, trivialidade". ${ }^{195}$

Cremos que a contraposição dos conceitos de originalidade e banalidade também não auxilia muito o intérprete na identificação do elemento criativo do autor, sendo ambos conceitos muito relativos.

Portanto, o critério de originalidade, assim como as teorias expostas acima sobre a identificação da obra, não são precisos na determinação da proteção dos elementos criativos que mostrem os traços da personalidade do autor na obra.

\subsubsection{A originalidade e a novidade}

Os vocábulos "originalidade" e "novidade" têm sentido semelhantes, prestando-se a equívocos no que se refere ao requisito de individuação criação intelectual. Tanto é que o Dicionário Huaiss assim os define:

Originalidade. Substantivo feminino. 1. qualidade do que é inusitado, do que não foi ainda imaginado, dito, feito etc.; inovação, singularidade; [...]

Novidade. Substantivo feminino. Caráter, condição, atributo do que é novo; 1. condição do que aparece, do que se apresenta pela primeira vez; 1.1. condição do que é original, extraordinário, do que resulta de uma invenção ou do que é produto do inusitado por não haver sido ainda imaginado, dito, feito etc.; inovação, originalidade; 1.2. tudo aquilo que é produto da criação artística, imaginativa, esp. no campo da arte, da cultura, da música etc. $[\ldots]^{196}$.

Não são somente as definições, transcritas acima, que levam as pessoas a crer que a criação intelectual, sobretudo a criação estética, deva ser original ou nova, como também a doutrina.

Henri Desbois destaca duas diferenças básicas entre a criação estética e a técnica. $\mathrm{O}$ conceito de originalidade é subjetivo, ao passo que o de novidade é objetivo. Tais

\footnotetext{
${ }^{194}$ GAUTIER, Pierre-Yves. Propriété littéraire et artistique. 7. ed., Paris: PUF, 2010, p. 48-49.

${ }^{195}$ DICIONÁRIO ELETRÔNICO Houaiss da Língua Portuguesa .Versão 2009.4. Rio de Janeiro: Objetiva, 2009. Negrito no original.

196 Ibidem, negritos no original.
} 
conceitos são, podemos dizer, a distinção fundamental das criações autorais e industriais. $^{197}$

De igual modo, Newton Silveira sublinha que a originalidade é um critério subjetivo, enquanto que a novidade é objetiva. Vale aqui transcrever a distinção de Newton Silveira: "Objetivamente novo é aquilo que ainda não existia; subjetivamente novo é aquilo que era ignorado pelo autor no momento criativo". 198

O Direito Industrial guarda muitas semelhanças com o Direito de Autor, principalmente por tutelar a criação do ser humano. Contudo, as criações estéticas e as criações técnicas têm natureza, tutela e destinação diversas. A destinação das criações estéticas é transmitir sentimentos, pensamentos, impressões pessoais ao público, dependentes de um juízo de valor estético daquele que as recebe, enquanto que as criações técnicas visam à solução de um problema utilitário, independentemente de valoração subjetiva. $^{199}$

Para se obter a proteção patentária, de modo diverso da proteção autoral, o invento deve ser analisado por órgão registrador de patente. Em nota de atualização à obra de João da Gama Cerqueira, Newton Silveira diz que "a patente confere o direito de exclusivo". 200 Isto é muito relevante na distinção da disciplina do Direito de Autor, que não exige o registro para que a obra seja protegida, ao passo que no Direito Industrial é condição necessária para que o inventor possa ter a sua criação protegida. Vale lembrar que há juízo de valor para a concessão de uma patente de invenção.

Silmara Juny de Abreu Chinellato destaca que os direitos morais do inventor não são tão abrangentes como os do autor. ${ }^{201}$ Podemos exemplificar tal diferença na obrigatoriedade de constar o nome do autor na obra e em seus exemplares, quando não for anônima, e, no caso do inventor, a nominação na patente, ao invés de no produto.

A proteção das obras autorais independe de registro. Muitas pessoas, que não

\footnotetext{
${ }^{197}$ DESBOIS, Henri. Op. cit., p. 6.

${ }^{198}$ SILVEIRA, Newton. Direito de Autor no design. 2. ed. São Paulo: Saraiva, 2012, p. 101.

${ }^{199}$ DE SANCTIS, Vittorio Maria. Il carattere creativo... Op. cit., p. 23.

${ }^{200}$ CERQUEIRA, João da Gama. Tratado da Propriedade Industrial. Rio de Janeiro: Lumen Júris, 2010, v. 1, parte 1, p. 142. Atualização Newton Silveira e Denis Borges Barbosa.

${ }^{201}$ CHINELLATO, Silmara Juny de Abreu. Op. cit., p. 79.
} 
conhecem o Direito de Autor, pensam que o registro de obra é constitutivo de direito, isto é, como no Direito Industrial, em que o registro permite o exercício do direito de exclusivo. Isso faz com que muitos autores equivocadamente se sintam seguros pelo fato de terem registrado suas obras, o que não impede a ocorrência de plágios.

Cremos que essa visão equivocada é devida em grande parte pela influência do sistema de copyright estadunidense. Como dissemos no capítulo anterior, mesmo após a adesão dos Estados Unidos à Convenção de Berna, os Estados Unidos continuaram a estimular o cumprimento de formalidades. Entendemos que não é de imediato que uma formalidade observada durante muitos anos será desprezada, posto que é própria ao sistema jurídico de copyright daquele país, e acima de tudo, à cultura local.

Conquanto o registro seja facultativo para a proteção autoral (art. 19, da Lei n. 9.610/1998), é prudente registrar a obra autoral para ser um meio de prova em eventuais litígios. A função do registro no sistema de Direito de Autor brasileiro é dar publicidade à obra, o que não é condição, pois no nosso ordenamento jurídico há disposição expressa sobre a dispensa de registro (art. 18 da Lei n. 9.610/1998), bem como sobre o direito ao inédito (inciso III do art. 24 da Lei n. 9.610/1998).

A novidade objetiva é um requisito, além da originalidade para a proteção da obra, no pensamento de Tullio Ascarelli. Segundo este autor, o requisito de originalidade para a proteção da obra não é suficiente para individuá-la. Tullio Ascarelli, na perspectiva da doutrina dos bens imateriais, diz que é impossível justificar a tutela no momento da criação intelectual, importando o resultado criativo. Por isso, é necessária uma novidade objetiva, que distingue a obra de outras existentes. ${ }^{202}$ Do mesmo modo, Tullio Ascarelli, como vimos acima, entende que os esboços e rascunhos são protegidos enquanto obras, mas no sentido de um todo não concluído.

Nesse passo, Paolo Greco e Paolo Vercellone afirmam que uma obra é original se, visto o seu conjunto orgânico, for o resultado da atividade criativa do autor, revelando a sua personalidade. ${ }^{203}$ Mais adiante, Paolo Greco e Paolo Vercellone sustentam que o

\footnotetext{
${ }^{202}$ ASCARELLI, Tullio. Op. cit., p. 705-706.

${ }^{203}$ GRECO, Paolo; VERCELLONE, Paolo. I diritti sulle opere dell'ingegno. In: Trattato di Diritto Civile italiano. Torino: Unione Tipografico-Editrice Torinese, 1974, v. 11, t. 3, p. 49.
} 
critério para a proteção da obra é a novidade objetiva, sendo a originalidade um sintoma aparente desta. A proteção é admitida até que se mostre a preexistência de uma obra não diversa. $^{204}$

Balmes Vega Garcia, ao estudar a contrafação de patentes, diz que a novidade, no âmbito do Direito Industrial, "é relativa aos meios que constituem a invenção, não sendo aplicada aos resultados ou às vantagens procuradas pelos citados meios". ${ }^{205}$

O conceito de novidade objetiva, a nosso ver, não é um requisito que melhora a interpretação da questão da criatividade, tornando-o ainda mais confuso. O conceito de novo em relação ao que existe objetivamente não é diferente do conceito de originalidade em oposição ao de banalidade. Se banal é aquilo que está presente na cultura, difuso no ambiente cultural, de outra parte, novo é aquilo que não existia. Não há no conceito de novidade, bem como no de originalidade, precisão no momento de comparar duas obras ou estabelecer o que é novo no ilimitado ambiente cultural.

Ressalta-se que no Direito Industrial, para a concessão de patentes, é necessário também verificar o estado da técnica. O estado da técnica, segundo Balmes Vega Garcia, "é considerado no seu conjunto, entendido como síntese teórica dos conhecimentos adquiridos no domínio considerado". ${ }^{206}$ Cabe a análise do estado da técnica ao experto de um domínio do conhecimento, não sendo um homem médio ou leigo que avalia em conformidade com critérios subjetivos de gostos e predileções. O experto vai buscar nos conhecimentos hauridos num determinado domínio técnico os critérios objetivos de valoração para saber o que é novo em relação ao já existente numa área específica.

Infelizmente, não há, no âmbito da cultura, como ocorre no âmbito tecnológico, fatores objetivos para separar o que é novo do já existente. Hoje, na denominada "sociedade da informação", a situação piora, posto que a difusão de obras em meio eletrônico não permite saber o que é novo no sentido de diverso do que existe e, muitas vezes, nem quem é o verdadeiro titular do direito sobre a obra. Vale lembrar que a proteção

\footnotetext{
${ }^{204}$ GRECO, Paolo; VERCELLONE, Paolo. Op. cit., p. 50.

${ }^{205}$ GARCIA, Balmes Vega. Contrafação de patentes. São Paulo: LTr, 2004, p. 24.

${ }^{206}$ Ibidem, p. 31.
} 
das obras independe de formalidades, ao contrário das criações técnicas, sobretudo as invenções. Logo, é impossível conhecer o que é novo na seara autoral.

Portanto, como já dissemos, pela própria natureza da obra, em oposição à invenção, não é possível mensurar com precisão o aporte criativo do autor, não importando, se for uma obra literária, se se trata de um romance, um poema, um sermão ou uma conferência. Em outras palavras, é melhor, como diz Pierre-Yves Gautier, o "vício fundamental” da originalidade no exame dos atributos pessoais do autor na obra, que o requisito de novidade.

\subsection{O mérito no Direito de Autor}

O Direito de Autor, a princípio, não questiona o mérito das criações estéticas. Isto se deve ao fato de o Direito de Autor não criar obstáculos para o desenvolvimento da literatura, artes e ciência. É necessário um mínimo de originalidade para que a criação intelectual possa ser protegida de eventuais violações. Desse modo, não cabe aos juízes a apreciação de valor estético das criações, isto é, verificar se uma obra é bela ou não, bem como impedir a circulação da obra por motivações ideológicas, religiosas ou políticas.

Gustave Huard afirma que, se o mérito fosse um critério para a proteção autoral, o legislador criaria um sistema de retribuição pela importância da obra. ${ }^{207}$

José de Oliveira Ascensão vê certa importância no mérito, a fim de combater a banalização de obras de pouco valor estético que aumentam os rendimentos de sociedades gestoras. Entretanto, José de Oliveira Ascensão pensa que o Direito de Autor não pode subordinar as criações intelectuais ao critério arbitrário do jurista quanto ao mérito. ${ }^{208}$

Não é o que ocorreu em muitas decisões da jurisprudência francesa. Caroline Carreau, em tese sobre o assunto, enumera em todo seu trabalho diversas decisões judiciais que consideraram o mérito. Dentre os muitos julgados, destacamos um julgado do Tribunal de Besançon, de 20 de fevereiro de 1902, no qual há a menção expressa do mérito: “[...] o mérito dele reside quase unicamente na forma literária sob a qual esse fato está

${ }^{207}$ HUARD, Gustave. Op. cit., p. 69.

${ }^{208}$ ASCENSÃO, José de Oliveira. Op. cit., p. 59. 
apresentado, na originalidade dos comentários, na revelação que fazem do pensamento do autor $[\ldots]]^{209}$

Caroline Carreau, ao estudar os julgados sobre contrafação, enfatiza que a busca de originalidade na suposta obra contrafeita sempre foi observada. ${ }^{210}$ A originalidade é o critério para a distinção entre a obra primígena e a contrafeita.

A propósito do mérito, Caroline Carreau compara a criação e o mérito:

A criação se entende principalmente como a marcha intelectual e seu produto, a obra mesma colocada na forma pelas concepções e atividade próprias do espírito de seu autor, podendo ser as qualidades e os defeitos. Ela é de alguma maneira neutra, somente a sua existência é suficiente para ter a proteção legal.

Ao contrário, o mérito é contingente, ligado a um juízo de valor influenciado por considerações de oportunidade tais como o gosto e a moda. Estranho a permanência que busca o Direito, ele se situa por natureza nas altas esferas da estética onde se desenha o julgamento da posteridade. ${ }^{211}$.

No julgamento de plágio, não importando qual espécie de criação intelectual em questão, será quase impossível não adentrar no mérito das obras em confronto no fito de avaliar se há violação na obra supostamente plagiada. Claro, esclarecemos que não se trata de qualificar sob o ponto de visto da crítica especializada, mas verificar se há elementos suficientes para concluir se existe ou não a apropriação de criação alheia com usurpação de paternidade.

Logo, comparar duas criações do espírito é confrontar ambas. É verificar a originalidade de cada uma. Ademais, não há como não haver um juízo de valores de quem avalia no exame das provas de um caso de plágio, principalmente se for uma obra fruto de plágio com adição de novos elementos criativos. Entretanto, não é possível comparar com

\footnotetext{
${ }^{209}$ CARREAU, Caroline. Mérite et Droit d’Auteur. Paris: LGDJ, 1981, p. 238.

${ }^{210}$ Ibidem, p. 91

${ }^{211}$ Ibidem, p. 262. Tradução nossa. No original: “La création s'entend principalment comme la démarche intellectuelle et son produit, l'ouvre elle-même mise en forme par les conceptions et l'activités de l'esprit propres à son auteur, quelles qu'em puissent être les qualités ou les défauts. Elle est em quelque sorte neutre, son existence suffisant à elle seule à metre en action la protection légale. A l'opposé, le mérite est contingent, lié à un jugement de valeur influencé par des considérations d'opportunité telles que les goût et la mode. Etranger à la permanence que recherche le Droit, il situe par nature dans les hautes sphères de l'esthétique ou se dessine le jugement de la postérité."
} 
isenção total de gostos ou preferências duas obras, independentemente de ocorrência de plágio. 


\section{O PLÁGIO LITERÁRIO}

\subsection{A contrafação e o plágio}

O conceito autoral de contrafação foi sendo construído pela doutrina francesa ao longo do século XIX. Muitas vezes o plágio foi incluído no conceito de contrafação ou houve apenas sutis distinções entre ambos. Vale lembrar que o Código Penal de 1890, no art. 350 , e a Lei n. 496 , de $1^{\circ}$ de agosto de 1898 , no art. 19 , definem a contrafação como violação dos direitos de autor.

Augustin-Charles Renouard, nos primórdios do Direito de Autor, diz que a expressão "contrafação" prevaleceu sobre "contrefaction", que foi utilizada na legislação francesa. Define Augustin-Charles Renouard a contrafação: “[...] é o nome legal das violações do direito de autor". ${ }^{212}$ Analisando a etimologia do vocábulo "contrafação", Renouard diz que nem sempre ocorre uma contrafação por meio de uma "façon" (fabricação) ilegítima. ${ }^{213}$

O plágio, de acordo com Augustin-Charles Renouard, não era punido como a contrafação. ${ }^{214} \mathrm{O}$ mesmo jurista diz que é difícil determinar o limite entre o plágio e a contrafação. ${ }^{215}$ Ainda conforme Augustin-Charles Renouard, o plágio é assimilado à contrafação se houver prejuízo pecuniário ao autor. Não ocorrendo tal prejuízo, o plágio viola somente o "amour-propre" do autor. Prossegue Renouard dizendo que "As imitações de obras de outrem somente se justificam num tribunal: do gosto". Enfim, Renouard distingue entre a contrafação, ofensa ao Direito Civil; o plágio, ofensa moral; e a imitação servil, ofensa aos preceitos de gosto. ${ }^{216}$

Antônio Chaves, em época mais recente, ao analisar a distinção entre o plágio e a contrafação, afirma que há como examinar um sem se referir à outra. O plágio é uma ofensa de natureza civil, enquanto que a contrafação, de natureza penal com aspecto mais

\footnotetext{
${ }^{212}$ RENOUARD, Augustin-Charles. Op. cit., t. 2, p. 10. Cf. GASTAMBIDE, Adrien-Joseph. Op. cit, p. 96.

${ }^{213}$ RENOUARD, Augustin-Charles. Op. cit., t. 2, p. 11.

${ }^{214}$ Ibidem, p. 22.

215 Ibidem, p. 22.

${ }^{216}$ Ibidem,, p. 21-23. Tradução nossa. No original: “Les imitations des ouvres d'autri ne se justifient qu'un tribunal: du goût".
} 
econômico. ${ }^{217}$ Não seguimos a opinião de Antônio Chaves sobre a distinção de natureza civil e penal entre a contrafação e o plágio, uma vez que o plágio, como violação de direito de autor, não está excluído da tutela penal. Cabe lembrar, como já dito anteriormente, que o Código Penal vigente, no art. 184, pune qualquer violação aos direitos de autor.

Édouard Calmels afirma que Charles-Augustin Renouard extraiu o entendimento da impunidade do plágio da opinião do Advogado Geral M. Daniel, com base na natureza de propriedade do direito de exclusivo do autor. Na transcrição de Édouard Calmels da opinião de M. Daniel, este diz que não cabe aos tribunais julgarem a questão do plágio quando não houver prejuízo pecuniário, mas ao público e aos jornais, que farão justiça ao autor vítima de plágio. Conclui que é mais uma questão de fato que de direito. ${ }^{218}$

No início do século XX, Gustave Huard reconhece a ilicitude do plágio quando um escritor atribui a si a paternidade de uma obra que não é criação sua ou da qual participou apenas de uma parte. Todavia, adverte em nota de rodapé: "Por plágio entendemos às vezes a imitação de uma importância muito medíocre para que possa ver os feitos de contrafação". ${ }^{219}$

Eugène Pouillet, ao abordar o plágio, parece ter consciência da originalidade como critério de distinção no julgamento das obras plagiadas. Entretanto, Eugène Pouillet, como os seus contemporâneos, ainda está preso ao critério de existir contrafação para que possa ocorrer uma violação autoral, como segue:

É aqui que a questão do dano pode ter sua utilidade; se a imitação é tão bem dissimulada, tão habilmente misturada às partes originais que se torna quase impossível reconhecer sob novas vestes que a cobrem, e que o autor da obra imitada não deva sofrer nem na sua reputação, nem na sua fortuna, o juiz poderá decidir que o plágio não vai até a contrafação. Não queremos dizer, como certos julgados, que o plágio difere da contrafação pela extensão, pela importância material das imitações, pois esta regra nos parece longe de ser verdadeira em todos os casos. Com efeito, pode o plagiador ter tomado somente um pequeno número de passagens, mas que essas passagens, sobretudo se se trata de uma obra filosófica ou científica, sejam precisamente aquelas que dão à obra seu caráter de originalidade

\footnotetext{
${ }^{217}$ CHAVES, Antônio. Op. cit., p. 406.

${ }^{218}$ CALMELS, Édouard. Op. cit., p. 639-640.

219 HUARD, Gustave. Op. cit., p. 296. Tradução nossa. No original: "Par plagiat on entend parfois des emprunts d'une importance trop mediocre pour qu'on puísse y voir des faits de contrefaçon".
} 
própria, como o miolo, ou, em casos parecidos, importaria a quantidade de imitações; é à sua qualidade, à sua natureza, que é necessário olhar. ${ }^{220}$

Podemos verificar que, nas opiniões dos juristas franceses acima, o plágio era um ato reprovável no âmbito moral, sem nenhuma sanção jurídica. No entanto, se houvesse elementos que caracterizassem a contrafação, o plagiador seria condenado. Édouard Calmels nos leva a crer que caberia aos críticos e à opinião pública o julgamento do plágio, sendo irrelevante para a apreciação dos tribunais. Segundo tais opiniões, cremos que não havia, como hoje na doutrina, não só francesa como de outros países de sistema romanogermânico, uma consciência mais clara dos direitos da personalidade, em especial dos direitos morais de autor.

Nesse sentido é o entendimento de Zara Algardi, que, após analisar a doutrina francesa do período que acabamos de expor, conclui que não havia um desenvolvimento do conceito de direitos morais de autor. Os juristas franceses e a jurisprudência daquele período viam somente uma lesão ao direito de exclusivo de caráter econômico. ${ }^{221}$

Não obstante, Henri-Jacques Lucas afirma que hodiernamente o debate sobre o plágio e a contrafação ainda se encontram entre os domínios do Direito e da Moral. Prossegue Henri-Jacques Lucas dizendo que sempre houve uma tradição literária de tolerância em relação ao plágio, chegando este jurista a citar escritores clássicos franceses, Anatole France e Lautréamont, que faziam apologia do plágio, excluindo o meio dos escritores. $^{222}$

Entre nós, Carlos Alberto Bittar também destaca o caráter patrimonial da violação de contrafação em oposição à ofensa aos direitos morais de autor no plágio. ${ }^{223}$ No mesmo

\footnotetext{
${ }^{220}$ POUILLET, Eugène. Op. cit., p. 406-407. Tradução nossa. No original: "C'est ici que la question de dommage peut avoir son utilité; si l'emprunt est si bien dissimulé, si habilement mêlé à des parties originales qu'il devienne presque impossible de le reconnaître sous les nouveaux habits don til se couvre, et qu'em fait l'auteur de l'ouvrage imité n'en doive souffrir ni dans as réputation, ni dans sa fortune, le juge pourra décider que le plagiat ne va pas jusqu'à la contrefaçon. Nous ne voulons pas dire, avec certains arrêts, que le plagiat diffère de la contrefaçon par la longueur, par l'importance matérielle des emprunts, parce que cette règle nous semble loin d'être vraie dans tous les cãs. Il se peut, en effet, que le plagiaire n'ait pris qu'un petit nombre de passages, mais que ces passages, surtout s'il s'agit d'une ouvre philosophique ou scientifique, soient précisément ceux qui donnent à l'ouvrage son caractère d'originalité propre, et qui en sont commes la moelle; or, en pareil cãs, qu'importerait la quantité des emprunts; c'est la leur qualité, à leur nature, qu'il faudrait regarder".

${ }^{221}$ ALGARDI, Zara Olivia. Op. cit., p. 312.

${ }^{222}$ LUCAS, André; LUCAS, Henri-Jacques. Op. cit., p. 242.

${ }^{223}$ BITTAR, Carlos Alberto. Direito de Autor. 4. ed., Rio de Janeiro: Forense Universitária, 2008, p. 149.
} 
sentido, Teixeira dos Santos também distingue o plágio da contrafação pelo caráter pecuniário desta. O plágio é a simulação de originalidade por artifícios formais sem finalidade de lucro. ${ }^{224}$

Giorgio Jarach, lastreado no uso da jurisprudência italiana, diz que é indiferente a distinção entre plágio e contrafação, uma vez que ambos são apropriações de obra alheia. $^{225}$

Por seu turno, Zara Algardi, comentando a jurisprudência francesa do século XIX, afirma que no plágio haveria o elemento subjetivo, não reprimível, enquanto que na contrafação haveria a violação na reprodução não autorizada de obra protegida. ${ }^{226}$

Podemos dizer que o dano do plágio não toca somente o direito patrimonial de autor, mas, com maior gravidade, o direito à paternidade e de integridade à obra. É certo, porém, que quantificar ou qualificar a extensão do dano sofrido pelo autor importa em tarefa de difícil avaliação.

O sentido de contrafação na França, de acordo com o vigente Code de la Propriété Intellectuelle, é de uma violação de caráter patrimonial. O art. L. 335-2 do referido diploma, diz: “Toda edição de escritos...", não divergindo muito da definição da lei autoral brasileira. ${ }^{227}$ Contudo, o art. L 335-2 diz que "[...] toda contrafação é um delito".

Vimos no capítulo segundo, dedicado ao exame das leis brasileiras que regulamentam a matéria autoral, que o sentido de contrafação, desde a Lei n. 5.988/1973, é de reprodução não autorizada (inciso V do art. $4^{\circ}$ ). A Lei n. 9.610/1998, no inciso VII do art. $5^{\circ}$, manteve a definição de contrafação. A reprodução, definida no inciso VI do art. $5^{\circ}$ da Lei n. 9.610/1998, é: “a cópia de um ou vários exemplares de uma obra literária,

\footnotetext{
${ }^{224}$ SANTOS, N. P. Teixeira dos. O fazer literário e a lei. In: Revista de Informação Legislativa. Brasília: Senado Federal, v. 26, n. 102, abr./jun. 1989, p. 253. Disponível em: <http://www2.senado.gov.br/ bdsf/item/id/181920>. Acesso em: 06 jul. 2011.

${ }^{225}$ JARACH, Giorgio. Manuale del Diritto d'Autore. Milano: Mursia, 1968, p. 303-304.

${ }^{226}$ ALGARDI, Zara. Op. cit., p. 304.

227 FRANÇA. Code de la Propriété Intellectuelle. Disponível em: <http://www.legifrance.gouv.fr/ telecharger_pdf.do?cidTexte=LEGITEXT000006069414>. Acesso em 10 jul. 2012. Artigo L 335-2 do Code de la Propriété Intellectuelle: "Toute édition d'écrits, de composition musicale, de dessin, de peinture ou de toute autre production, imprimée ou gravée en entier ou en partie, au mépris des lois et règlements relatifs à la propriété des auteurs, est une contrefaçon et toute contrefaçon est un délit".
} 
artística ou científica". Logo, a contrafação, na lei autoral brasileira vigente, não se confunde com o plágio, que não se limita a cópias de exemplares, mas, antes de tudo, de uma violação de direitos morais de autor.

A inserção dos direitos morais de autor, tanto na Convenção de Berna como nas legislações nacionais de países de tradição jurídica romano-germânica, contribuiu para aclarar a distinção entre o plágio e contrafação, uma vez que o aspecto econômico é mais evidente nesta que naquele.

Em última análise, o elemento subjetivo ou de caráter pessoal do autor é o primeiro a ser violado no plágio. $\mathrm{O}$ direito à integridade da obra é o primeiro a ser violado, pois o plagiador extrai os elementos de uma obra preexistente para elaborar uma nova obra, para depois usurpar a paternidade, atribuindo como sua uma obra posterior violadora. De resto, o fim de lucro não é o elemento essencial no plágio, pois o reconhecimento público e a ofensa à fé pública são o escopo do plagiador.

\subsection{A usurpação de paternidade e a usurpação de nome}

Malgrado tanto a usurpação de paternidade como a usurpação de nome envolva o direito da personalidade ao nome, ambas se diferenciam quanto aos fins.

Na usurpação de paternidade o agente visa enganar o público no fito de atribuir a si a paternidade de obra alheia. $\mathrm{O}$ agente quer ser reconhecido como autor de obra que não é de sua criação, não importando se deseja reconhecimento ou lucro.

Por outro lado, na usurpação de nome, o agente usa em suas obras o nome alheio com intuito de se beneficiar à custa de notoriedade ou renome de alguém. Assim, são situações inversas no que se refere ao uso do nome vinculado à obra.

É muito comum a usurpação de nome nas obras de artes plásticas. O falsificador, geralmente um artista de pouca fama ou expressão, utiliza o nome de artista consagrado para obter vantagem econômica. 
Na usurpação de nome o falsificador não quer nenhum reconhecimento público. Pelo contrário, quer que sua identidade permaneça oculta. Talvez fique satisfeito ao bem imitar um artista de muitos méritos e fama. ${ }^{228}$

O Código Penal brasileiro tipificava o crime de usurpação de nome ou pseudônimo alheio, no art. 185, revogado pela Lei n. 10.695/2003. Como já visto, hoje o tipo penal é mais abrangente ao dispor sobre a violação do direito autoral, tipo penal em branco, é o único artigo a disciplinar a violação do direito autoral

Consoante Paulo José da Costa Jr., o crime se consumava com a publicação ou exposição ao público, não importando se houvesse lesão. Era um crime de perigo. Quanto à culpabilidade, o crime era doloso. ${ }^{229}$

Tornou-se comum, principalmente na Internet, a usurpação de nome de pessoas notórias. Pela facilidade proporcionada ao público, de comunicação de textos ou de manifestar opiniões, sem o intermédio de um editor, a Internet é um campo fértil para usurpação de paternidade e usurpação de nome. Na rede global de computadores, nem sempre o usurpador de nome tem o fito de lucro, mas busca usurpar o nome de pessoas reconhecidas para lastrear seus comentários na opinião respeitada de autores conhecidos. ${ }^{230}$

Pontes de Miranda, ao examinar a cessão de paternidade disciplinada no revogado Código Civil de 1916, não distingue o direito ao nome do direito à paternidade. ${ }^{231} \mathrm{~A}$ existência do direito à paternidade está vinculada à existência de uma obra protegida pelo Direito de Autor. O direito ao nome, no âmbito dos direitos da personalidade, independe de uma criação intelectual, sendo o nome uma denominação distintiva de uma pessoa no meio social.

\footnotetext{
${ }^{228}$ COSTA JR., Paulo José da. Op. cit., p. 367-368.

${ }^{229}$ Ibidem, p. 368.

${ }^{230}$ Um exemplo de usurpação de nome na Internet demonstra que o usurpador do nome de renomado professor de Língua Portuguesa, Professor Pasquale Cipro Neto, não teve o cuidado de escrever o nome usurpado da forma correta, trocando as letras "qu" do prenome da vítima, por "co". (GLOBO COMUNICAÇÃO PARTICIPAÇÕES S/A. Bom Dia Brasil. Falsas citações, atribuídas a grandes autores, circulam na internet. São Paulo, 29 nov. 2011. Disponível em: <http://g1.globo.com/bom-diabrasil/noticia/2011/11/falsas-citacoes-atribuidas-grandes-autores-circulam-na-internet.html>. Acesso em 30 nov. 2011).

${ }^{231}$ PONTES DE MIRANDA, Francisco Cavalcanti. Op. cit., t. 16, p. 59.
} 
$\mathrm{Na}$ relação autor-obra verificada na usurpação de paternidade, elemento constitutivo do plágio, há uma obra preexistente protegida, enquanto que na usurpação de nome há uma obra que não é uma criação do autor nela nomeado. Na usurpação de nome, não há relação criativa entre o autor e a obra. Os fins do plagiador e do falsificador são distintos: o plagiador se apropria da criação alheia para apresentar ao público como própria, ao passo que o falsificador cria uma obra atribuindo a paternidade a outrem. $\mathrm{O}$ elemento comum entre o plágio e a usurpação de nome é a ofensa à fé pública, incutindo no público o que não é verdadeiro.

A obra com usurpação de nome tem a proteção autoral enquanto uma criação do espírito, embora sob o nome de pessoa alheia à criação intelectual. O dano, tanto na usurpação de paternidade como na usurpação de nome é, a princípio, moral. No entanto, a proteção da vítima de plágio está na seara autoral por haver um vínculo autor-obra na violação. Por outro lado, a usurpação de nome está situada no âmbito dos direitos da personalidade, pelo uso indevido do nome alheio.

Por conseguinte, mesmo havendo semelhanças no que tange ao nome na usurpação de paternidade e na usurpação de nome, o regime jurídico de cada violação é distinto. $\mathrm{O}$ plágio está no regime especial do Direito de Autor, enquanto que a usurpação de nome, no regime geral dos direitos da personalidade.

\subsection{Direitos violados}

Inicialmente, para que haja uma violação moral ou patrimonial aos direitos do autor, é conditio sine qua non a existência de uma obra de seu intelecto. Nesse sentido, vale mais uma vez lembrar que o Direito de Autor não protege as ideias.

Os direitos violados pelo ato violador do plágio, como já dito em outros pontos deste trabalho, são os direitos morais de autor. Não negamos que os direitos patrimoniais são violados. Mas não é sempre que um autor almeja lucro na publicação de uma obra, podendo ser vítima mesmo se a obra for inédita, caso em que a gravidade do plágio é maior. 
Vale destacar que os direitos morais de autor são inalienáveis, imprescritíveis e, acima de tudo, perpétuos. Em razão disso, mesmo após a morte do autor, os direitos morais de autor têm amparo jurídico contra qualquer violação. Entretanto, os direitos patrimoniais de autor deixam de existir, escoado o prazo de proteção post mortem, ingressando no domínio público.

Os direitos morais de autor estão no âmbito dos direitos da personalidade. Entretanto, como sublinha Agnès Lucas-Schoetter, os direitos da personalidade são intrínsecos ao seu titular, enquanto que os direitos morais de autor estão vinculados à obra, podendo, mesmo depois de publicada, não refletir mais a personalidade do autor. ${ }^{232}$ Cremos que tal afirmação encontra amparo no direito de retirada ou de arrependimento do autor, direito de retirar ou proibir a venda de exemplares de obra já publicada.

Os direitos morais de autor de paternidade e de integridade da obra são violados em qualquer plágio, pois o plagiador usurpa a paternidade ao exibir uma obra alheia como própria, não revelando a verdadeira fonte de consulta ou de inspiração para a criação de sua obra. Além disso, ao extrair os elementos de uma obra preexistente com o fito de elaborar outra obra, o plagiador funde os elementos tomados de obra preexistente, seja de modo explícito ou camuflado, no escopo de enganar o público.

\subsubsection{Direito à paternidade}

Ao usurpar a paternidade da obra, o plagiador quer apresentar ao público uma obra que não é de sua criação, não havendo um verdadeiro liame autor-obra no sentido de ser a manifestação do modo de ser e pensar de uma pessoa. Ao contrário, é uma imitação ou subtração de elementos significativos de uma obra preexistente, desprovida de elementos criativos próprios de uma pessoa, isto é, não existe, ou existe em parte, no cerne da obra plagiadora a revelação ou reflexos da personalidade do autor.

Usurpar a paternidade de uma obra pode ser, além do plágio, fazer uma cópia servil e excluir o nome do verdadeiro autor pelo do usurpador. Neste caso, cremos não ser um plágio, pois não é a usurpação de paternidade o único direito violado no ato do plagiador.

${ }^{232}$ LUCAS-SCHOETTER, Agnès. Droit moral et droits de la personalité: étude de droit comparé français et allemand. Aix-en-Provence: Presses Universitaire d'Aix-Marseille, 2002, t. 1, p. 209-210. 
Uma cópia servil, isto é, uma cópia literal, sem incluir ou excluir nenhum elemento criativo componente da obra preexistente, é uma violação de direito de autor, porém não é um plágio. ${ }^{233}$

Aliás, a usurpação de paternidade de obras no todo não é um fato incomum. Os recursos informáticos facilitam sobremaneira a cópia de obras inteiras através de mecanismos que efetuam a cópia em segundos, dispensando a cópia manual ou digitação.

No entanto, não podemos olvidar que o autor pode ocultar a sua identidade ao não revelar o seu nome, como ocorre no caso de obras anônimas. As obras anônimas são protegidas pelo Direito de Autor. Se o autor for vítima de plágio, será obrigado, na defesa de seu direito, a cessar o anonimato. Não há outro meio de verificar senão a revelação da identidade do autor na relação autor-obra. A propósito, o anonimato é uma faculdade do autor, deixando exclusivamente ao seu arbítrio a revelação de sua identidade nos casos de plágio, posto que não há uma usurpação de paternidade.

Entretanto, as obras pseudônimas, também protegidas pelo Direito de Autor, têm tratamento jurídico igual ao da obra com o nome que o autor é conhecido no meio social, isto porque é possível identificar o autor, que não é obrigado a usar o seu nome civil ou alcunha. A afinidade entre o anonimato e a pseudonímia é o ocultamento do nome civil ou nome usual pelo qual o autor é reconhecido. Porém, o autor se vale do pseudônimo por motivações de variada ordem, v.g., perseguições políticas, censura, escritos obscenos etc. Se for vítima de plágio ou usurpação de paternidade, o autor será obrigado a revelar a sua identidade civil, sobretudo se bater às portas do Poder Judiciário.

\subsubsection{Direito à integridade da obra}

Outro direito violado no ato plagiador é o direito à integridade da obra. Ninguém, sem o consentimento do autor, mesmo os herdeiros ou detentores de direitos de autor post mortem, não pode efetuar alterações na obra. Isto se deve ao fato de que a obra, criação estética e projeção da personalidade do autor, é um conjunto que não permite exclusões e inserções não pensadas pelo autor.

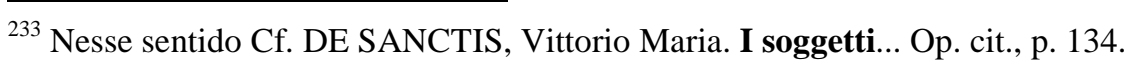


Cabe exclusivamente ao autor o direito de alterar ou modificar a sua obra. É da essência da obra ser um fruto de trabalho criativo, mesmo que tenha um mínimo de criatividade. A criação de uma obra literária passa por diversas fases, v.g., ideia inicial, criação dos personagens, o enredo, o ambiente, a redação, a organização das partes em capítulos ou parágrafos etc. Ainda durante a redação de um trabalho não concluído visando ser uma obra literária, pensamos que já exista a tutela do direito de autor, como dito por Tullio Ascarelli em relação à obra incompleta. ${ }^{234}$

No plágio, o plagiador não deixa de ser um autor, mas apropriador de elementos criativos de uma obra preexistente. O plagiador toma os elementos principais ou mais significativos da obra preexistente para elaborar a sua obra de maneira a dar a impressão de uma obra de cunho pessoal e desvinculada de obra preexistente. O fim do plagiador, como já dissemos, é enganar o público.

Frisa-se que a inspiração em obra preexistente é lícita. É impossível conceber qualquer obra literária do nada, sendo necessário partir ao menos de uma ideia. $\mathrm{O}$ ambiente no qual o autor está inserido, a sua formação intelectual, as suas impressões são a matériaprima para a construção de sua obra. Nessa vereda, as leituras, muitas vezes mais que as impressões do mundo que circunda o autor, são determinantes para a criação de uma obra literária, que necessariamente deverá espelhar a personalidade do autor.

Não é sem razão que os direitos patrimoniais de autor têm um prazo certo após morte do autor, a fim de permitir ao público o acesso às obras que formam a cultura de um povo ou a cultura universal. Por isso, dentre as limitações de direito de autor está o direito de citação, sendo lícita a extração de trechos de uma obra preexistente com indicação do seu autor.

No entanto, não lícito ao autor modificar ou criar uma sequência de obra preexistente em domínio público, pois os direitos morais de autor são perpétuos. A inspiração é lícita, mas não a apropriação de elementos criativos da obra em domínio público.

${ }^{234}$ ASCARELLI, Tullio. Op. cit., p. 710. 
O direito à integridade da obra é violado na extração de elementos criativos que foram concebidos pelo autor de obra preexistente. No entanto, não é fácil dizer com precisão quais são os elementos significativos de uma obra, v.g., um capítulo, o enredo, uma estrofe ou um verso, o tratamento semelhante do mesmo tema etc. O plágio varia conforme o gênero literário.

O mascaramento ou camuflagem com que o plagiador reveste os elementos criativos de uma obra preexistente podem ter elementos criativos próprios, uma vez que o plagiador pretende disfarçar o ato ilícito mediante a adição de elementos não presentes na obra preexistente. A propósito, o mascaramento pode melhorar ou tornar mais atraente os elementos extraídos de obra preexistente, o que não exclui a ilicitude do plágio. ${ }^{235}$ Ademais, como dissemos no capítulo anterior, o Direito de Autor não ingressa no mérito das obras.

A tradução, obra derivada em relação à obra original, pode violar o direito à integridade. O tradutor trabalha com a forma externa ou expressão, conforme as teorias de identificação da obra vistas no capitulo anterior. Pode ocorrer que o tradutor não encontre uma palavra na língua traduzida que tenha um sentido próximo ao da língua original, alterando o sentido daquilo que realmente o autor quis dizer. Essa situação piora no caso de autor morto.

Uma obra literária não está restrita a uma época. Por isso, a obra é passível de alterações de grafia. Vale lembrar que o Presidente da República Federativa do Brasil promulgou o Acordo Ortográfico da Língua Portuguesa - Decreto n. 6.583, de 29 de setembro de $2009 .{ }^{236}$ Assim, todas as obras literárias publicadas depois de 31 de dezembro de 2015, como dispõe o parágrafo único, do art. $2^{\circ}$, do Decreto n. 6.583/2009, incluindo as obras em domínio público, devem estar em conformidade com o padrão estabelecido pelo Acordo Ortográfico.

Em derradeiro, para a configuração do plágio, em qualquer espécie de obra, é conditio sine qua non a violação concomitante do direito à paternidade e do direito à

\footnotetext{
${ }^{235}$ Nesse sentido Cf. ALGARDI, Zara. Op. cit., p. 499.

${ }^{236}$ BRASIL. Decreto n. 6.583, de 29 de setembro de 2009. Op. cit.
} 
integridade da obra. Se não houver ambas as violações, não podemos afirmar que se trata de plágio, mas de violações independentes.

\subsubsection{Direito ao inédito}

Vimos acima que para ocorrência do plágio é necessário haver violação ao direito à paternidade e ao direito à integridade da obra. O plágio é agravado quando a obra violada for inédita, pois está na esfera privada do autor.

O autor não tem o dever de publicar sua obra, podendo publicar quando lhe convier ou, até mesmo, impedir a sua publicação depois de morto, exceto se manifestou expressamente em sentido contrário. ${ }^{237} E$ É uma faculdade do autor. $\mathrm{O}$ autor pode, por razões estritamente pessoais, não dar ao conhecimento público a obra.

Vale lembrar que a proteção da obra é automática, não sendo requisito para a tutela o registro. Por ser uma obra protegida, mesmo inédita, há uma violação. O registro, como dissemos anteriormente, retira o ineditismo da obra por torná-la pública.

Henri Desbois, ao discorrer sobre o denominado direito de divulgação, diz que a finalidade normal dos esforços do autor é tornar pública a obra, cabendo-lhe decidir o momento oportuno e os meios para publicá-la. ${ }^{238}$

A agravante do plágio de obra inédita é, além das violações abordadas nos itens anteriores, o desrespeito à vontade do autor de não tornar pública a obra. Não importa conhecer as razões do autor para não publicar a obra, v.g., uma obra que contenha revelações íntimas ou uma obra não concluída. A decisão de publicar a obra cabe ao autor.

O plagiador possivelmente é uma pessoa que frequenta a privacidade do autor, isto é, uma pessoa que goza da confiança do autor. Tomar os elementos criativos da obra de um autor que não deseja publicar a obra, usurpando a paternidade, é uma violação mais grave que no caso de uma obra publicada.

\footnotetext{
${ }^{237}$ Nesse sentido Cf. ALGARDI, Zara. Op. cit., p. 537.

${ }^{238}$ DESBOIS, Henri. Op. cit., p. 426.
} 
Por ser inédita uma obra plagiada nesta situação, não é de fácil verificação a paternidade, pois, muitas vezes, é conhecida somente pelo plagiador. É pior a situação se o autor não tiver nenhuma obra publicada, o que não permite conhecer melhor o seu pensamento ou as caraterísticas pessoais.

\subsection{Publicação da obra como elemento do plágio}

\subsubsection{Publicação da obra plagiadora}

O plagiador, ao violar os direitos morais de paternidade e de integridade da obra, tem um fim de levar ao conhecimento do público a obra violadora.

Os interesses do plagiador podem ser muitos, como: conquistar reconhecimento público, utilizar de modo violador dos elementos criativos de uma obra consagrada pelo público, auferir eventuais ganhos pecuniários etc.

A questão é saber se o plágio pode ocorrer em obra violadora inédita. Acabamos de ver que o autor, independente de ser um violador de direito de autor, não tem o dever de publicar a obra, decidindo a ocasião que lhe for melhor. Pode acontecer, no caso de plagiador morto, que um herdeiro ou detentor de direitos sobre a sua obra venha a publicála. Não haveria como punir penalmente, mas somente na esfera cível, mediante uma indenização e recolhimento dos exemplares ou a retirada de sítio eletrônico. Cabe aqui indagar se o plagiador tinha intensão de publicar ou se a condição de plagiador depende da publicação.

Ao manter a obra inédita, o autor quer exercer um direito moral de preservar a obra do conhecimento do público. Se o autor for plagiador, presume-se que se arrependeu do ato violador ou não teve a oportunidade de mostrar ao público a sua obra. Assim, não há como perscrutar a intensão do autor.

Frisa-se que é conditio sine qua non para ser autor a existência de uma obra. Não há autor se não houver obra, inédita ou publicada. A obra, para ser plagiada, deve ser tutelada pelo Direito de Autor. Não há plágio se a obra não for protegida. Além disso, uma obra supostamente plagiadora é uma obra como qualquer outra até que se prove a violação. 
Cremos que a publicação da obra seja um elemento do plágio. Hipótese muito rara é o plagiador manter a obra inédita. A usurpação de paternidade e a extração de elementos criativos significativos, no todo ou em parte, da obra plagiada são as duas violações essenciais no plágio.

O plágio, sob o ponto de vista penal, consuma-se com a publicação. Nesse sentido, afirma Zara Algardi que o plágio é um delito instantâneo, consumando na publicação. ${ }^{239}$ Por seu turno, Paulo José da Costa Jr., ao examinar o crime de usurpação de nome ou pseudônimo, crime revogado do Código Penal brasileiro pela Lei n. 10.695/2003, diz que o crime se consuma na publicação ou exposição ao público. ${ }^{240}$

O plágio, como violação de direito de autor, requer o elemento subjetivo doloso. ${ }^{241}$ Não importando o fim de lucro ou reconhecimento público, o plagiador age intencionalmente, extraindo elementos criativos de obra preexistente e usurpando a paternidade em direção a um fim certo: publicar ou mostrar uma obra plagiadora.

Não rejeitamos a hipótese de plágio por culpa. Todavia, como o inédito de obra plagiadora, o plágio culposo nos parece uma hipótese rara. Quem extrai elementos criativos de obra preexistente, usurpando a paternidade, geralmente não age sem o animus de lesar direito alheio. Pode ocorrer que alguém faça uma citação ou transcrição omitindo a paternidade por imprudência ou negligência. Porém, é necessário verificar se há como distinguir na obra a citação, embora sem menção de autoria, das opiniões pessoais do autor. Neste caso, não seria propriamente um caso de plágio, mas de usurpação de paternidade por imprudência ou negligência.

Hoje, sobretudo no meio acadêmico, não cabe dizer que há plágio por imperícia. A maioria dos cursos superiores tem em seus programas a disciplina de metodologia do trabalho científico, que permite o conhecimento dos padrões de redação de um trabalho acadêmico lastreados nas normas autorais.

\footnotetext{
${ }^{239}$ ALGARDI, Zara. Op. cit., p. 680.

${ }^{240}$ COSTA JÚNIOR, Paulo José da. Op. cit., p. 368.

${ }^{241}$ Nesse sentido Cf. ALGARDI, Zara. Op. cit., p. 682.
} 
Logo, para a ocorrência do plágio, não importando a espécie de obra tutelada, é mister a usurpação de paternidade, a extração de elementos criativos da obra preexistente, no todo ou em parte, com ou sem modificações, bem como a publicação ou exposição da obra ao público.

\subsubsection{Negociações anteriores ao contrato de edição}

Para publicar a obra, o autor carece de um meio pelo qual todos tenham acesso à sua criação. No caso da obra literária, o autor pode se valer de recursos que dispensam o intermédio do editor, v.g., efetuar as cópias por si mesmo mediante o uso de máquinas copiadoras ou disponibilizar a obra em sítio eletrônico. A decisão de dar ao conhecimento do público a obra cabe sempre ao autor, posto que pode exercer o seu direito ao inédito.

O meio tradicional para publicar uma obra literária é a edição. Vimos que tanto o Estatuto da Rainha Ana como a Lei Le Chapellier deslocaram da esfera do editor para a do autor os direitos sobre a publicação da obra, sobretudo os aspectos patrimoniais.

Antes de concluir o contrato de edição entre autor e editor, o autor faz uma proposta ao editor para a publicação da obra. A proposta do autor pode ser recebida pelo editor por qualquer meio: um telefonema, conversa pessoal ou por meio de correio eletrônico. Contudo, as negociações anteriores ao contrato de edição, de modo diverso de outros negócios jurídicos, têm a particularidade do envio necessário de uma cópia ou o do próprio original da obra para que o editor possa aceitar a proposta.

Ressalta-se que a Lei n. 9.610/1998, bem como a Lei n. 5.988/1973, não disciplinam a formação do contrato de edição. Na ausência de disciplina específica na lei autoral, faz-se mister a aplicação das disposições do Código Civil em relação à formação do contrato de edição.

Vale lembrar que o Código Civil adotou o sistema da expedição (art. 1.080 do CC/1916 e art. 427 do CC/2002). ${ }^{242}$ A redação do art. 427 do CC/2002 é idêntica à do

${ }^{242}$ Cf. BEVILACQUA, Clóvis. Direito das obrigações. 6. ed., Rio de Janeiro: Francisco Alves, 1945, p. 161. Revisão e atualização Achilles Bevilacqua. 
estatuto anterior. A proposta, segundo o sistema adotado pelo Código Civil, vincula o proponente até uma resposta do aceitante.

A fase de negociação anterior ao contrato de edição tem particularidades. O autor envia, por qualquer meio, uma cópia ou a própria obra original para que o editor possa ler e avaliar se lhe é conveniente publicá-la. Antes de enviar uma mensagem de aceitação ou demonstrar por meio de um ato a intenção de publicar a obra, o editor ou seu auxiliar pode agir de má-fé ao plagiar a obra enviada pelo autor. Os motivos para plagiar podem variar conforme os interesses editoriais, v.g., o autor não goza de prestígio, o que leva o editor a usurpar a paternidade e a violar a integridade da obra enviada em favor de autor que não frustre os ganhos e atenue os riscos da edição.

A leitura de uma obra, dependendo do tema abordado e de sua extensão, pode demandar muito tempo do editor. Por outro lado, o autor, vinculado ao editor até a resposta positiva ou negativa de editar a obra, não pode propor para outros editores. Frisa-se que ainda não há um contrato de edição concluído.

Entre nós, Fábio Maria De-Mattia dedicou uma obra sobre o contrato de edição. Afirma Fábio Maria De-Mattia que a ruptura das negociações enseja indenização, embora ainda não exista um contrato gerador de direitos e obrigações entre as partes. ${ }^{243}$

Durante as negociações preliminares ao contrato é preciso observar o princípio da boa-fé, como dispõem os arts. 113 e 422 do Código Civil brasileiro. Cremos que o princípio da boa-fé não se restringe apenas ao contrato concluído e à sua execução, sendo um princípio a ser observado na fase anterior à conclusão do contrato. A boa-fé, nas tratativas anteriores ao contrato de edição, é um comportamento ético legitimamente esperado por cada uma das partes. Se o editor tentar plagiar a obra enviada pelo autor, perpetrará uma ofensa aos direitos morais de autor, bem como ao princípio da boa-fé.

Enzo Roppo, ao analisar as negociações no Código Civil italiano, diz que a ruptura nas negociações gera a responsabilidade pré-contratual. Porém, consoante o mesmo autor, é necessário a ocorrência de dano à parte lesada. Não há um vínculo contratual, mas "uma

${ }^{243}$ DE MATTIA, Fábio Maria. O autor e o editor na obra gráfica. São Paulo: Saraiva, 1975, p. 90. 
legítima confiança na conclusão do contrato". ${ }^{244}$ A pré-responsabilidade está lastreada na boa-fé.

A obra enviada para o editor é geralmente inédita. Malgrado o editor esteja de posse de cópia ou original da obra, isto não faz perder o caráter de ineditismo da obra. $\mathrm{O}$ editor tem o dever de sigilo, pois não é obrigado a publicar a obra, mas também não pode frustrar os interesses do autor no caso de resposta negativa. Aliás, a obra não foi publicada ou conhecida do público antes da edição.

Por seu turno, o autor não deve prejudicar o editor ao lhe enviar obra plagiadora. Agindo desse modo, o autor lesa os direitos do autor de obra originária, bem como o editor, por não agir de boa-fé no envio de obra plagiadora.

O registro da obra antes de um contrato de edição pode não ser muito interessante ao editor, posto que a obra deixa de ser inédita. Todavia, é uma medida de segurança do autor, que eventualmente pode se valer do registro no caso de ruptura das negociações para demonstrar uma violação de plágio em juízo.

A violação de direito de autor no plágio é inicialmente moral. Mensurar a dimensão do dano não é tarefa fácil, principalmente antes da conclusão de um contrato de edição. Se ocorrer o plágio, o autor pode pleitear indenização, posto que é ato violador de direitos morais. Dizemos isto porque há uma obra tutelada, mesmo que ainda não seja objeto de contrato de edição.

Assim, as negociações entre o autor e o editor requerem de ambos o dever de boafé, no fito de evitar violações ao direito de autor. Por seu turno, o editor tem o dever de sigilo, uma vez que não está obrigado, se não concluir o contrato de edição, a publicar a obra e distribuir os seus exemplares.

\subsection{A identificação do plágio pelas semelhanças entre as obras}

O plágio é revelado mais pelas semelhanças que pelas diferenças entre as obras. A

${ }^{244}$ ROPPO, Enzo. O contrato. Tradução de Ana Coimbra e M. Januário C. Gomes. Coimbra: Almedina, 2009, p. 107. 
comparação entre as obras supostamente plagiada e supostamente plagiadora mostrará os elementos criativos de cada autor.

É corrente a ideia de que o plágio, parcial ou total, é identificado tão somente no confronto de trechos ipsis litteris entre duas obras. Como destaca Hermano Duval, o teste das paralelas ou "parallel-hunters" não é suficiente para a detecção do plágio, demonstrando partes, mas sem considerar o todo. ${ }^{245}$ De acordo com as teorias de identificação da obra, vistas no capítulo anterior, o teste das paralelas está restrito à forma externa ou expressão, não bastando para demonstrar os traços pessoais de cada autor. Mutilam-se as obras para verificar a quantidade de trechos semelhantes entre elas.

Não nos parece um meio adequado o teste das paralelas para a identificação de plágio, sobretudo em obra literária. As teorias que abordamos brevemente no capítulo anterior nos levam a crer que a análise do plágio não se restringe a extrair trechos ipsis litteris entre duas obras, mas, antes de tudo, verificar os elementos criativos das obras no modo de tratamento pessoal do autor.

O plágio, segundo José de Oliveira Ascenção, "não é cópia servil; é mais insidioso, porque se apodera da essência criadora da obra sob veste ou forma diferente". ${ }^{246}$ Por isso, o exame do plágio não pode se restringir somente à comparação entre trechos ipsis litteris.

Destaca Vittorio Maria De Sanctis que um critério, seguido pela jurisprudência italiana, buscava mais a distinção de elementos pessoais no confronto de cada obra, ao invés de verificar os elementos criativos indevidamente apropriados na obra supostamente plagiadora. $^{247}$

De fato, não podemos perder de vista no confronto entre as obras supostamente plagiada e supostamente plagiadora a existência de elementos criativos extraídos indevidamente. No entanto, é quase impossível não existir em obra plagiadora algum elemento pessoal do plagiador, mesmo para tentar mascarar o ato violador. Desse modo, a individuação das obras vai demonstrar em diversos pontos o tratamento pessoal efetuado

\footnotetext{
${ }^{245}$ DUVAL, Hermano. Op. cit., p. 28.

${ }^{246}$ ASCENÇÃO, José de Oliveira. Op. cit., p. 34.

${ }^{247}$ DE SANCTIS, Vittorio Maria. Il carattere creativo... Op. cit., p. 61.
} 
por cada autor no fito de encontrar as semelhanças entre as obras, v.g., o enredo, a trama, os personagens, a divisão da obra, o título etc.

Balmes Vega Garcia, ao estudar a contrafação de patentes, também afirma que o exame da contrafação deve ser realizado considerando as semelhanças entre os objetos. No suposto objeto contrafeito deve haver os elementos essenciais do invento imitado, embora seja aparentemente diferente. ${ }^{248}$

Não podemos olvidar do patrimônio cultural na individuação de qualquer obra. Entende-se por patrimônio cultural, ou como prefere Zara Algardi, "patrimônio intelectual comum", o que é formado ao longo dos séculos por diversas contribuições individuais e coletivas, sendo algumas de origem remota e incerta. São contribuições que não pertencem a uma determinada pessoa, mas a um povo ou povos. ${ }^{249}$ Assim, os elementos do patrimônio cultural, por não serem protegidos como criação individual, são excluídos no confronto entre as obras supostamente plagiada e supostamente plagiadora.

Cabe aqui distinguir o patrimônio cultural do domínio público. As obras, depois de 50 anos após a morte do autor, segundo o caput do art. $7^{\circ}$ da Convenção de Berna, ou 70 anos, conforme o caput do art. 41 da Lei n. 9.610/1998, podem ser utilizadas independente de remuneração, ingressando no domínio público. Contudo, o autor, apesar de morto, pode ser vítima de plágio, pois os direitos morais de autor são perpétuos.

Resta saber se uma obra plagiadora subsiste se forem excluídos os elementos plagiados de obra preexistente. A princípio, qualquer obra é protegida se houver um mínimo de criatividade. A extração de um capítulo, dependendo da obra, pode não alterar o sentido de toda obra. Mas, o enredo ou um personagem pode comprometer toda obra. Logo, o exame de cada caso vai demonstrar o uso indevido de elementos essenciais de obra preexistente.

\subsection{Coincidências fortuitas e plágio}

No desenvolvimento de uma obra podem ocorrer coincidências fortuitas com outras

\footnotetext{
${ }^{248}$ GARCIA, Balmes Vega. Op. cit., p. 67-68.

${ }^{249}$ Nesse sentido Cf. ALGARDI, Zara. Op. cit., p. 604.
} 
preexistentes ou concomitantes. O patrimônio cultural é a fonte comum para a criação de uma obra. As questões em voga num determinado período histórico ou em uma escola literária, como o Romantismo, são elementos comuns que podem ser utilizados por qualquer autor na criação da obra. Reiteramos que é conditio sine qua non a busca dos traços pessoais do autor na obra, bem como, no exame do plágio, os elementos criativos extraídos indevidamente de obra preexistente.

O autor não cria uma obra completamente isento de influências culturais. Como qualquer pessoa, o autor está inserido num certo tempo e espaço, sendo passível de opiniões ou modismos. As obras consideradas clássicas, v.g., atuam de modo marcante na formação de um autor, posto que são consagradas por gerações anteriores e obrigatórias nas escolas. Em razão disso, o autor se inspira no que existe para criar uma obra de cunho pessoal.

Não é de todo estranha e incomum a existência de coincidência no tratamento de um assunto. Paolo Greco e Paolo Vercellone destacam que coincidências fortuitas perfeitas são raras em obras, diversamente das invenções que pressupõem um problema a ser solucionado, posto que o autor tem mais liberdade para criar uma obra. ${ }^{250}$.

Um conceito já referido neste trabalho é o de banalidade. No confronto entre as obras supostamente plagiada e supostamente plagiadora, a exclusão de elementos considerados banais é essencial. A banalidade não é protegida pelo direito de autor em oposição ao requisito de originalidade. Entende-se por banalidade o que é insignificante, desprovido de pessoalidade.

No exame das coincidências fortuitas, o contexto no qual o autor está inserido é o critério a ser seguido. Dois autores contemporâneos podem criar obras parecidas, influenciados por fatos e ideias de uma época. Assim, a exclusão de coincidências fortuitas no exame do plágio auxilia o leitor a encontrar os elementos pessoais de cada obra em confronto.

\footnotetext{
${ }^{250}$ GRECO, Paolo; VERCELLONE, Paolo. Op. cit., p. 46.
} 


\subsection{O "larcin imperceptible" e o plágio parcial}

A doutrina francesa denominou "larcin imperceptible" — podendo ser traduzido por "furto imperceptível" - a apropriação de trechos irrelevantes de obras literárias na criação de uma obra nova.

Como vimos acima, a doutrina francesa não via valor jurídico quando a violação não fosse uma contrafação, admitindo que o limite entre o plágio e a contrafação fosse de difícil delimitação. Vale lembrar que Édouard Calmels compara o plágio ao "larcin imperceptible". ${ }^{251}$ Isso, como também já dissemos, se deve ao fato de não haver naquele período uma noção clara dos direitos morais de autor.

O "larcin imperceptible" pode ocorrer na transcrição de trecho extraído de obra preexistente no fito de citação, que pode em certos casos não ter a referência da obra e do autor. Faz-se mister indagar se a obra com o trecho de obra preexistente subsiste independentemente do trecho incluído, ou se o trecho não tem muita importância num capítulo ou parágrafo. Claro, se a quantidade de trechos extraídos sem a referência ao autor, localizada na obra, for considerável estaremos diante de plágio.

Cabe dizer que há expressões comuns de uma área específica do conhecimento, bem como de uma determinada época. O emprego de tais expressões por qualquer pessoa não é protegido, posto que está no âmbito da cultura ou do domínio público.

No que se refere ao plágio parcial, perpetra-se na extração de certos elementos criativos de obra preexistente, mas de maneira a confundir ou ligar com outros elementos acrescentados pelo plagiador. Vittorio Maria De Sanctis afirma que pode acontecer o plágio parcial na extração de um personagem ou de um episódio de modo abusivo. ${ }^{252}$

Por outro lado, Zara Algardi critica a teoria da identidade de representação por não solucionar o plágio parcial, não considerando os elementos criativos não orgânicos da obra. ${ }^{253}$ De fato, um elemento criativo como um personagem secundário ou uma situação

${ }^{251}$ CALMELS, Édouard. Op. cit., p. 640.

${ }^{252}$ DE SANCTIS, Vittorio Maria. I soggetti... Op. cit., p. 135-136.

${ }^{253}$ ALGARDI, Zara. Op. cit., p. 630. 
presente em um capítulo de romance pode ser relevante, embora no conjunto da obra possa ser de menor importância.

No exame do plágio parcial, o elemento supostamente plagiado pode ser um "larcin imperceptible" indicado pelo autor supostamente plagiado como elemento criativo. Desse modo, se for um "larcin imperceptible" não haverá plágio parcial, posto que é um extrato inexpressivo. Porém, se for um elemento criativo de destaque no todo ou em parte da obra, a hipótese de plágio parcial pode ser considerada.

Por tais razões, a nosso ver, cabe perquirir se os elementos criativos desvinculados da obra supostamente plagiadora não a mutilam de maneira a tornar incompreensível ou se a obra subsiste independentemente do elemento criativo supostamente plagiado. Se a obra subsistir, caberá então avaliar a importância do elemento criativo supostamente plagiado em relação ao conjunto componente da obra.

\subsection{A proteção do título da obra, do índice e o plágio}

Os nomes e os títulos isolados, de acordo com o inciso VI do art. $8^{\circ}$ da Lei n. 9.610/1998, não são passíveis de proteção autoral. Por outro lado, o caput, do art. 10, da mesma lei, protege o título da obra, "se original e inconfundível com o de obra do mesmo gênero, divulgada anteriormente por outro autor".

O título pode ser idêntico dependendo da área do conhecimento. Um curso ou um manual pode ter o mesmo título por tratar-se de um mesmo tema, v.g., "Teoria Geral do Direito Civil", de Clóvis Bevilacqua e "Teoria Geral do Direito Civil", de Carlos Alberto da Mota Pinto. Os dois autores discorrem sobre a Teoria Geral do Direito Civil em épocas e países distintos, o primeiro no Brasil e o último em Portugal.

Outrossim, o título da obra está vinculado ao conteúdo. Outro exemplo de títulos idênticos é o clássico da Filosofia, "Cidade de Deus", de Santo Agostinho de Hipona, e o romance "Cidade de Deus", de Paulo Lins. Os conteúdos de cada obra são distintos, de modo a não confundir o leitor. 
Daniele Bonamore ressalta, em estudo dedicado à proteção do título de obra, que o título identifica a obra, mas também antecipa o seu conteúdo. Ainda consoante Daniele Bonamore, ninguém usurparia um título sem conteúdo, por não haver sentido. ${ }^{254}$

Nessa vereda, não podemos olvidar que ocorre de maneira semelhante com a proteção do nome. Rabindranath Valentino Aleixo Capelo de Souza diz que é ilícito o uso do nome de personalidade conhecida em anúncio ou em personagem fictícia. ${ }^{255}$ No mesmo sentido, Carlos Alberto Bittar enfatiza que o nome de pessoa física deve ser respeitado erga omnes. ${ }^{256}$

Realmente, tanto o título da obra como o nome de pessoa física têm o escopo de identificação. O fenômeno dos homônimos, ocorrente entre duas pessoas naturais, pode também acontecer entre dois títulos de obras. Todavia, mesmo havendo duas obras com títulos idênticos, o conteúdo irá distinguir cada obra. Ademais, as obras refletem os traços da personalidade do autor.

O índice de uma obra é a sua estrutura organizacional, sendo a divisão das partes componentes. Semelhante ao corpo humano, o índice é o esqueleto da obra. Assim, o índice separado da obra não subsiste, sendo apenas um plano geral sem conexão com o conteúdo.

Vale lembrar a teoria da identidade de representação, que procura identificar a obra no seu todo, ao invés das partes componentes isoladas. Pensamos que o índice, em conformidade com a teoria da identidade de representação, demonstra a organização da obra, mas sem revelar o conteúdo. Por isso, tal como o título, é necessário existir uma relação entre o índice e o conteúdo.

Há certas obras, como os manuais jurídicos, que seguem um índice de acordo com a divisão de uma lei. Vale lembrar os cursos de Direito Civil ou de Direito Processual Civil,

\footnotetext{
${ }^{254}$ BONAMORE, Daniele. Il plagio del titolo delle "opere dell'ingegno" nella dogmatica del Diritto d'Autore. Milano: Giuffrè, 2011, p. 83 e 126.

255 SOUZA, Rabindranath Valentino Aleixo Capelo de. O direito geral da personalidade. Coimbra: Coimbra, 1995, p. 250, nota de rodapé n. 572.

${ }^{256}$ BITTAR, Carlos Alberto; BITTAR FILHO, Carlos Alberto. Tutela dos direitos da personalidade e dos direitos autorais nas atividades empresariais. 2. ed., São Paulo: Revista dos Tribunais, 2002, p. 65. Revisão e atualização Carlos Alberto Bittar Filho.
} 
que são divididos conforme a disposição das matérias legisladas, v.g., Parte Geral e Parte Especial, Livro das Pessoas etc. Mesmo os manuais jurídicos, seguindo a divisão de uma lei, não terão coincidências perfeitas no tratamento de cada instituto ou das instituições, existindo opiniões pessoais de cada autor.

O plágio de título e de índice pode ocorrer quando o tratamento dado pelo plagiador for semelhante em muitos pontos em comparação à obra preexistente. A semelhança será apontada por não haver traços de pessoalidade do autor da obra supostamente plagiadora.

Resta verificar se uma obra plagiadora subsiste independente do título ou do índice plagiado. Com efeito, na análise do título e do índice é sempre necessário verificar o conteúdo. O título, o índice e o conteúdo são três elementos incindíveis na obra literária. Se houver muitas semelhanças de maneira a não tornar distinta a obra supostamente plagiada e a obra supostamente plagiadora, as semelhanças demonstrarão a existência de plágio.

Logo, não há plágio de título ou de índice isolado sem que exista conexão com o conteúdo da obra.

\subsection{O plágio inconsciente e o autoplágio}

Para existir plágio é necessário haver dolo. O plagiador extrai elementos criativos de obra preexistente para a criação de outra supostamente original. Não é um ato involuntário, isto é, inconsciente ou sem intenção de violar os direitos à paternidade e à integridade da obra.

De fato, há pessoas com capacidade de memorização de trechos de obras, o que não quer dizer que tais trechos sejam de sua criação. Um ator, v.g., memoriza o texto de uma peça teatral ao interpretar um personagem. Contudo, muitas vezes é obrigado a improvisar ao esquecer um trecho da peça, realizando o denominado "caco". Isto demonstra que o ser humano não é um papel em branco, sendo passível de esquecimento. Aliás, o caco é tolerado dentro de certos limites, pois seria uma violação ao direito à integridade o caco em trechos significativos da obra teatral. 
Da mesma maneira, não é possível o denominado autoplágio. Vimos no primeiro capítulo deste trabalho que o plágio significava na Antiguidade o furto de pessoas livres ou escravas sob o poder de alguém. Por extensão, o sentido de plágio tornou-se o furto de obra alheia. A propósito, mesmo no Direito Penal, é impossível o furto de objetos de nossa propriedade por nós mesmos.

Quem aproveita trabalho próprio anterior comunicado ao público, como adverte Silmara Juny de Abreu Chinellato, deve seguir as regras para citação pertinentes a qualquer autor. Destaca ainda Silmara Juny de Abreu Chinellato que a questão do autoplágio é, na verdade, a ausência de ineditismo da obra. ${ }^{257}$

Vimos acima que o direito ao inédito cabe exclusivamente ao autor. No entanto, é o ineditismo da obra o cumprimento de exigências dos interesses editoriais ou acadêmicos. Cabe, como ressalta Silmara Juny de Abreu Chinellato, verificar se o cerne da obra anterior foi aproveitado para a criação de obra pretensamente inédita. ${ }^{258}$ Não haverá ineditismo se o cerne ou o elemento principal da obra anterior comunicada ao público for utilizado em obra posterior.

A propósito do autoplágio em contrato de edição, Vittorio Maria De Sanctis comenta que na doutrina alemã há o denominado "Selbstplagiat", que consiste em cessão de direitos ao editor por autor de obra pretensamente nova contendo muitos elementos de obra anteriormente publicada pelo mesmo autor por outro editor. ${ }^{259}$

Aproveitar um ou outro elemento de obra própria anterior, a nosso ver, em trabalho posterior não retira o caráter de ineditismo. Contudo, como na análise do plágio, resta verificar se o conjunto dos elementos extraídos de obra própria anterior para a criação da obra posterior é idêntico. Se o for não se tratará de obra original inédita.

Por conseguinte, não há possibilidade de ocorrer o plágio inconsciente, pois o dolo é elemento essencial do ato ilícito, bem como o autoplágio é mais uma questão de ineditismo que de plágio propriamente dito.

${ }^{257}$ CHINELLATO, Silmara Juny de Abreu. Notas sobre plágio e autoplágio. In: Revista do Instituto dos Advogados de São Paulo. São Paulo: Revista dos Tribunais, n. 29, p. 305- 328, jan./jun. 2012, p. 325.

258 Ibidem.

${ }^{259}$ DE SANCTIS, Vittorio Maria. I soggetti... Op. cit., p. 124. 


\subsection{Paródia, pastiche e paráfrase}

A paródia, o pastiche e a paráfrase são usos livres não proibidos pelo Direito de Autor. Elemento comum na paródia, no pastiche e na paráfrase é o estilo, que não é protegido pelo Direito de Autor. Por isso, tais usos ensejam um campo maior para ocorrência do plágio, por não dependerem de autorização prévia do autor, como ocorre nas traduções e adaptações.

A definição de “estilo" constante no Dicionário Eletrônico Houaiss da Língua Portuguesa é:

\footnotetext{
Substantivo masculino [...]

rubrica: artes plásticas, arquitetura, música e literatura. conjunto de tendências e características formais, conteudísticas, estéticas etc. que identificam ou distinguem uma obra, um artista etc., ou determinado período ou movimento; conjunto de traços que identificam determinada manifestação cultural."
}

O estilo, de acordo com a teoria de Kohler, está na forma externa, bem como, na teoria de Henri Desbois, na expressão. ${ }^{260} \mathrm{~A}$ forma externa e a expressão não são partes protegidas pelo Direito de Autor, ao contrário da forma interna e da composição.

A paródia é uma imitação de obra preexistente, mas com um tom crítico ou humorístico. Ela é tutelada como obra originária, apesar de ter uma relação substancial com outra obra. É essencial na paródia uma relação de identidade com a obra parodiada de maneira a causar riso. No entanto, pode um autor, sob pretexto de parodiar uma obra, perpetrar o plágio, extraindo elementos criativos de modo a não criar uma obra nova.

Vittorio Maria De Sanctis relata que certos autores sustentaram que, para não haver plágio em paródia, seria necessária a citação do nome do autor da obra parodiada. ${ }^{261}$ Todavia, cremos que seja desnecessária essa citação, pois a identidade entre a obra parodiada e a paródia é o motivo de crítica ou de sátira.

\footnotetext{
${ }^{260}$ Cf. DESBOIS, Henri. Op. cit., p. 288.

${ }^{261}$ DE SANCTIS, Vittorio Maria. I soggetti... Op. cit., p. 141.
} 
Por sua vez, o pastiche é a imitação do estilo de alguém. Criar um pastiche é escrever "a maneira de outrem". Também aqui, como na paródia, a forma externa ou a expressão são os elementos utilizados pelo autor. Se o autor extrair elementos criativos com características pessoais de obra preexistente, haverá possibilidade de ocorrer o plágio.

Enfim, a paráfrase que é reescrever um texto com outras palavras ou escrever um texto com tema diferente seguindo o mesmo estilo. Não há ilicitude no uso da paráfrase, pois tanto o tema como o estilo não são protegidos pelo Direito de Autor. Contudo, como a paródia e o pastiche, alguém pode alegar que o uso de paráfrase para ocultar ou dissimular um plágio.

\subsection{O plágio é uma questão de fato}

O plágio, como vimos nos capítulos sobre a disciplina legal do Direito de Autor, tanto nacional como internacional, não foi legislado. Somente o Peru, em lei revogada expressamente, definiu o plágio, bem como a Espanha, no Código Penal vigente, menciona o plágio entre outras violações autorais. Há no Projeto de Lei n. 236/2012 — que reforma o Código Penal de 1940, de iniciativa do Senado Federal — no $\S 1^{\circ}$ do art. 172, tipo penal denominado de "plágio intelectual". Destacamos que não houve anteriormente em nosso país uma tentativa de inserir em lei uma disposição sobre o plágio, não importando a espécie de obra violada.

Dissemos em tópico especialmente dedicado ao Projeto de Lei n. 236/2012, do Senado Federal, que não somos partidários da existência de um tipo penal denominado “plágio intelectual". Ao invés disso, preferimos uma norma penal em branco, deixando à lei especial disciplinar sobre as violações autorais.

Não é tarefa fácil, como já visto no capítulo anterior, identificar os elementos criativos de uma obra, tampouco mensurar o quanto foi subtraído de uma obra para a criação de outra. Isto se deve à natureza das criações estéticas, plenas de subjetividade, ao contrário das criações técnicas que visam à solução de problema prático.

O requisito de originalidade, por sua vez, também não é de clara compreensão. Como verificar o mínimo de originalidade de uma obra? Não há como precisar o aporte 
criativo sem existir um juízo de mérito de quem avalia, posto que é um critério subjetivo.

Desse modo, o plágio, ato violador de direito de autor, não pode ser verificado senão no acurado exame entre duas obras: a supostamente plagiada e a supostamente plagiadora. Vale lembrar o critério relativo proposto por Henri Desbois ao discorrer sobre o requisito de originalidade. Faz-se mister comparar duas obras para saber os traços pessoais do autor, mesmo que não esteja em questão o plágio.

Tal exame é, antes de tudo, uma questão de fato. Nesse sentido, Édouard Calmels, como visto acima, diz que é uma questão de fato por não caber aos tribunais o exame do plágio, mas à opinião pública. No entanto, Édouard Calmels fez tal afirmação numa época em que ainda não havia uma disciplina dos direitos morais de autor, o que impelia os autores da matéria a enfocar toda violação autoral no aspecto eminentemente econômico.

Por seu turno, Zara Algardi diz que é comum na doutrina autoralista a opinião de que o plágio é uma questão de fato, mas examinada no mérito por critérios jurídicos. ${ }^{262}$

É possível estabelecer o que é o plágio na sua essência e dimensão? Cremos que não é possível, pois cada caso apresentará as suas particularidades, sendo que, muitas vezes, não haverá plágio ou qualquer outra violação ao direito de autor. Por isso, o plágio será verificado no confronto entre duas ou mais obras, tanto em sede judicial como administrativa.

Frisa-se que a acusação de plágio, por si só, já enseja no espírito de qualquer pessoa um juízo prévio da ocorrência do fato, mesmo antes do confronto entre as obras em questão. Por isso, cabe indagar se estamos diante de uma obra tutelada pelo Direito de Autor, pois, se não o for, não há que se pensar em plágio. O acusador, de sua parte, deve ter ciência de que, ao menos, boa parte do conjunto de sua obra foi utilizada de maneira fraudulenta na criação de outra obra. Destacamos que o acusado, se não houver plágio, pode processar criminalmente por calúnia, uma vez que o plágio, como violação autoral, está abrangido no disposto no art. 184 do Código Penal - o crime de violação de direito autoral.

${ }^{262}$ ALGARDI, Zara. Op. cit., p. 645. 
Portanto, o plágio será identificado como fato ilícito mediante o exame das obras, de modo a demonstrar as semelhanças e diferenças pessoais na criação de uma obra. Por isso, veremos no próximo capítulo o estudo da prova em relação ao plágio, em especial literário. 


\section{A PROVA DO PLÁGIO LITERÁRIO}

\subsection{Acusação de plágio}

Ouvem-se constantemente notícias de acusação de plágio de muitos autores, não importando o âmbito, seja no meio literário, seja no meio acadêmico. Antes de tudo, resta saber se há realmente um plágio.

A ignorância de muitas pessoas sobre o Direito de Autor, sem excluir os operadores do Direito, enseja acusações desprovidas de sentido de violação aos direitos do autor. Vimos até aqui que o Direito de Autor tutela as criações do espírito ou criações estéticas. Com razão, Silmara Juny de Abreu Chinellato afirma que a ignorância da seara autoral faz com que assuntos alheios sejam inseridos em discussões da matéria. ${ }^{263}$

O Direito de Autor, reiteramos, não tutela ideias e não é toda criação que é uma obra, objeto de proteção do Direito de Autor. A aplicação das disposições legais e doutrinárias retira do foco da violação muitas situações supostamente violadoras. Assim, o operador do Direito tem condições de verificar se existe uma violação autoral.

Ressalta-se que uma acusação de plágio por si só já incute no espírito de qualquer pessoa um prejulgamento, sendo mais grave que outras acusações de fato ilícito. Por isso, toda acusação de plágio deve ser bem examinada de acordo com o Direito de Autor.

Os operadores do Direito, especialmente os advogados, devem ter uma atenção extrema antes de ingressar com uma ação indenizatória fundada em plágio, uma vez que sua identificação não é uma tarefa fácil, mesmo para quem seja especialista ou conheça rudimentos do Direito de Autor. Dizemos isto para evitar uma possível lide temerária, isto é, uma pessoa busca em juízo a reparação de um direito que pensa ter sido violado, mas na verdade não o foi. Nesse passo, destaca-se que o subjetivismo inerente às criações do espírito propicia considerações muitas vezes lastreadas em caprichos.

Por conseguinte, o ensino do Direito de Autor, principalmente nos cursos jurídicos,

${ }^{263}$ CHINELLATO, Silmara Juny de Abreu. Notas sobre plágio e autoplágio... Op. cit., p. 326. 
proporcionaria melhor formação intelectual, evitando lides temerárias e instauração de procedimentos administrativos desnecessários. Infelizmente, o Direito de Autor, ao contrário de outras matérias, ainda não é ensinado em boa parte dos cursos jurídicos, o que aumenta as acusações de plágio e de outras violações autorais.

\section{$6.2 \mathrm{O}$ ônus da prova}

A prova do plágio, não importando o gênero da obra, é difícil. Não é incomum a busca de um parâmetro preciso para definir o que é o plágio. Uns procuram definir o plágio pela semelhança da forma externa ou expressão entre duas obras, enquanto outros pela quantidade de ocorrências semelhanças entre as obras. Na verdade, não há como saber o que é o plágio sem um exame das obras supostamente plagiadora e supostamente plagiada. Para tanto, faz-se mister a prova do fato violador de direito de autor denominado plágio.

Cabe à vítima do suposto plágio a prova do fato, em conformidade com o inciso I do art. 333 do Código de Processo Civil. Cândido Rangel Dinamarco, lastreado na lição de Chiovenda, diz que "o ônus da prova incumbe à parte que tiver interesse no reconhecimento do fato a ser provado". ${ }^{264}$ Realmente cabe à suposta vítima de plágio provar o fato ilícito mediante a juntada aos autos de exemplar ou cópia de sua obra e da obra supostamente plagiadora. Por conseguinte, como dissemos anteriormente, a publicação ou a comunicação ao público da obra supostamente plagiadora é um elemento essencial para a configuração do plágio, uma vez que o suposto autor plagiado deve tomar conhecimento do fato ilícito ao verificar a extração indevida de elementos criativos de sua obra em obra supostamente plagiadora.

Outrossim, como preceitua Vittorio Maria De Sanctis, se o ônus da prova do plágio coubesse ao réu supostamente plagiador, seria na maioria dos casos uma "probatio diabolica", criando grandes obstáculos para o réu negar a acusação. ${ }^{265}$

Obviamente, uma acusação de plágio lastreada apenas em boatos ou notícias infundadas geraria uma série de dificuldades para o julgador. Também não há como

\footnotetext{
${ }^{264}$ DINAMARCO, Cândido Rangel. Instituições de Direito Processual Civil. 6. ed., São Paulo: Malheiros, 2009, v. 3, p. 71. Itálicos no original.

${ }^{265}$ DE SANCTIS, Vittorio Maria. I soggetti... Op. cit., p. 139.
} 
verificar a ocorrência de plágio se não houver o corpus mechanicum das obras supostamente plagiadora e supostamente plagiada.

Logo, a suposta vítima de plágio deve demonstrar em juízo ou em outra instância o fato ilícito, respaldado em argumentos autorais. O objeto da prova do plágio limita-se na demonstração da extração indevida do conjunto ou de parte significante dos elementos criativos componentes da obra supostamente plagiada.

\subsection{Os meios de prova}

O Código de Processo Civil enumera e disciplina, a partir do art. 332, os meios de prova: o depoimento pessoal, a confissão, a exibição de coisa ou documento, a prova documental, a prova testemunhal e a prova pericial. No entanto, o art. 332 traz disposição genérica sobre os meios de prova, o que não exclui as denominadas provas atípicas, ou seja, provas admitidas mas não disciplinadas pelo Código de Processo Civil.

O depoimento pessoal da suposta vítima de plágio e do suposto plagiador serão importantes no convencimento da ocorrência de plágio. Cabe sublinhar que o comportamento das partes pode esclarecer certos pontos, v.g., uma pessoa que crê ser um gênio ou possuidor de talento excepcional sem discernir o que está no patrimônio comum cultural. Por outro lado, também o comportamento da parte, de dissimulação ou esquivamento no interrogatório, independente de ser autor ou réu, é um elemento importante para o julgamento da causa.

No caso de revelia, se o autor instruiu a petição inicial com a obra supostamente plagiada e a obra supostamente plagiadora, não haverá os seus efeitos. Isso porque inicialmente os direitos violados pelo plágio são direitos morais de autor: direito à paternidade e direito à integridade. Consoante comentário ao inciso II do art. 320 do Código de Processo Civil, José Joaquim Calmon de Passos diz que não incide o art. 319, subsistindo ao réu, se comparecer tempestivamente, o direito à contraprova. ${ }^{266}$

Cremos que seria raro uma pessoa confessar ter cometido plágio. Não obstante, o

\footnotetext{
${ }^{266}$ PASSOS, José Joaquim Calmon de. Comentários ao Código de Processo Civil. Rio de Janeiro: Forense,
} 1974, v. 3, p. 366. 
art. 351 do Código de Processo Civil dispõe que "Não vale como confissão a admissão, em juízo, de fatos relativos a direitos indisponíveis". Aqui, como no caso da revelia, a confissão não vale por se tratar de violação aos direitos morais de autor. No entanto, pondera Cândido Rangel Dinamarco que a eficácia da confissão fica excluída, o que não quer dizer que o teor da confissão não possa ser apreciado pelo juiz. ${ }^{267}$

Por seu turno, a exibição de coisa ou documento, a nosso ver, fica excluída da prova do plágio. Dizemos isto porque cremos ser necessário o conhecimento da vítima da violação autoral. A vítima do plágio deverá tomar conhecimento do fato violador mediante a leitura completa da obra supostamente plagiadora, ao invés de ter acesso somente a trechos esparsos, o que obrigaria a se valer da exibição de coisa ou documento. Como já sustentamos, a publicação ou comunicação ao público da obra supostamente plagiadora é condição para a configuração do plágio. Alguém que comete plágio raramente deixaria a obra no ineditismo.

Ademais, a prova testemunhal também não será de grande valia no conjunto probatório do plágio. Pensamos que uma testemunha pode não esclarecer o fato imputado, baseando-se somente em notícias, muitas vezes inverídicas, como somente dizer qualidades a respeito de uma das partes no processo. Todavia, cabe ao juiz a conveniência de inquirir e ouvir as testemunhas arroladas pelas partes. Frisa-se que os elementos criativos extraídos ilicitamente de obra protegida estarão presentes em outra obra supostamente plagiadora, ao invés de informações levadas a juízo por testemunhas.

Dentre os meios de prova do plágio, pensamos que a prova documental e a prova pericial são as mais importantes.

De acordo com Cândido Rangel Dinamarco, documento "é todo ser composto de uma ou mais superfícies portadoras de símbolos capazes de transmitir ideias e demonstrar a ocorrência de fatos". 268

A obra, a princípio, não é um documento que visa demonstrar um fato ou ato, mas uma manifestação do espírito criador de um autor. Entretanto, se alguém se apropriar de

\footnotetext{
${ }^{267}$ DINAMARCO, Cândido Rangel. Op. cit., v. 3, p. 659.

${ }^{268}$ Ibidem, p. 591. Itálicos no original.
} 
elementos criativos da obra com usurpação de paternidade e, sobretudo, do cerne da obra, a obra torna-se também um documento a ser levado em juízo juntamente com a obra supostamente plagiadora. Não se trata mais somente de duas criações do espírito independentes, mas de dois documentos que têm o fito de mostrar uma violação de direito de autor: o plágio.

Por sua vez, se a obra supostamente plagiada for inédita, como ficaria a questão do ineditismo em juízo? O ineditismo não terminaria se uma obra inédita supostamente plagiada fosse apresentada em juízo, uma vez que o juiz pode decretar o segredo de justiça, consoante o inciso I do art. 155 do Código de Processo Civil. Há um interesse público no respeito ao direito ao inédito, um direito inalienável e irrenunciável. Por outro lado, não terminaria o ineditismo, pois os auxiliares do juiz têm o dever de sigilo. De igual modo, a suposta vítima de plágio ingressa em juízo por não ter outro meio de solução de conflito.

O meio de prova mais seguido para a verificação do plágio é a perícia, em especial o exame.

A perícia, consoante João Batista Lopes, é um meio de prova dispendioso para as partes, bem como retardador da prestação jurisdicional, sendo admitida em questões técnicas ou especializadas. $^{269}$

Com efeito, os custos de uma perícia desencorajam as partes a provar os fatos alegados, pois cabem à parte que requereu o exame ou, se ambas, ao autor da ação, como dispõe o art. 33 do Código de Processo Civil. A iniciativa de João Batista Lopes de submeter a questão à Comissão de Reforma do Código de Processo Civil, em 1996, nos parece razoável, uma vez que a remuneração do perito seria coberta pelo produto da arrecadação das custas judiciais. ${ }^{270}$ Isto não oneraria excessivamente as partes dependentes de prova pericial.

Resta ao juiz avaliar a pertinência da produção de prova pericial. No caso de plágio de obra literária, que pode ser um romance, uma coletânea ou uma obra de poesia, bem

\footnotetext{
${ }^{269}$ LOPES, João Batista. A prova no Direito Processual Civil. 3. ed., São Paulo: Revista dos Tribunais, 2007, p. 131.

${ }^{270}$ Ibidem, p. 137.
} 
pode o juiz dispensar a produção de prova pericial, seguindo os critérios da legislação e da doutrina autoralistas no exame do confronto das obras. No entanto, os juízes, na sua maioria, não dispõem de tempo para se dedicar ao exame acurado do plágio, sendo mais seguro confiar o exame das obras supostamente plagiada e supostamente plagiadora a um especialista ou técnico no assunto.

Vale ressaltar que o perito, como explica João Carlos Pestana de Aguiar, é:

pessoa que adquiriu seus conhecimentos especializados através de estudos em estabelecimentos de ensino superior apropriados, recebendo diploma legal que o habilite à prática da profissão. Só excepcionalmente, à falta de técnico habilitado no lugar, ou não sendo a profissão reconhecida, se recorrerá ao prático. ${ }^{271}$

O juiz, ao nomear um perito do juízo para examinar o plágio, deverá considerar a formação do profissional da área sobre que versam as obras supostamente plagiada e supostamente plagiadora. Por exemplo, um bacharel em Filosofia para examinar duas obras em confronto dentro da matéria. O perito conhecedor da área cujas obras versam pode excluir os elementos comuns, como opiniões comuns de uma escola de pensamento que não são contribuições pessoais de cada autor.

Para melhor exame do plágio, não basta a análise somente das obras supostamente plagiada e supostamente plagiadora. O ideal, se possível, é perquirir os traços pessoais de cada autor em outras obras publicadas anteriormente pelos mesmos autores. Trata-se de tarefa demorada e dispendiosa. Contudo, a análise de outras obras, além das examinadas, pode contribuir para alcançar uma conclusão melhor.

Ademais, uma acusação de plágio incute no espírito de qualquer pessoa, incluindo o perito, um prejulgamento. O perito não deve examinar a obra supostamente plagiada como se realmente o fosse, devendo ser imparcial na identificação do plágio. Nesse sentido, o perito deve examinar cada obra respeitando os traços pessoais de cada autor presentes em cada obra. As semelhanças pessoais em cada obra demonstrarão se há ou não plágio.

A elaboração atenta de quesitos, tanto pelas partes como pelo juiz, contribuirá para

${ }^{271}$ AGUIAR, João Carlos Pestana de. Comentários ao Código de Processo Civil. São Paulo: Revista dos Tribunais, 1974, v. 4, p. 326. 
o bom funcionamento do perito. O exame pericial, em especial do plágio, não é uma tarefa fácil, não sendo mensurado apenas pela extensão, mas também pela extração de poucos elementos criativos presentes na obra supostamente plagiadora, como ocorre no plágio parcial. Assim, a observância dos conceitos formulados pela doutrina autoralista, v.g., a originalidade, o não ingresso no mérito das obras, as teorias de identificação da obra, o rol de criações não protegida pelo Direito de Autor etc. podem ser determinantes na identificação do plágio.

No entanto, sobretudo em obras literárias, os peritos formados em Letras muitas vezes seguem critérios teóricos de sua especialidade, não seguindo ou desconhecendo os conceitos formados paulatinamente pelo Direito de Autor. Não desprezamos o conhecimento haurido no curso de Letras, contudo devemos priorizar a doutrina e jurisprudência autoralistas. Por isso, a boa formulação de quesitos de acordo com o Direito de Autor pode melhorar a compreensão da geralmente nebulosa identificação de plágio.

Um perito com formação em Letras, v.g., poderá fundamentar o seu parecer em critérios estranhos ao Direito de Autor. Um conceito de Semiótica usado quase indiscriminadamente como argumento de defesa em acusações de plágio literário é o de intertextualidade. ${ }^{272}$

\footnotetext{
${ }^{272} \mathrm{O}$ conceito de intertextualidade foi proposto por Julia Kristeva. Segundo esta autora, há um diálogo entre três elementos no conceito de intertextualidade: "Essas três dimensões são: o sujeito da escrita, o destinatário e os textos exteriores (três elementos em diálogo). O status da palavra se define então a) horizontalmente: a palavra no texto pertence ao sujeito da escrita e ao destinatário, e b) verticalmente: a palavra no texto é orientada em direção ao corpus literário anterior ou sincrônico. Mas no universo discursivo do livro, o destinatário está incluído no próprio discurso. Ele está fundido com este outro discurso (este outro livro) em relação ao escritor que escreve seu próprio texto; de maneira que o eixo horizontal (sujeito-destinatário) e o eixo vertical (texto-contexto) coincidem ao desvendar um fato maior: a palavra (o texto) é um cruzamento de palavras (de textos) onde lemos, ao menos, uma outra palavra (texto).”. (KRISTEVA, Julia. $\Sigma \boldsymbol{\eta} \mu \varepsilon \mathbf{\omega} \omega \tau \iota \chi \boldsymbol{\eta}$ [Sèméiôtikè]: Recherches pour une Sémanalyse. Paris: Seuil, 1969, p. 84, tradução nossa.) No original: "Ces trois dimension sont: le sujet de l'écriture, le destinataire et les textes extérieurs (trois éléments en dialogue). Le status du mot se définit alors a) horizontalment: le mot dans le texte appartient à la fois au sujet de l'écriture et au destinataire, et b) verticalment: le mot dans le texte est orienté vers le corpus littéraire antérieur ou syncronique. Mais dans l'univers discursif du livre, le destinataire est inclus uniquement en tant que discours lui-même. Il fusionne donc avec cet autre discours ( cet autre livre) par rapport auquel l'écrivain écrit son proper texte; de sorte que l'axe horizontal (sujet-destinataire) et l'axel vertical (textecontexte) coincidente pour dévoiler un fait majeur: le mot (le texte) est um croisement de mots (de textes) où on lit au moins un autre mot (texte)." Vale destacar que o perito em processo sobre plágio literário, em julgado do Tribunal de Justiça do Rio de Janeiro, valeu-se do conceito de intercontextualidade para fundamentar o seu parecer. O conceito de intercontextualidade, transcrito no v. acórdão é: "situação em que o autor se aproveita da tradução ou até mesmo das obras de seus contemporâneos para desenvolver a sua própria". (RIO DE JANEIRO (Estado). Tribunal de Justiça. Apelação n. 00073419-12.2004.8.19.0001. Apelante: Denise da Costa. Apelados: Diler \& Associados Ltda. e outro, Flávio de Souza e outro e Globo Comunicações Participações S/A. Relator: Des. Edson Vasconcelos. 17ª Câmara Cível. Rio de Janeiro, 10 de
} 
Por outro lado, os programas de computador destinados a encontrar o plágio se limitam a verificar palavras ou termos idênticos na forma externa ou expressão, não protegidas pelo Direito de Autor. No entanto, esses programas de computador nos auxiliam a buscar transcrições com omissão de citação em trabalhos pesquisados na Internet. ${ }^{273}$

Enfim, não há como estabelecer um critério preciso e definitivo na identificação do plágio. Por ser um fato, o exame de cada caso mostrará a ocorrência da violação de direito de autor.

\subsection{Valoração das provas}

Após a colheita das provas, cabe a juiz avaliar e decidir. Como dissemos acima, no caso do plágio, as provas mais importantes são a documental e a pericial.

No sistema processual brasileiro vige o princípio do convencimento racional, consagrado no art. 131 do Código de Processo Civil. O juiz deve decidir a partir das provas e argumentos apresentados no processo.

Dissemos anteriormente que o Direito de Autor não ingressa no mérito das obras, isto é, para que uma obra seja protegida pelo Direito de Autor não importa o seu valor intrínseco. Vale lembrar também que a proteção autoral é automática, independendo de exame prévio, como ocorre com as invenções e os modelos de utilidade no Direito Industrial. Lembremos que no quarto capítulo deste trabalho, mencionamos a análise que Caroline Carreau fez da jurisprudência autoral francesa, em que encontrou muitas decisões nas quais o mérito das obras foi considerado.

Ressalta-se que o juiz não deve se tornar um crítico literário, julgando o plágio de acordo com as suas preferências e gostos pessoais. No entanto, o juiz é um homem comum

novembro de 2010. Disponível em: <http://webserver2.tjrj.jus.br/ejud/ConsultaProcesso.aspx? $\mathrm{N}=201000149959$ >. Acesso em: 05 out. 2012.

${ }^{273}$ O sítio eletrônico "Portal da escrita científica", do Campus de São Carlos da Universidade de São Paulo, disponibiliza alguns programas "anti-plágio". (UNIVERSIDADE DE SÃO PAULO. Portal da Escrita Científica do Campus de São Carlos. Software Anti-plágio. Disponível em: <http:// www.escritacientifica.sc.usp.br/anti-plagio>. Acesso em 20 dez. 2012). 
passível de ser influenciado por opiniões tanto da crítica especializada como de notícias veiculadas pela imprensa.

Nessa linha de ideias, João Batista Lopes frisa que o juiz não é um autômato ao aplicar a lei, não estando imune a ideologias. Porém, o juiz, ao ser imparcial, não deve favorecer uma das partes em litígio, mas estar sensível aos problemas de seu tempo. ${ }^{274}$

Não é tarefa fácil identificar o plágio, bem como julgar sem estar imune às preferências pessoais ou influências. O perito, ao elaborar o seu laudo, também não está restrito aos quesitos apresentados pelo juiz e pelas partes. Como vimos acima, o perito pode seguir critérios alheios ao Direito de Autor por preferências de metodologia.

Por outro lado, os critérios do Direito de Autor são menos precisos, por tutelarem criações estéticas, em comparação aos do Direito Industrial, que tutela criações técnicas. É da própria natureza do Direito de Autor ter um grau maior de subjetividade por tutelar as criações estéticas. Vale lembrar que o conceito de originalidade, conforme Pierre-Yves Gautier, é um "vício fundamental” da matéria. ${ }^{275}$ Desse modo, não há como estabelecer uma definição ou exemplificar o que é o plágio.

Logo, o juiz deve ser prudente ao avaliar o conjunto probatório em caso de plágio. Por ser um fato, cada caso tem a sua particularidade, tanto em relação às partes quanto em relação ao objeto. O laudo pericial deverá refletir, mesmo que sem muita precisão, a eventual extração de elementos criativos da obra supostamente plagiada e da obra supostamente plagiadora.

${ }^{274}$ LOPES, João Batista. Op. cit., p. 200-201.

${ }^{275}$ GAUTIER, Pierre-Yves. Op. cit., p. 49. 


\section{CONCLUSÃO}

O plágio é um tema polêmico e impreciso. Por isso, enseja acusações em diversos meios e sobre qualquer gênero de obra.

Procuramos, no presente trabalho, abordar a questão do plágio, em especial em obra literária, seguindo o Direito de Autor.

Vimos no primeiro capítulo que o plágio, desde a Antiguidade, é um ato moralmente reprovado. O Direito de Autor, como conhecemos hoje, tem sua origem na Lei Le Chapelier. Analisamos o desenvolvimento do Direito de Autor na doutrina, bem como na legislação estrangeira e nacional.

No Brasil, a Lei de 11 de agosto de 1827, lei criadora dos cursos jurídicos, foi a primeira a dispor de forma expressa sobre o Direito de Autor. Em seguida, o Código Criminal do Império trouxe disposição sobre o Direito de Autor no capítulo dedicado ao furto. Com o advento da República, a primeira Constituição do novo regime dispôs sobre o Direito de Autor. O Código Penal de 1890 trouxe algumas disposições sobre o Direito de Autor. Destacamos que o Código Penal de 1890, no parágrafo único do art. 350, procurou limitar as violações ao direito de autor de modo casuístico sob a rubrica de "contrafação". Por seu turno, a Lei n. 496, de $01^{\circ}$ de agosto de 1898 - Lei Medeiros de Albuquerque veio a regulamentar em detalhes o Direito de Autor. Da mesma forma do Código Penal de 1890, a Lei n. 496/1898, no art. 19, definiu contrafação como violação ao direito de autor de modo genérico. A Lei n. 496/1898 ainda determinou a formalidade do registro da obra para a proteção dos direitos do autor (art. 13).

O Código Civil de 1916 regulamentou o Direito de Autor e os contratos de edição e representação dramática no Livro do Direito das Obrigações, enquanto o restante da matéria autoral foi tratado no Livro do Direito das Coisas. No que diz respeito às formalidades, o Código Civil de 1916 adotou o sistema de proteção automática, sistema até hoje vigente em nosso país e que, a nosso ver, é melhor por não restringir a liberdade criativa. 
Salienta-se a disposição constante no art. 667 do CC/1916, a cessão de direito à paternidade. Pensamos que é uma anomalia no sistema autoral, pois um direito moral de autor não pode ser cedido, principalmente no fito de enganar o público sobre o verdadeiro criador de obra, como ocorre no plágio. De fato, há um risco na atividade editorial que propicia a publicação de obras de autores renomados em detrimento de novos talentos desconhecidos. Vale lembrar que a cessão de direito à paternidade não constava na redação original do Anteprojeto de Código Civil, sendo uma infeliz intervenção legislativa no trâmite do Projeto de Código Civil. Em nenhum momento houve uma disposição expressa sobre o plágio.

No segundo capítulo abordamos a legislação revogada, vigente e projetos de lei.

A Lei n. 5.988/1973, revogada pela Lei n. 9.610/1998, veio a regulamentar o Direito de Autor e Conexos em mais detalhes que as leis anteriores. O sentido de contrafação, de gênero de violação de Direito de Autor, passa a se restringir à reprodução não autorizada, ainda mantida pela Lei n. 9.610/1998. Frisa-se que em ambos os diplomas legislativos não há uma definição de plágio, como há de contrafação. Cremos que a incerteza e a imprecisão sobre o plágio enseja certa prudência da parte do legislador ao não positivá-lo, posto que é mais uma violação aos direitos morais de autor que uma violação aos direitos patrimoniais de autor (como a contrafação).

Por outro lado, o Código Penal de 1940, ainda vigente, depois de ter passado por muitas alterações, tipifica o crime de violação aos direitos autorais em norma penal em branco, isto é, uma norma penal dependente de outra norma jurídica para a sua interpretação e aplicação. Pensamos ser uma boa opção legislativa, pois o Direito de Autor é matéria específica, e uma norma penal em branco não exclui do âmbito de sua incidência nenhuma violação autoral. Além disso, cremos que o tabelamento de violações aos direitos de autor não seja uma boa via porque limita demasiadamente a aplicação da norma penal.

Ademais, analisamos o Anteprojeto de Lei Autoral de iniciativa do Ministério da Cultura e o Projeto de Lei n. 236/2012, que visa alterar o Código Penal de 1940, em trâmite no Senado Federal. O Anteprojeto de Lei Autoral não altera a definição da lei vigente sobre contrafação, assim como não introduz um dispositivo sobre o plágio. Entretanto, o Projeto de Lei n. 236/2012 traz um tipo penal denominado "plágio 
intelectual", no $\S 1^{\circ}$ do art. 172. Vimos que a legislação brasileira em nenhum momento tipificou a conduta ilícita do plágio. Não consideramos apropriado legislar sobre o plágio, uma vez que é um fato complexo que envolve a criação intelectual. Além disso, a redação do crime de "plágio intelectual" enfatiza a usurpação de paternidade, não dizendo nada sobre o plágio parcial ou sobre a extração indevida dos elementos criativos da obra. Dizemos mais uma vez que preferimos uma norma penal em branco, como dispõe o art. 184 do Código Penal vigente.

No âmbito internacional, a Convenção de Berna é o diploma fundamental na regulamentação do Direito de Autor. O art. 6 bis da Convenção de Berna, embora disponha sobre o direito de reivindicar a paternidade da obra e sobre o direito à integridade, cremos que seja aplicável aos casos de plágio, posto que o plágio é antes de tudo uma violação aos direitos morais de autor. Por seu turno, a Convenção Universal sobre o Direito de Autor não tem disposição expressa sobre os direitos morais de autor como a Convenção de Berna, sendo que trata de tais direitos de forma implícita - na obrigatoriedade do nome do autor e título da obra estampado em exemplares de traduções na alínea "e" do art. 50. Enfim, o Anexo 1C do Acordo Constitutivo da Organização Mundial do Comércio, o Acordo sobre Aspectos dos Direitos de Propriedade Intelectual Relacionados ao Comércio (TRIPS/AADPIC), exclui de modo expresso a aplicação do art. 6 bis da Convenção de Berna, no $\S 1^{\circ}$ do art. $9^{\circ}$, ressaltando o caráter econômico na circulação internacional das obras. Não podemos olvidar que todos os tratados internacionais a que acabamos de referir foram recepcionados pelo nosso ordenamento jurídico.

A lei autoral peruana revogada dispunha melhor sobre o plágio que o tipo penal denominado "plágio intelectual", pois inclui o plágio parcial e o plágio mascarado, sendo este o plágio encoberto por alterações efetuadas pelo plagiador de modo a dissimular o ato ilícito.

No quarto capítulo abordamos as teorias da doutrina autoralista sobre a identificação dos elementos tuteláveis nas obras. As três teorias — teoria da forma externa, forma interna e conteúdo, de Kohler; teoria da identidade de representação, de Eduardo Piola Caselli, e a teoria da ideia, composição e expressão, de Henri Desbois — buscam identificar os elementos passíveis de proteção nas obras, mas sem traçar um limite preciso. Há em comum entre as três teorias a tutela de elementos que demonstram a pessoalidade 
do autor. Por seu turno, Eduardo Piola Caselli procura maior objetividade ao identificar os elementos protegidos na obra de maneira orgânica, porém não destacando separadamente os elementos componentes na obra. Cremos que a imprecisão nos limites dos elementos tuteláveis se deve à própria natureza das criações estéticas, providas de alto grau de subjetividade.

Por outro lado, vimos o conceito de originalidade em oposição ao de banalidade. O conceito de originalidade, nas palavras de Pierre-Yves Gautier, é o "vício fundamental" do Direito de Autor, sendo um critério consagrado pela doutrina autoralista. Devemos excluir todo elemento comum ao perscrutar o tratamento pessoal do autor numa obra, o que não é uma tarefa fácil por ser um conceito subjetivo. Vimos também que o conceito de novidade não auxilia o entendimento sobre a proteção da obra, sendo um conceito mais apropriado para a proteção das criações técnicas, mais objetivas que as criações estéticas.

Não há mais razão para inserir o plágio no conceito de contrafação, pois em nossa legislação a definição de contrafação realça o seu aspecto pecuniário, ao contrário do plágio, no qual a tônica está na ofensa aos direitos morais de autor.

Pensamos que o plágio ofende os direitos morais de autor, em especial os direitos à paternidade e à integridade. Este direito é violado na extração de elementos criativos de obra preexistente pelo plagiador, enquanto que o direito à paternidade é violado na usurpação. Assim, não basta somente a usurpação de paternidade para haver o plágio, como ocorre na cópia servil, mas também a utilização indevida de elementos pessoais do autor. Não pretendemos dizer que a cópia servil com usurpação de paternidade não seja uma violação ao direito de autor, porém é uma violação diversa do plágio.

A publicação da obra plagiadora ou a sua comunicação ao público é essencial para a configuração do ilícito de plágio. Cremos que os esforços do plagiador têm o fito de enganar a fé pública. Nesse sentido, a publicidade pode ser verificada tanto no denominado "plágio intelectual” como na definição constante na lei autoral peruana revogada. Também o dolo é essencial para a ocorrência de plágio. É preciso a intenção de usurpar a paternidade e extrair os elementos criativos de obra de outrem.

No que tange às obras literárias, enfatizamos que o estilo não é protegido pelo 
Direito de Autor, o que pode ser verificado na paródia, no pastiche e na paráfrase, usos não violadores de direito de autor. No entanto, tais usos podem ensejar o plágio ou servirem na sua ocultação. Salienta-se que o estilo está, de acordo com as teorias de identificação dos elementos protegidos na obra, na forma externa ou na expressão, elementos por si sós não tuteláveis porque são desprovidos de um traço pessoal do autor.

Por ser antes de tudo um fato ilícito complexo, não há como dizer com certeza o que é o plágio mediante exemplos. Por isso, faz-se mister a procura dos elementos criativos na obra supostamente plagiada e na obra supostamente plagiadora, procura esta que será procedida em juízo ou em outra instância no confronto entre ambas. Sugerimos no exame do plágio literário, além do confronto entre as obras supostamente plagiada e supostamente plagiadora, a leitura cuidadosa de obras publicadas anteriormente pela vítima e pelo suposto plagiador, no escopo de identificar melhor o tratamento pessoal de cada um.

Enfim, o plágio, pela natureza subjetiva das obras intelectuais, não é de fácil identificação. Cabe ao examinador do caso de plágio um espírito livre de paixões, predileções e, acima de tudo, prejulgamento sobre a imputação de plágio, o que nem sempre é possível. Desse modo, há o risco de ingressar no mérito da obra. 


\section{REFERÊNCIAS}

AGUIAR, João Carlos Pestana de. Comentários ao Código de Processo Civil. São Paulo: Revista dos Tribunais, 1974.

ALGARDI, Zara Olivia. Il plagio letterario e il carattere creativo dell'opera. Milano: Giuffrè, 1966.

ARNS, Paulo Evaristo. A técnica do livro segundo São Jerônimo. Tradução Cleone Augusto Rodrigues. 2 ed. São Paulo: Cosac Naify, 2007.

ASCARELLI, Tullio. Teoria della concorrenza e dei beni immateriali. 3. ed. Milano: Giuffrè, 1960.

ASCENSÃO, José de Oliveira. Direito Autoral. 2. ed., Rio de Janeiro: Renovar, 2007.

BEVILACQUA, Clóvis. Direito das coisas. Rio de Janeiro: Freitas Bastos, 1941. Edição fac-símile. Rio de Janeiro: Rio, 1976.

BEVILACQUA, Clóvis. Direito das obrigações. 6. ed., Rio de Janeiro: Francisco Alves, 1945. Revisão e atualização Achilles Bevilacqua.

BITTAR, Carlos Alberto. Direito de Autor. 4. ed., Rio de Janeiro: Forense Universitária, 2008. Revisão, ampliação e atualização Eduardo C. B. Bittar: conforme a Lei n. 9.610, de 19 de fevereiro de 1998, e de acordo com o novo Código Civil.

BITTAR, Carlos Alberto; BITTAR FILHO, Carlos Alberto. Tutela dos direitos da personalidade e dos direitos autorais nas atividades empresariais. 2. ed., São Paulo: Revista dos Tribunais, 2002. Revisão e atualização Carlos Alberto Bittar Filho.

BONAMORE, Daniele. Il plagio del titolo delle "opere dell'ingegno" nella dogmatica del Diritto d'Autore. Milano: Giuffrè, 2011.

BRASIL. Câmara dos Deputados. Projeto de Lei n. 5.430/1990. Disponível em: <http://www.camara.gov.br/proposicoesWeb/fichadetramitacao?idProposicao=227532>. Acesso em: 20 out. 2011.

BRASIL. Código Civil brasileiro. Rio de Janeiro: Jacintho Ribeiro dos Santos, 1916. Edição precedida de síntese histórica e crítica de Paulo Lacerda de Almeida. 
BRASIL. Código Criminal do Império. Disponível em <http://www.planalto.gov.br/ ccivil_03/Leis/LIM/LIM-16-12-1830.htm>. Acesso em: 06 jul. 2011.

BRASIL. Códigos 4 em 1 Saraiva: Civil, Comercial, Processo Civil e Constituição Federal. 8. ed. São Paulo: Saraiva, 2012. Obra coletiva de autoria da Editora Saraiva com a colaboração de Luiz Roberto Curia, Livia Céspedes e Juliana Nicolleti.

BRASIL. Código Penal: Decreto n. 847, de 11 de outubro de 1890. Disponível em: <http://www6.senado.gov.br/legislacao/ListaPublicacoes.action?id=66049>. Acesso em: 05 set. 2011.

BRASIL. Código Penal: Decreto-Lei n. 2.848, de 07 de dezembro de 1940. Disponível em: <http://www6.senado.gov.br/legislacao/ListaPublicacoes.action?id=102343\&tipo Documento=DEL\&tipoTexto=PUB $>$. Acesso em 30 set. 2011.

BRASIL. Coletânea de Legislação de Comunicação Social. 7. ed. São Paulo: RT, 2010. Revisão e atualização Marcos Alberto Sant’Anna Bitelli.

BRASIL. Constituição da República dos Estados Unidos do Brasil 1891. Disponível em: <http://www.planalto.gov.br/ccivil_03/constituicao/Constitui\%C3\%A7ao91.htm>. Acesso em: 06 jul. 2011.

BRASIL. Constituição Política do Império do Brasil. Disponível em: <http://www.planalto.gov.br/ccivil_03/constituicao/constituicao24.htm>. Acesso em: 06 jul. 2011.

BRASIL. Decreto de 29 de outubro de 1810. Índice de Leis Históricas. Disponível em: <http://www.planalto.gov.br/CCIVIL_03/revista/Rev_69/Decreto.htm>. Acesso em: 06 jul. 2011.

BRASIL. Decreto do Príncipe Regente D. João, de 13 de maio de 1808. Disponível em:<http://www.planalto.gov.br/ccivil_03/revista/Rev_27/dim1305003.htm>. Acesso em: 06 jul. 2011.

BRASIL. Decreto do Príncipe Regente D. João, de 29 de outubro de 1810. Disponível em: <http://www.planalto.gov.br/CCIVIL_03/revista/Rev_69/Decreto.htm>. Acesso em: 06 jul. 2011.

BRASIL. Decreto n. 1.355, de 30 de setembro de 1994. Disponível em: <http://www.planalto.gov.br/ccivil_03/decreto/1990-1994/anexo/and1355-94.pdf>. Acesso em 17 ago. 2012. 
BRASIL. Decreto n. 6.583, de 29 de setembro de 2009. Disponível em: <http://www.planalto.gov.br/ccivil_03/_Ato2007-2010/2008/Decreto/D6583.htm>. Acesso em: 06 dez. 2012.

BRASIL. Lei n. 10.695, de $\mathbf{1}^{\mathbf{0}}$ de julho de 2003. Disponível em: < http://www6.senado.gov.br/legislacao/ListaPublicacoes.action?id=236928\&tipoDocument $\mathrm{o}=$ LEI\&tipoTexto=PUB $>$ Acessado em 12 out. 2011.

BRASIL. Lei n. 496, de $\mathbf{1}^{\circ}$ de agosto de 1898 . Disponível em: <http://www6.senado.gov.br/legislacao/ListaPublicacoes.action?id=60815\&tipoDocument o=LEI\&tipoTexto=PUB $>$. Acesso em: 06 jul. 2011.

BRASIL. Lei n. 5.988, de 14 de dezembro de 1973. Disponível em: <http://www6.senado.gov.br/legislacao/ListaPublicacoes.action?id=122027\&tipoDocumen to=LEI\&tipoTexto=PUB $>$. Acesso em: 06 jul. 2011.

BRASIL. Lei n. 6.895, de 17 de dezembro de 1980. Disponível em: <http://www6.senado.gov.br/legislacao/ListaPublicacoes.action?id=126454\&tipoDocumen to=LEI\&tipoTexto=PUB $>$. Acesso em 11 out. 2011.

BRASIL. Ministério da Cultura. Acessoria de Comunicação. Direito Autoral: Anteprojeto seguiu para Casa Civil depois de incorporar contribuições da sociedade. 9 jan. 2012. Disponível em: <http://www.cultura.gov.br/site/2012/01/09/134950>. Acesso em: 12 jan. 2012.

BRASIL. Ministério da Cultura. Anteprojeto de Lei de Modernização da Lei Autoral: tabela comparativa das propostas de revisão da Lei de Direito Autoral. Disponível em: <http://www.cultura.gov.br/site/wp-content/uploads/2011/04/LDA_tabela_compara_versoes_PosGIPI.pdf >. Acesso em: 16 out. 2011.

BRASIL. Projeto de Lei n. 5.430, de 1990. Diário do Congresso Nacional da República Federativa do Brasil, seção 1, ano 45, n. 84. Brasília, DF, 7 ago. 1990, p. 8.720-8.727.

BRASIL. Projeto de Lei n. 5.430, de 1990. Disponível em: <http://www.camara.gov.br/proposicoesWeb/fichadetramitacao?idProposicao=227532>. Acesso em: 20 out. 2011.

BRASIL. Senado Federal. Relatório Final da Comissão de Juristas para a Elaboração de Anteprojeto de Código Penal: Projeto de Lei n. 236, de 2012. 480 fls. Disponível em: <http://www12.senado.gov.br/noticias/Arquivos/2012/06/pdf-veja-aqui-o-anteprojeto-dacomissao-especial-de-juristas >. Acesso em: 02 ago. 2012. 
CALMELS, Édouard. De la propriété et de la contrefaçon des oeuvres de l'intelligence. Paris: Çosse, 1856. Disponível em: <http://gallica.bnf.fr/ark:/12148/bpt6k58585097>. Acesso em: 06 jul. 2011.

CARREAU, Caroline. Mérite et Droit d’Auteur. Paris: LGDJ, 1981.

CASELLI, Eduardo Piola. Trattato del Diritto di Autore. 2. ed. Torino: Unione Tipografico-Editrice Torinese, 1927.

CERQUEIRA, João da Gama. Tratado da Propriedade Industrial. Rio de Janeiro: Lumen Júris, 2010, v. 1, parte 1. Atualização Newton Silveira e Denis Borges Barbosa.

CHAVES, Antônio. Plágio. In: Revista de Informação Legislativa. Brasília: Senado Federal, v. 20, n. 77. p. 403-424, jan./mar. 1983. Disponível em: <http://www2.senado.gov.br/bdsf/item/id/181420>. Acesso em: 6 jul. 2011.

CHINELLATO, Silmara Juny de Abreu. Direito de autor e direitos da personalidade: reflexões à luz do Código Civil. 2009. 272 p. Tese (Concurso para Professor Titular do Departamento de Direito Civil) - Faculdade de Direito, Universidade de São Paulo, 2008.

CHINELLATO, Silmara Juny de Abreu. Notas sobre plágio e autoplágio. In: Revista do Instituto dos Advogados de São Paulo. São Paulo: Revista dos Tribunais, n. 29, p. 305 328, jan./jun. 2012.

COSTA JÚNIOR, Paulo José da. Direito Penal Objetivo. 3. ed. Rio de Janeiro: Forense Universitária, 2003.

COSTA NETO, José Carlos. Direito Autoral no Brasil. 2. ed., São Paulo: FTD, 2008.

DE MATTIA, Fábio Maria. Do privilégio do editor ao aparecimento da propriedade literária e artística em fins do século XVIII. In: Revista de Informação Legislativa. Brasília: Senado Federal, v. 16, n. 63, p. 161-182, jul./set. 1979. Disponível em: <http://www2.senado.gov.br/bdsf/item/id/181148>. Acesso em: 06 jul. 2011.

DE MATTIA, Fábio Maria. O autor e o editor na obra gráfica. São Paulo: Saraiva, 1975.

DE SANCTIS, Vittorio Maria. I soggetti del Diritto d'Autore. 2. ed., Milano: Giuffrè, 2005.

DE SANCTIS, Vittorio Maria. Il carattere creativo delle opere dell'ingegno. Milano: Giuffrè, 1971. 
DESBOIS, Henri. Le droit d'auteur en france. Paris: Dalloz, 1966.

DICIONÁRIO ELETRÔNICO Houaiss da Língua Portuguesa .Versão 2009.4. Rio de Janeiro: Objetiva, 2009.

DINAMARCO, Cândido Rangel. Instituições de Direito Processual Civil. 6. ed., São Paulo: Malheiros, 2009.

DOCK, Marie-Claude. Contribution historique à l'étude des Droits d'Auteur. Paris: LGDJ, 1962.

DUVAL, Hermano. Violações dos direitos autorais. Rio de Janeiro: Borsoi, 1968.

ESPANHA. Ley Orgánica 10/1995, de 23 de noviembre, del Código Penal. Disponível em: <http://www.boe.es/buscar/act.php?id=BOE-A-1995-25444\&b=372\&tn=1\&p= 20100623\#a270>. Acesso em 18 ago. 2012.

FRANÇA, Rubens Limongi (Coord.). Enciclopédia Saraiva do Direito. São Paulo: Saraiva, 1977, v. 19; v. 20.

FRANÇA. Code de la Propriété Intellectuelle. Disponível em: <http://www.legifrance.gouv.fr/telecharger_pdf.do?cidTexte=LEGITEXT000006069414>. Acesso em 10 jul. 2012.

FRANÇON, André. La propriété littéraire et artistique en grande-bretagne et aux États-Únis. Paris: Arthur Rousseau, 1955.

GARCIA, Balmes Vega. Contrafação de patentes. São Paulo: LTr, 2004.

GASTAMBIDE, Adrien-Joseph. Traité théorique et pratique des contrefaçons en tous genres. Paris: Legrand et Descauriet, 1837. Disponível em: <http://gallica.bnf.fr/ark:/12148/bpt6k5727743k>. Acesso em: 06 jul. 2011.

GAUTIER, Pierre-Yves. Propriété littéraire et artistique. 7. ed., Paris: PUF, 2010.

GLOBO COMUNICAÇÃO PARTICIPAÇÕES S/A. Bom Dia Brasil. Falsas citações, atribuídas a grandes autores, circulam na internet. São Paulo, 29 nov. 2011. Disponível em: <http://g1.globo.com/bom-dia-brasil/noticia/2011/11/falsas-citacoes-atribuidasgrandes-autores-circulam-na-internet.html>. Acesso em 30 nov. 2011. 
GRECO, Paolo; VERCELLONE, Paolo. I diritti sulle opere dell'ingegno. In: Trattato di Diritto Civile italiano. Torino: Unione Tipografico-Editrice Torinese, 1974, v. 11, t. 3.

HUARD, Gustave. Traité de la propriété intellectuelle. Paris: Marchal e Billard, 1903. Disponível em: <http://gallica.bnf.fr/ark:/12148/bpt6k5459737k>. Acesso em: 06 jul. 2011.

JARACH, Giorgio. Manuale del Diritto d'Autore. Milano: Mursia, 1968.

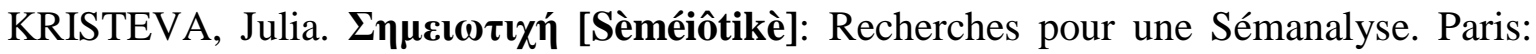
Seuil, 1969.

LE GOFF, Jacques. Les intellectuels au moyen âge. Paris: Seuil, 2000.

LIPSZYC, Delia. Derecho de autor y derechos conexos. Reimpresión inalterada de la edición de 1993. Buenos Aires: UNESCO; CERLALC; ZAVALIA, 2001.

LOPES, João Batista. A prova no Direito Processual Civil. 3. ed., São Paulo: Revista dos Tribunais, 2007.

LUCAS, André; LUCAS, Henri-Jacques. Traité de la propriété littéraire \& artistique. 3 ed., Paris: LITEC, 2006.

LUCAS-SCHOETTER, Agnès. Droit moral et droits de la personalité: étude de droit comparé français et allemand. Aix-en-Provence: Presses Universitaire d'Aix-Marseille, 2002, t. 1.

MORATO, Antonio Carlos. Direito de Autor em obra coletiva. São Paulo: Saraiva, 2007.

PASSOS, José Joaquim Calmon de. Comentários ao Código de Processo Civil. Rio de Janeiro: Forense, 1974.

PAULA BAPTISTA, Francisco de. Compêndio de hermenêutica jurídica. São Paulo: Saraiva, 1984, p. 12 e nota de rodapé 4, itálicos no original. Coleção "Clássicos do Direito brasileiro", v. 3, aos cuidados de Alcides Tomasetti Júnior. Tradução dos textos latinos Aloysio Surgik.

PERU. Ley n. 13.714: Ley de Derechos de Autor. Disponível em: <http:// www.congreso.gob.pe/ntley/Imagenes/Leyes/13714.pdf>. Acesso em: 17 ago. 2012. 
PERU. Ley n. 29.477/2009: Consolidación del Espectro Normativo Peruano. Disponível em: <http://www.congreso.gob.pe/ntley/Imagenes/Leyes/29477.pdf>. Acesso em: 17 ago. 2012.

PERU. Ley sobre el Derecho de Autor. Disponível em: <http://www.congreso.gob.pe/ntley/Imagenes/DecretosLegislativos/00822.pdf>. Acesso em 17 ago. 2012.

PIERANGELI, José Henrique. Códigos Penais do Brasil: evolução histórica. 2. ed. São Paulo: Revista dos Tribunais, 2001.

PONTES DE MIRANDA, Francisco Cavalcanti. Tratado de Direito Privado. Rio de Janeiro: Borsoi, 1956.

POUILLET, Eugène. Traité théorique et pratique de la propriété littéraire et artistique et du droit du répresentation. Paris: Imprimerie et Librerie Générale de Jurisprudence Marchal, Billard et Compagnie, 1879. Disponível em: <http://gallica.bnf.fr/ark:/12148/bpt6k5545122s>. Acesso em: 06 jul. 2011.

RENOUARD, Augustin-Charles. Traité des droits d'auteur, dans la literature: les sciences et les beaux-arts. Paris: Jules Renouard \& Cie, 1838. T. 1: Disponível em: <http://gallica.bnf.fr/ark:/12148/bpt6k5739469p>. T. 2: Disponível em: <http://gallica. bnf.fr/ark:/12148/bpt6k57394651>. Acesso em: 06 jul. 2011.

RIO DE JANEIRO (Estado). Tribunal de Justiça. Apelação n. 0007341912.2004.8.19.0001. Apelante: Denise da Costa. Apelados: Diler \& Associados Ltda. e outro, Flávio de Souza e outro e Globo Comunicações Participações S/A. Relator: Des. Edson Vasconcelos. 17 ${ }^{\mathrm{a}}$ Câmara Cível. Rio de Janeiro, 10 de novembro de 2010. Disponível em: <http://webserver2.tjrj.jus.br/ejud/ConsultaProcesso.aspx? $\mathrm{N}=$ 201000149959>. Acesso em: 05 out. 2012.

ROPPO, Enzo. O contrato. Tradução de Ana Coimbra e M. Januário C. Gomes. Coimbra: Almedina, 2009.

SANTOS, J. M. Carvalho. Código Civil brasileiro interpretado. 5. ed. Rio de Janeiro: Freitas Bastos, 1953.

SANTOS, N. P. Teixeira dos. O fazer literário e a lei. In: Revista de Informação Legislativa. Brasília: Senado Federal, v. 26, n. 102, abr./jun. 1989, p. 253. Disponível em: <http://www2.senado.gov.br/bdsf/item/id/181920>. Acesso em: 06 jul. 2011. 
SÃO PAUlO (Estado). Tribunal de Justiça. Apelação com Revisão n. 906828582.2006.8.26.0000. Apelantes: INEXH Instituto Nacional de Excelência Humana, Neil Hamilton Negrelli Júnior e João Paulo Kotzent. Apelados: João Paulo Kotzent, José Milton Kozent e INEXH Instituto Nacional de Excelência Humana. Relator: Des. Jesus Lofrano. $3^{\mathrm{a}}$ Câmara de Direito Privado. São Paulo, 22 fev. 2011. Disponível em: <https://esaj.tjsp.jus.br/cjsg/getArquivo.do?cdAcordao=4974859\&vlCaptcha=BtRde>. Acesso em: 05 out. 2012.

SILVA, Oscar José de Plácido e. Vocabulário jurídico. 15. ed. Rio de Janeiro: Forense, 1998. Atualizado por Nagib Slaib Filho e Geraldo Magela Alves.

SILVEIRA, Newton. Direito de Autor no design. 2. ed. São Paulo: Saraiva, 2012.

SOUZA, Rabindranath Valentino Aleixo Capelo de. O direito geral da personalidade. Coimbra: Coimbra, 1995.

TELLES JÚNIOR, Goffredo da Silva. Tratado da Conseqüência: curso de lógica formal. São Paulo: José Bushatsky, 1962.

TESTA, Ezio Spaziani. Le elaborazioni delle opere letterarie. In: Il Diritto di Autore, ano 30, n. 4, p. 543-616, out-dez, 1959.

TOLEDO, Francisco de Assis. Princípios básicos de Direito Penal. 5. ed. São Paulo: Saraiva, 1994.

UNIVERSIDADE DE SÃO PAULO. Portal da Escrita Científica do Campus de São Carlos. Software Anti-plágio. Disponível em: <http://www.escritacientifica.sc.usp.br/antiplagio>. Acesso em 20 dez. 2012.

VARNHAGEM, Francisco Adolfo de (Visconde de Porto Seguro). História geral do Brasil antes de sua separação e independência. Belo Horizonte: Itatiaia, 1981.

VILLALBA DÍAZ, Federico Andrés. ¿Quando el Plagio es Delito? 117 p. 2012. Dissertação (Mestrado em Direito Penal) - Faculdad de Derecho, Universidad de Palermo, Buenos Aires, 2012. 